\title{
TOWARDS A MACRO-PRUDENTIAL LEADING INDICATORS FRAMEWORK FOR MONITORING FINANCIAL VULNERABILITY
}

\author{
BISWA N. BHATTACHARYAY \\ CESIFO WORKING PAPER NO. 1015 \\ CATEGORY 10: EMPIRICAL AND THEORETICAL METHODS \\ August 2003
}
An electronic version of the paper may be downloaded
- from the SSRN website: www.SSRN.com
- from the CESifo website: www.CESifo.de




\title{
TOWARDS A MACRO-PRUDENTIAL LEADING INDICATORS FRAMEWORK FOR MONITORING FINANCIAL VULNERABILITY
}

\begin{abstract}
The 1997 Asian financial crisis has revealed the limitations of the current state of monetary and financial monitoring system in most Asian countries in comprehensively addressing financial and monetary problems and issues. This paper attempts to propose a macroprudential indicators (MPI) framework for monitoring vulnerability of financial markets. A literature survey on studies leading indicators has been presented. An illustrative and simple framework for analysis and interpretation of core set of 22 leading indicators (that were identified from 67 commonly agreed Asian Development Bank Indicators for selected AsiaPacific countries, namely Fiji, Indonesia, the Philippines, Thailand, Viet Nam, and Taiwan, Province of China ) has been presented using annual time-series data for the afore-mentioned countries. A correlation and volatility analysis of Thailand's annual and quarterly data (19942002) has also been performed in order to propose a simple methodology for constructing benchmarks for early warning signals and for developing a composite indicators. This above analysis carried out in this paper highlights the usefulness of MPIs as a tool for monitoring financial vulnerability.
\end{abstract}

JEL Code: F3, E0, G2.

\author{
Biswa N. Bhattacharyay \\ REMU \\ Asian Development Bank \\ 6 ADB Avenue, PO Box 789 \\ 0980 Manila \\ Philippines \\ Bbhattacharyay@adb.org
}

The views expressed in this paper are those of the author and do not necessarily reflect those of Asian Development Bank or CESifo. The author acknowledges the contribution of CESIfo and its staff for providing the necessary facilities and assistance for the preparation of the paper and Dr Gernot Nerb, Ifo Institute for his useful comments and assistance. 


\section{Introduction}

Several emerging market economies witnessed a large number of financial crisis in last decade which resulted with severe economic, social and political problems. On many occasions these financial crisis did not occur in a single country but had a contagion effect to other regional countries as well. For example, the Asian crisis of 1997 and the Latin American crisis of 1994 affected many countries in the region.

The Asian economic and financial crisis of 1997 has spawned a considerable body of analysis as to its origin, causes and resolution. Initially, the Asian crisis ignited the debate between the macrofundamental and the investor panic views. The Asian crisis differed from previous crises in several key respects. First, it was a capital account crisis, not a traditional current account crisis. Second, unlike other crises of confidence of the 1980s and 1990s, its root causes were structural: premature financial sector liberalization, weak governance, and policy mistakes in managing private capital flows. Another important characteristic of the crisis was that financial contagion tended to be mainly regional, requiring regional solutions. The consensus view favors the crisis-of-confidence-cum-structural weakness stance. It follows from this that monitoring the stability of financial markets, including asset markets, and devising early warning systems for predicting vulnerability in these markets would enable the authorities to deal better with potential crises and to develop more effective policy interventions to that end.

For monitoring vulnerability of financial markets, there is a need to define financial vulnerability. However, there is no universally accepted definition of what constitutes financial vulnerability. In general, typical characteristics of financial vulnerability include: (i) a significant deterioration in the public's confidence in financial institutions and markets, (ii) inability of the financial institutions to perform their core functions effectively, and (iii) significant economy wide spillover effects of the financial vulnerability.

Monitoring financial markets will involve detection of significant fragilities within the financial system which, in turn, may destabilize the financial system. This will also involve detection of potential disturbances emerging from outside the banking system. In this regard, there is a need to devise an appropriate early warning system for early detection of vulnerability of the financial system of a country. Leading indicator approach to monitoring financial vulnerability can be used in predicting turning points of vulnerability of financial system of a country. This approach is very useful because (i) early detection and timely recognition of financial vulnerability will allow policymakers to trigger preemptive policy measures to counter the vulnerability, 
financial supervisors to formulate and implement corrective measures, and businesses to adjust their business strategies; (ii) these indicators can give early warning signals which could not be obtained for standard macroeconomic models; and (iii) these are reliable and inexpensive forecasting tools.

\section{Objectives and Scope}

In order to develop measures of financial sector vulnerability and methods to analyze them, there is a need to develop appropriate indicators. However, there is no universally accepted set of indicators for monitoring financial markets. International Monetary Fund (IMF) has introduced Financial soundness indicators (FSIs) which are defined to be indicators compiled to monitor the health and soundness of financial institutions and markets, and of their corporate and household counterparts. FSIs include both aggregated microprudential indicators of the health of financial institutions and indicators that are representative of markets in which financial institutions operate. FSIs include indicators of the health of major clients of financial institutions, such as corporate and household sectors. On the other hand, Macroprudential indicators(MPIs) are relatively broad set of indicators. MPIs include both FSIs and other indicators, such as macroeconomic variables related to financial system vulnerabilty that support the assessment and monitoring of the strengths and vulnerabilities of financial systems, notably macroeconomic indicators(IMF, 2002).

The identification of an appropriate set of country-specific MPIs which are best suited to signaling a perilous financial or economic situation prior to a financial crisis will be useful the assessment and monitoring of the strengths and vulnerabilities of financial systems.

The Asian Development Bank (ADB), through a technical assistance project (RETA 5869), undertook the development of a system of commonly agreed MPI for selected developing member countries, namely Fiji, Indonesia, the Philippines, Thailand, Viet Nam, and Taiwan, Province of China. The main objectives of the project were to (i) identify and compile a set of FSI that can be used to monitor the asset and financial markets; (ii) strengthen the institutional capacity of central banks of the selected countries in compiling and analyzing relevant indicators for crisis monitoring; and (iii) to facilitate cross country comparisons of economic and financial vulnerability.

During the ADB's technical assistance project's inception workshop, six participating countries, namely Fiji, Indonesia, the Philippines, Thailand, Viet Nam, and Taiwan, Province of China, in consultation with representatives from International Monetary Fund (IMF), Bank for International Settlements (BIS), Deutsche Bundesbank, Bank of Japan, Bank of Korea, Australian Bureau of Statistics, United Nations Economic and Social Commission for Asia and the Pacific (UNESCAP), and ADB identified a set of 67 commonly agreed MPIs together with 43 additional MPIs with the following subsets of indicators:

a) External Debt and Financial Flows (8 indicators);

b) Money and Credit (17 indicators);

c) Banking (14 indicators);

d) Interest Rates (12 indicators); 
e) Stock Markets and Bonds (9 indicators);

f) Trade, Exchange Rate and International Reserve (10 indicators); and

g) Business Survey Data (9 indicators): mainly manufacturing but also Construction, Retail and Wholesale Trade and Services.

Bhattacharyay (2001) discussed the above indicators in detail.

The development of a system of commonly agreed ADB MPIs and additional country-specific MPIs in the Asia-Pacific region will facilitate monitoring economic and financial vulnerability of individual country as well as cross-country comparisons. However, there is a need for identifying a smaller and more operationally useful "core set" of indicators for properly periodic monitoring the financial system. This core set should have the following desirable characteristics: (i) These indicators should be leading or at least coincident indicators which will have early warning capability in order to prevent crisis; and (ii) For the short-term monitoring, the frequency of the availability of indicator should be monthly or quarterly.

Based on the above ADB MPIs, this study will propose a macro-prudential leading indicators framework for selected Asia-Pacific countries that could give early warning signals of vulnerability of financial markets, and support regular economic and financial monitoring. A literature review of leading MPI indicator framework proposed by academicians, researchers and supervisory organizations as well as international and regional organizations such as IMF and ADB, and studies on leading MPIs will be presented.

This paper will also present MPI/FSIs that have been used by selected developed and developing countries. This study will evaluate the performance of the above leading indicators for some countries in the Asia-Pacific region and propose an approach to analyze and interpret these leading indicators. A time-series analysis, namely, volatility and correlation analysis on the quarterly and an annual data (19942002) for leading indicators of Thailand will be performed to study the relationship among these indicators and their statistical behavior. This will help in further streamlining the core set of indicators and to propose a framework to construct a composite indicator based on correlation analysis and constructing threshold or benchmark for individual series based on volatility analysis. This is to be noted that the objective of this framework is not to predict crisis but to provide early warning for vulnerability. However, these indicators could be used for predicting crises using a suitable quantitative technique.

\section{Macroprudential Indicators}

The MPIs are a broad set of indicators that reflect the vulnerability of the financial and real economic systems to shocks. The importance of MPIs in any analysis, especially those carried out under a policy framework on vulnerability analysis, cannot be overemphasized in light of the extensive damage that currency, banking and financial crises could inflict on the economy.

The development of the MPI is rather recent, as indicated earlier. The tools that are utilized to quantify and qualify the soundness and vulnerabilities of the financial system are varied and can potentially be made as complex or sophisticated as 
needed. Depending on the complexity, the operation of a monitoring system demands resources and technical expertise. The IMF, for instance, uses aggregated microprudential data to assess the current health of financial institutions. In addition, for their own monitoring purposes, the IMF employs stress tests and scenario analysis to determine the sensitivity of the financial system to macroeconomic shocks, most importantly as part of the IMF's comprehensive financial sector stability assessments (FSSAs) of its member countries, and increasingly in its routine surveillance (IMF, 2001a). Of course, the more sophisticated the system, the more costly it is to monitor and conduct macroprudential analysis or operate early warning systems.

The effectiveness of the monitoring system should be evaluated according to the purpose with which they are designed. For instance, EWS can be evaluated on their record in predicting a crisis. Leading indicators, such as the Conference Board, on the other hand, can be assessed on their ability to pick up turning points in the business cycle. The IMF MPI analysis will be evaluated on how well it can track the vulnerability of financial system as well as how it can effectively disseminate the information to economic agents in the pursuit of better disclosure. Despite the increasing interest in more complex techniques employed in deploying monitoring and early warning systems(see Berg and Pattillo, 1999 for a review), it should be borne in mind that there are at least two aspects in monitoring - the technical identification and interpretation of the indicators. It is thus important not only to define the purposes to which the indicators are to be used as but also the analytical framework within which they are to be interpreted.

The ADB MPIs, on the other hand, are a set of commonly agreed MPIs, among participating countries in RETA 5869, used for monitoring the soundness of the economy, particularly the asset and financial markets. For monitoring the current health or soundness of the asset and financial markets, national authorities or market players can compare the ADB MPIs with certain thresholds or benchmarks. These benchmarks can be generated from historical data or could be provided as standards by international financial institutions. More sophisticated forms of EWS could be set up by individual countries using the ADB MPIs and other statistics which satisfy their specific needs. Although the MPIs are not comparable across countries due to differences in their definition, or in data availability or accounting/compilation standards, it is still instructive to contrast the patterns of the MPIs of crisis affected countries with those of countries that did not suffer from a similar turmoil. The ADB MPIs will aid the aforementioned efforts by providing readily available and updated sets of MPIs across participating member countries. The availability of the MPI could initially form the basis of a peer review process, which could be further refined and formalized as the practice is carried out.

\section{The IMF Framework for MPI Analysis}

Since the advent of the Asian crisis in 1997, IMF has collaborated with national authorities and other international financial institutions in developing MPIs (which the IMF now refers to as financial soundness indicators) and formulating methods in analyzing these indicators of financial soundness. This interest was stimulated, in general, by the rethinking over the effectiveness of mode of IMF surveillance prior to the Asian crisis. Indeed, the fact that the Asian crisis was largely unanticipated has exposed the gaps in surveillance systems on the national, regional, and global levels, 
including within the IMF's bilateral and global surveillance systems. As part of the response, the IMF has worked to create a new Architecture of the Global Financial System, which incorporates more enhanced monitoring and early warning processes, as well as to create strong public disclosure and public information requirements in the design of the New Financial Architecture. In particular, IMF has started to include financial sector surveillance as a core activity, to enhance traditional IMF bilateral surveillance, which during the pre-crisis period, tended to concentrate on macroeconomic policies and balance of payments, and paid lesser attention to issues such as the consequences of financial liberalization, maturity mismatches, build-up of fragility in the financial system, and other capital account issues (UN ESCAP, 2000). These aforementioned issues have been at the core of the loss of confidence in the region during the crisis. Since then the IMF has been working on a series of initiatives to enhance its ability to assess the strength and weaknesses of financial systems and develop the analytical and procedural tools to perform this task. Among these initiatives are the ongoing efforts to develop and use MPIs. This section outlines the IMF framework for MPI analysis as reported in IMF (2001a).

The IMF considers macroprudential analysis as a key element in designing a policy framework on vulnerability analysis. While the focus is the soundness or health of the financial system, it also incorporates general macroeconomic analysis as well as structural analysis to supplement the assessment of the financial system. Among the major components in macroprudential analysis is the specification of MPIs, which are indicators needed in producing reliable assessments of the strengths and vulnerabilities of financial systems, and the encouragement of enhanced disclosure of financial indicators to the markets (IMF, 2001a). Moreover, MPIs are an integral part of the FSSAs, in which they provide inputs to stress testing exercises, and will be increasingly integrated into the regular IMF surveillance of economies whenever major financial sector issues are to be analyzed. One can note that the objectives of macroprudential analysis directly address the two major causes of the crisis-the weakness in the financial sector which was largely undetected and the destabilizing capital flows owing to abrupt shifts of investor sentiments. Thus, timely and appropriate information is a very key element in the process.

\section{IMF MPIs}

The set of MPIs is the statistical building block of macroprudential analysis. It needs be appreciated that in an increasingly complex and integrated global setting, there are myriads of channels where the banking or financial sector can be affected. For example, domestic variables such as credit growth as well as international ones, such as world interest rates, could have an impact on the health of the banking or financial system. Hence, there are potentially numerous indicators that can be collected. In addition, structural issues such as ownership structure and concentration could also affect the robustness of the financial system. Furthermore, there are different levels of analysis that can be conducted and each type calls for different MPIs. For instance, macroprudential analysis focuses on the system wide health and stability whereas microprudential analysis deals with conditions of individual financial institutions (Crockett, 2000).

Given the aforementioned considerations, IMF has adopted a small "core set" of

MPIs, which includes mainly aggregated microeconomic indicators of the health of the financial institutions and indicators of the health of the major clients of financial 
institutions. Furthermore, the coverage of the MPI also extend to indicators of key developments in markets in which financial institutions operate such as real estate markets. Because of the increasing interdependence of the different sectors in an economy and between economies, the set of MPIs should be comprehensive. IMF's initial list of MPIs has three main groupings-aggregated microprudential indicators, macroeconomic indicators and market-based indicators-to reflect the health of financial institutions and the broader extent of systemic soundness of the financial system.

The aggregated microprudential indicators mainly adopt the CAMELS ${ }^{2}$ framework, which is comprised of six groups of indicators reflecting the health of financial institutions: Capital adequacy, Asset quality, Management soundness, Earnings, Liquidity, and Sensitivity to market risk. The macroeconomic indicators are the indicators of soundness in the banking sector and forms an integral part of banking supervision (IMF, 2001a). In addition, the macroeconomic variables reflect the overall economic activity and the vulnerability of the economy to shocks particularly to currency crises and capital flow reversals (Evans et al, 2000). The market-based indicators, on the other hand, incorporate information such as interest rate spreads, not found in the CAMELS, but have a bearing on market or foreign exchange risk of a particular country. Table 1 reports the MPIs under development in the IMF. There has been further development of the indicators as exhibited in Table 1. IMF introduced FSIs, details of which are presented in Tables 2 and 3.

\section{Table 1: Initial List of Macroprudential Indicators}

\begin{tabular}{ll}
\hline Aggregated Microprudential Indicators & Macroeconomic Indicators \\
\hline Capital adequacy & Economic growth \\
Aggregated capital ratios & Aggregate growth rates \\
Frequency distribution of capital ratios & Sectoral slumps \\
& Balance of payments \\
Asset quality & Current account deficit \\
(a) Lending institution & Foreign exchange reserve adequacy \\
Sectoral credit concentration & External debt (including maturity structure) \\
Foreign currency-denominated lending & Terms of trade \\
Nonperforming loans and provisions & Composition and maturity of capital flows \\
Loans to loss-making public sector & Inflation \\
entities & Volatility in inflation interest and exchange \\
Risk profile of assets & Rates \\
Connected lending & \\
Leverage ratios &
\end{tabular}

(b) Borrowing entity

Debt-equity ratios

Corporate profitability

Other indicators of corporate

conditions

Household indebtedness

Management soundness
Volatility in interest and exchange rates

Level of domestic real interest rates

Exchange rate sustainability

Exchange rate guarantees

Lending and asset price booms

Lending booms

Asset price booms

${ }^{2}$ CAMELS is an acronym for six categories of bank performance: capital adequacy, asset quality, management, earnings and liquidity, and sensitivity to market risk. 
Expense ratios

Earnings per employee

Growth in the number of financial

institutions

Earnings/profitability

Return on assets

Return on equity

Income and expense ratios

Structural profitability indicators

Liquidity

institutions

Central bank credit to financial

Deposits in relation to monetary aggregates

Loans-to-deposits ratios

liabilities/

Maturity structure of assets and

Liquid asset ratios

liquidity

Measures of secondary market

money market

Indicators of segmentation of the

Sensitivity to market risk

Foreign exchange risk

Interest rate risk

Equity price risk

Commodity price risk
Contagion effects

Financial market correlation

Trade spillovers

Other factors

Directed lending and investment

Government recourse to the banking

system

Arrears in the economy

Market-based indicators

Market price of financial instruments, incl. Equity

Indicators of excess yields

Credit ratings

Sovereign yield spreads

Source: Evans, O., Leone, A., Gill, M. and Hilbers, P., "Macroprudential Indicators of Financial System Soundness", IMF Occasional Paper, 192, IMF, 2000.

While a broad array of MPIs could give a comprehensive assessment of the financial system, oftentimes the process of collecting and interpreting indicators can be tedious and time consuming. The September 1999 consultative meeting also called for a core set of indicators but was not in favor of using composite indicators for these would be overly simplistic and could be misleading. For this reason, IMF is considering a smaller set of MPIs, which are more useful and convenient for periodic monitoring. The core set comprises 15 indicators for the banking system that are found to be highly useful for monitoring, compilation and dissemination efforts by national authorities (IMF, 2001b). The core set focuses on the banking sector and covers the main categories of bank risk following the CAMELS framework in bank supervision. The IMF core set of FSI is reported in Table 2. 
Number of applications for protection from creditors

Households

Household debt to GDP

Household debt service and principal payments to income

Real estate markets

Real estate prices

Residential real estate loans to total loans

Commercial real estate loans to total loans

$1 /$ Or in other markets that are most relevant to bank liquidity, such as domestic foreign exchange markets.

Source: Sundararajan, V., et. al.,"Financial Soundness Indicators: Analytical Aspects and Country Practices", IMF Occasional Paper No. 212, 2002.

\section{Macroprudential Analysis}

As mentioned earlier, work on analyzing the MPIs is, like the identification of the MPIs, is still in the preliminary stage. Some of the methods being explored include stress testing and scenario playing, Value-at-Risk ( $\mathrm{VaR})$ models, and sectoral balance sheet analysis. However, as echoed in the September 1999 Consultative Meeting of the IMF, analyses of financial sector vulnerability cannot rely on quantitative indicators alone. It is also important to consider qualitative elements $s$ in the assessment of the vulnerability of the financial sector, such as the institutional circumstances and legal framework (Evans et. al., 2000).

Stress testing adds a dynamic element to the analysis of MPIs; that is, it gives indication of the sensitivity or probability distribution of MPI outcomes in response to different macroeconomic shocks and scenarios (IMF, 2001a). There is a range of stress tests depending on the nature of the risk and nature of shocks. One risk model looks at the impact of changes in a macroeconomic variable, such as general economic slowdown, on the changes in indicators of bank exposure to credit risk, such as nonperforming loans (NPLs). The results of stress tests provide information on the elasticity of a given MPI to macroeconomic shocks, and such a measure of sensitivity can itself be used as an indicator of bank vulnerability to risk factors (IMF, 2001a).

Another approach in assessing the vulnerabilities of the financial sector is the $\mathrm{VaR}$ Technique. It is a statistical measure of the maximum risk exposure given the history of recent, large market changes. This approach assesses the vulnerability of the banking system to unforeseen events by estimating the changes in the net worth of a bank if prices of its assets, either on and off balance sheets, were to move in an unfavorable trend. Though appealing, the $\mathrm{VaR}$ has demanding data requirements and the required level of detail of the data make this approach practically suitable only to individual institutions. Thus, $\mathrm{VaR}$ is rarely used in conducting aggregate soundness analysis (IMF, 2001a).

Sectoral balance sheet analysis, on the other hand, is designed to assess vulnerabilities in the financial system from stresses originating elsewhere in the economy. Under this approach, national accounts are broken down into the sectoral components of households, banking institutions, government, etc. By constructing the specific asset and liabilities of each sector and identifying the sensitivity of the components to changes in asset prices, or interest rates, specific points of vulnerability can be picked up. One favorable feature of this framework is that it shows the linkages among sectors that could transmit financial disturbances and could thus help identify areas of buildup of financial stress across sectors and imbalances between asset and liability exposures within each sector. Limitations of data, as well as inability to capture off balance sheet items constrain the adoption of this approach. 


\section{Leading Indicator Approach}

The methodology used for early warning system can be classified into two broad categories, namely (i) the leading indicator approach, and (ii) the discrete-dependentvariable approach (logit and probit models). The former approach extracts early signals from a set of financial soundness indicators (Kaminsky and Reinhart, 1999; Kaminsky, Lizondo and Reinhart, 1998; Goldstein, Kaminsky and Reinhart, 2000). The latter approach, on the other hand, utilizes logit and probit models (Frankel and Rose, 1996; Eichengreen, Rose and Wyplosz, 1995; Berg and Pattillo, 1999; Schnatz (1998, 1999). Bussierie and Frantzscher (2002) discussed the above methodologies in detail. Kaminsky and Reinhart (1996) and Kaminsky, Lizondo and Reinhart (1998) pioneered the leading indicators approach.

The leading indicator approach is traditionally used in predicting turning points of business cycles primarily in industrialized countries. Since the 1997 Asian financial crisis, this approach has been used as early warning systems of currency crisis. In this approach, a set of financial vulnerability indicators is developed and these are transformed into binary signals: When a particular indicator exceeds a critical threshold, a signal is sent. For example, if the ratio of short-term debt to GDP (gross domestic product) (expressed as a percentage) exceeds a given threshold, this given indicator sends a red signal. The selection of an optimal threshold is very important. If a low threshold is chosen, this indicator will send more signals over time. However, this will be at the cost of more false alarms.

Davis (1999) presented various econometric studies used to examine which financial and macroeconomic developments are closely linked to the incidence of systemic banking crises. Among these studies, Hardy and Pazarbasioglu (1998) attempted to identify leading indicators using lagged variables in a multivariate logit models. The analysis was based on a comparable set of indicators belonging to 38 countries for the period 1980-1997. The results of the study showed that the banking crisis is closely linked to the following variables:

1. A sharp decline in GDP growth;

2. Boom-bust cycles of inflation, credit expansion and capital inflows;

3. Increasing real interest rate;

4. An increasing incremental capital output ratio;

5. Decreasing bank deposits;

6. A significant fall in the real exchange rate;

7. Falling imports; and

8. An adverse terms-of-trade shock

The leading indicators differ from countries in one region to those in another regions. Asian distress had been preceded by credit growth and increasing foreign liability, which measured the banking and corporate sector vulnerability.

Kaminsky and Reinhart (1996) studied 20 developed and developing countries for the period 1970-1995 in order to identify macroeconomic leading indicators with systematically different behavior during the period prior to banking and currency crises. The following leading indicators were identified: 
1. A continuous sharp decline in GDP (recession);

2. Falling terms of trade;

3. Crashes in stock market; and

4. An increase in real exchange rates.

\section{Ideal Set of Leading Indicators for Macroprudential Surveillance in Developed Countries}

Davis (1999) attempted to identify a broad ideal set of generic indicators derived from the theory of financial instability and empirical studies of the incidence of financial crises. These indicators are more suitable for developed countries due to unavailability of some of these indicators in developing countries. These indicators can be broadly classified as: (i) flow-of-funds indicators; (ii) financial prices; (ii) monetary data; (iii) Indicators on banks; (iv) external financial indicators; (v) and overall macroeconomic Indicators; and (vi) qualitative indicators. These indicators are presented below:

(i) Flow-of-funds Indicators:

Corporate and Household Sector Gross Indebtedness, relative to Income (Sectoral Income or GDP) or Gross Financial or Total Assets:

1. Corporate and Household Deficits; (Private sector debt could be estimated by the stock of bank lending to the non-bank private sector as a proportion of GDP)

2. Corporate Debt Level;

3. Corporate Debt-Equity Ratio;

4. Household Debt Levels;

5. Measures of Income Gearing (Interest Payment as a proportion of Income)

6. Total Assets of Banks relative to Non Bank Financial Institutions;

7. Growth of Lending to any individual market and to a given sector or region;

Investment Pattern of Institutional Investors

8. The Balance between sources of corporate debt finance in Banking and Bond Markets;

9. Maturity period of Debt (Short term or long term): Domestic and Foreign (cross-border)

Banking Development

10. Growth of Banks' Balance Sheets

11. Overall Capital Adequacy of Banking Sector

(ii) Financial Prices;

1. Overall Equity Prices (Stock Market Index);

2. Equity Prices Index for Financial Institutions; 
3. Commercial and Residential Property Price Index at National and Regional levels (Index for share prices of property related companies as a proxy)

Money Market and Bond Yield Spreads

4. Corporate Bond Spreads (for domestic and international (such as Euro) Bonds) over government bonds;

5. Spreads Bank Loan to Corporate over government bonds (for fixed rate) and over interbank rates (for floating rate);

6. Bank Bond Spreads over Corporate Bonds;

7. 3-month Certificate of Deposits (CD) Spreads

8. 3-month Commercial Papers (CP) Spreads

9. Maturity Period of Debts;

10. Deviation of indices on Equity, Bond and Foreign Exchange Markets from Past Averages

(iii) Monetary Indicators

1. Growth of Broad Money (M2 or M3);

2. Total Credit to the Non-Financial Sector

3. Velocity of Money (Ration of Nominal GDP to Money) and Credit;

4. Real Short-term Interest Rates (Interbank rate less the current rate of Inflation);

5. Real Long-term Interest Rate;

6. Growth of Bank Assets (Total and by Subsector of Banks);

7. Regional and Industrial Sectoral Concentration of Bank loans;

(iv) Indicators on Banking and Financial Structures (Individual Bank Indicators)

Average, Distribution and Time Series of Individual Bank Data on:

1. Capital Adequacy;

2. Margin (net income as a proportion of assets;

3. Liquidity in terms of maturity mismatch and currency mismatch;

4. Non-performing Loans in Proportion to Capitals;

5. Overall Return on Assets or Equity;

6. Profitability;

7. Whole Sale and Retail Funding;

8. The above indicators on Investment Banks and Hedge Fund;

9. Change in Number of Banks;

10. Change in Number of Foreign Banks;

(v) External Financial Indicators

1. Current Account Deficit (as a proportion of GDP);

2. Real Exchange Rate;

3. Real Terms of Trade;

4. Foreign Exchange Reserve;

5. International Foreign Currency Lending- Its Maturity and Sectoral Distribution; 
6. Capital Account Flows in Banking and Portfolio Forms;

7. Short-term Debt in Foreign Currency relative (as a proportion of Total Domestic Debt and of Short-term Assets in Foreign Currency);

8. Direction of Trade Data- Correlation to other Countries at Risk.

(vi) Overall macroeconomic Indicators

1. Real GDP growth at National and Regional Levels and Forecasts;

2. Real Business Fixed Investment and Forecasts (Overall and Real Estate);

3. Inflation and Forecasts.

(vii) Qualitative Indicators

1. Easing of Financial Regulation (Ratio of Broad Money to Narrow Money as a proxy);

2. Recent Financial Innovations;

3. Current Monetary Regime and Its Sustainability;

4. Developments Reducing Entry Barrier to Markets (particularly Technological Change);

5. Coverage of the Safety Net (notably Deposit Insurance or other Implicit or Explicit Guarantee);

6. Potential Correlation Risks between Market Prices

7. Structure and Regulatory Features Limiting Contagion (such as, whether interbank market rate is collateralized, whether payment system is net or gross, regulations of over-the-counter (OTC) positions and perceptions of the credibility of central banks and regulatory authorities);

8. Information Gathered from Operational Activities regarding potential for "herding" and other risks.

\section{Comparison with FSIs Used by Selected Developed and Developing Countries}

IMF and World Bank jointly launched Financial Sector Assessment Program (FSAP) in May 1999. The main objective of this program is to identify financial system strengths and vulnerabilities and to help develop appropriate policy responses. In this regard, IMF undertook Financial System Stability Assessments (FSSAs) in selected countries. In this assessment, all analysis of the health of the banking sector is performed based on the levels and trends in selected Financial Soundness Indicators (FSIs), particularly in the areas of capital adequacy, asset quality, profitability, liquidity and exposure to market risks together with the linkage between these indicators and changes in the macroeconomic environment. According to the IMF study (Sundararajan, et.al, 2002), the range of FSI used in FSSA varied somewhat among countries under the assessment. However, the indicators utilized some adaption of the CAMELS framework.

The most commonly-used FSI in FSSA are presented below, in order of frequency of use:

(i) Profitability indicators such as returns on assets and returns on equity, interest margin ratios, and non-interest income and expenses ratios;

(ii) Asset quality indicators, notably non-performing loan (NPL) ratios and provisions; 
(iii) Capital adequacy ratios, in particular the ratio of regulatory (Basel) capital to risk-weighted assets;

(iv) Sensitivity to market risk indicators, notably open foreign exchange exposures; and

(v) Liquidity ratios.

A comparative analysis between FSIs used in a developed country, Canada and a developing Asian country, India is presented below in Table 4. The analysis shows that Canada uses several liquidity ratios which are not used by India for monitoring purpose. On the other hand, India uses, capital to assets ratio, NPLs net of provisions ratio, non interest expense ratio, and volatility liquidity ration which are not used by Canada.

The identification and use of FSls by a country depends on many factors, such as, (i) unavailability of raw data for compiling some indicators, (ii) supervisory, accounting and statistical standards. Even if common indicators are used by countries for monitoring, these indicators may not be comparable due to difference in prudential, accounting and statistical standards.

Table 4. Comparison of FSIs used Canada and India

\begin{tabular}{lcc}
\hline Financial Soundness Indicators & Canada & India \\
\hline Capital adequacy & & \\
Regulatory capital to risk-weighted assets & Used & Used \\
Tier I capital to risk-weighted assets & Used & Used \\
Capital to assets & Not used & Used \\
Asset quality & & \\
(a) Lending Institutions & & \\
Loans (or credit) by sector & Used & Not Used \\
NPLs to gross loans (or to total assets) & Used & Used \\
Provisions (plus collateral values) to NPLs & Used & Used \\
Provisions to gross loans & Used & Not Used \\
NPLs net of provisions ratios & Not Used & Used \\
(b) Borrowing Institutions & & \\
Total debt to equity & Used & Not Used \\
Earnings & & \\
Return on average assets (ROA) & Used & Used \\
Return on average equity (ROE) & Used & Used \\
Interest margin ratios & Used & Used \\
Non-interest income ratios & Used & Used \\
Non-interest expenses ratios & Not Used & Used \\
Liquidity & & \\
Liquid asset ratios & Used & Not Used \\
Loans (or deposits) to total assets & Used & Not Used \\
Loans to deposits & Used & Not Used \\
Loans and/or deposits by currency & Used & Not Used \\
Volatility ratio & Not Used & Used \\
Sensitivity to market risks & Used & Not Used \\
Net open FX position & & \\
\hline
\end{tabular}




\section{Identification and Evaluation of Core Set of Leading ADB MPIs}

\section{Commonly Agreed ADB MPIs}

The system of ADB MPIs can be classified into three categories, namely, (i) aggregated microprudential indicators of health of individual financial institutions; (ii) macroeconomic indicators concerning the health of financial sectors; and (iii) qualitative business tendency survey indicators. The set is unique as it includes qualitative and leading business tendency survey indicators as key elements. As these will be covered more fully in a later chapter, the MPIs should have a clear theoretical link with the vulnerability and soundness of the financial sector.

The agreed set of indicators is comprised of the core set (commonly agreed) and some additional ones (specific to country needs). Table 5 reports the list of the 67 commonly agreed indicators.

Table 5: ADB Commonly Agreed Macroprudential Indicators

\section{External Debt and Financial Flows}

1. Total $\operatorname{Debt}^{3}$ (\% of GDP)—ratio of total debt on nominal GDP.

a. of which public debt

b. of which private debt

2. Long-Term ${ }^{4}$ Debt (\% of total debt) -ratio of long-term debt to total debt.

3. Short-Term Debt (\% of GDP)—ratio of short-term debt to nominal GDP.

4. Short-Term Debt (\% of total debt) —ratio of short-term debt to total debt.

5. Foreign Direct Investment (\% of GDP)—ratio of foreign direct (expressed as flows) investment to nominal GDP.

6. Portfolio Investment ( $\%$ of GDP)—ratio of portfolio investment (expressed as flows) to nominal GDP

\section{Money and Credit ${ }^{5}$}

7. M1 Growth (\%)-percent difference from previous period. M1 are liabilities of the monetary system consisting of currency and demand deposits.

8. M2 Growth (\%)-percent difference from previous period. M2 equals M1 plus quasimoney.

9. Money Multiplier (Ratio)—ratio of M2 to money base. Money base is the sum of currency in circulation, reserve requirement and excess reserves (with the central bank).

10. M2 (\% of International Reserves) —ratio of M2 to international reserves.

11. M2 (\% of GDP)—ratio of M2 to nominal GDP.

12. M2 to international reserves growth-the growth rate of $M 2$ over international reserves.

3 As defined in the World Bank, Global Development Finance 2000 on CD-ROM and categorization of maturity according to the remaining maturity instead of original maturity.

4 As defined in the World Bank, Global Development Finance 2000 on CD-ROM.

5 Participants at the workshop agreed that these data could be drawn from the monetary statistics that countries supply to the IMF for publication in International Financial Statistics. 
13. Quasi-money (\% of GDP)—ratio of quasi money to nominal GDP.

14. Money Base Growth (\%)-percent difference from previous period.

15. Central Bank Credit to the Banking System-Central Bank's credit to the banking system.

16. Growth of Domestic Credit (\%)-percent difference from previous period. Consists of net claims from central government, claims on official entities and state enterprises, and claims of private enterprises and individuals.

17. Domestic Credit (\% of GDP)—ratio of domestic credit to nominal GDP.

18. Credit to Public Sector (\% of GDP)—ratio of credit to public sector to nominal GDP.

19. Credit to Private Sector (\% of GDP)—ratio of credit to private sector to nominal GDP.

20. Capital Adequacy Ratio (\%) - ratio of total capital to risk weighted assets (threshold value is $8 \%$ meaning that the ratio should not be less than this value). Ratio of Tier 1 + Tier 2 capital to risk weighted assets. Tier 1 capital includes issued and paid-up share capital, non-cumulative preferred stock and disclosed reserves from post-tax retained earnings. Tier 2 capital can include a range of other entities. These are undisclosed reserves that passed through profit and loss account, conservatively valued revaluation reserves, revaluation of equities held at historical cost (at a discount), some hybrid instruments, general loan loss reserves (up to $1.25 \%$ of risk weighted assets) and subordinated term debt.

21. Liquidity Ratio (\%)-The ratio of commercial banks' liquid assets to total assets: a) domestic liquid asset ratio and b) foreign liquid asset ratio.

\section{Banking}

22. Bank Capital (\% of Total Assets)—ratio capital equity including reserves, profits and loss to total assets.

23. Total Assets (\% of GDP) — ratio of total assets (as in Monetary Survey without interbank positions) to nominal GDP.

24. Growth of Total Assets (\%)—percent growth from previous period.

25. Share of 3 Largest Banks (\% of total asset)

26. Net Operating Profits (as \% of period-average Assets)

27. Loan-Loss Provisions (\% of Non-Performing Loan)-ratio of loan loss provision to non-performing loans

28. Non-Performing Loans (\% of total loan)—ratio of non-performing loans

29. Loans to the Key Economic Sector \& (\% of Total Loans)

30. Real Estate Loans (\% of Total Loans) - ratio of real estate loans to total loans.

31. Total Loans (\% of Total Deposits) —ratio of total loans to total deposits (i.e., demand deposits, savings deposits and time deposits)

32. International liability from Banks with Maturities, Total (Mn US\$) - total international liability from commercial banks.

a. Short-term borrowing

b. Long-term borrowing-more than one year

33. International liability with Maturities, one year and less (Mn US\$) — total international liability from commercial banks.

\section{Interest Rates (mean rate)}

(In case of monthly data, average of daily rates; in case of quarterly data, monthly averages are to be applied)

34. Central Bank Lending Rate (a.o.p.) - average of period; rate at which the monetary authorities lend or discount eligible paper for deposit money banks. 
35. Commercial Bank Lending Rate (a.o.p.)/Prime Rate-average of period; ratio of commercial bank lending rate to prime rate. Prime rate refers to the short and medium term financing needs of the private sector.

36. Money Market Rate/Interbank Rate (a.o.p.) —average of period; rate at which shortterm borrowings are effected between financial institutions.

37. Short-term (3 mos.) Time Deposit Rates-interest rates of savings account held in a financial institution for 3 months or with the understanding that the depositor can withdraw only by giving a notice.

38. Long-term (12 mos.) Time Deposit Rates-interest rates of savings account held in a financial institution for 12 months or with the understanding that the depositor can withdraw only by giving a notice.

39. US\$ (international market)/Domestic Real Deposit Interest Rate-unweighted averages of offered rates quoted by at least 5 dealers early in the day for 3-month certificates of deposit in the secondary market.

40. Bond/Treasury Bill Yield (short term)-yield to maturity of government bonds (shortterm)

41. Bond/Treasury Bill Yield (long term)-yield to maturity of government bonds (longterm)

\section{Stock Markets and Bonds}

42. Foreign Share in Trading (\% of Total Volume of Trading)-proportion of foreign share in trading to total volume of trading.

43. Share of 10 Top Stocks in Trading (\% of Total Volume of Trading)_proportion of top 10 stocks in trading to total volume of trading.

44. Composite Stock Price Index (Capital City; in national currency unit)-equity price index of national capital city and expressed in national currency unit.

45. Composite Stock Price Index Growth (Capital City)-percent difference from previous period of equity price index; end of period and based on national currency unit.

46. Composite Stock Price Index (Capital City; in US\$)-equity price index of national capital city and expressed in US\$.

47. Market Capitalization (\% of GDP)—ratio of market capitalization to nominal GDP. Market Capitalization refers to the total market value of stocks or shares.

48. Stock Price Earning Ratio

\section{Trade Exchange and International Reserves}

49. Export Growth (\%)—export growth (FOB) percent difference from previous period.

50. Import Growth (\%)-import growth (CIF) percent difference from previous period.

51. Trade Balance (Mn US\$)-difference between exports (FOB) and imports (CIF)

52. Current account deficit/surplus (Mn US\$)

53. Exchange Rate (average of period)—national currency unit to the US\$

54. Exchange Rate (end of period) - national currency unit to the US\$

55. Real Effective Exchange Rate-ratio of an index of the period average exchange rate of a currency to a weighted geometric average of exchange rate for the currencies of selected countries adjusted for relative movements in national prices of the home country and the selected countries. Refers to the definition used in the IMF, IFS series.

56. International Reserves (Mn US\$) -international reserves include total reserves minus gold plus gold national valuation. 
57. Growth of International Reserves (\%)-percent difference from previous period.

58. International Reserves (\% of imports) — ratio of international reserves to total imports.

\section{Business Survey Data (Manufacturing, Construction, Trade, Services)}

59. Assessment of Current Business Situation

60. Expectations on Business Situation in Next Months/Quarters

61. Limits to Business (Present Situation)

62. Stocks of Finished Products (Present Situation)

63. Assessment of Order Books

64. Selling Prices (Future Tendency)

65. Employment (Future Tendency)

66. Financial Situation (Present Situation)

67. Access to Credit (Present Situation)

\section{A. Additional Indicators}

\section{External Debt and Financial Flows:}

1. Short-Term Debt (\% of foreign reserves)

2. Use of IMF credit (\% of GDP)—ratio of IMF credit to nominal GDP

\section{Money and Credit (these data can be drawn from IFS)}

3. Growth of Currency in circulation (\%)

4. M3 Growth-percent difference from previous period. M3 equals M2 plus liabilities of other financial institutions.

\section{Banking}

5. Non-Performing Loans (\% of Average Assets): simple average of assets over the period

6. Loans to Commercial Real Estate Sector (\% total loans)

7. Loans to Residential Real Estate (\% total loans)

8. International liability from bank with Maturities, over 1 year and up to 2 years (Mn US\$) - total international liability from commercial banks.

9. International liability from bank with Maturities, over 2 years (Mn US\$) -total international liability from commercial banks.

10. International liability from bank with Maturities, unallocated ( $\mathrm{Mn}$ US\$)-total international liability from commercial banks.

11. Gini coefficient of market shares of banks in terms of assets.

\section{Interest Rates}

12. Real Deposit Rate (3 mos.) (a.o.p.) - average of period; defined as the difference between deposit and inflation rate.

13. Real Lending Rate (3 mos.) (a.o.p.)-average of period; defined as the difference between commercial bank lending and inflation rate.

14. Real Lending Rate-Real Deposit Rate (each 3 mos.)-difference between commercial bank lending rate and deposit rate. 
15. Real Lending Rate/Real Deposit Rate (each 3 mos.) —ratio of real lending rate to real deposit rate.

\section{Stock Markets and Bonds}

16. Gini Coefficient of Market Share of Stocks in Trading - measure of concentration of market capitalization (inequality of market share among the stocks traded during the day). It is the ratio of the actual concentration of total value stocks among traded companies to the maximum concentration.

where:

$$
\begin{aligned}
& \text { GiniCoefficient }=\frac{N+1}{N-1}-\frac{2}{N(N-1) A}\left(\sum_{i=1}^{N} P_{i} a_{i}\right) \\
& P_{i}=\quad \begin{array}{l}
\text { is the rank of each company in the stock market counting } \\
\text { from the top in terms of stock assets or market capitalization }
\end{array} \\
& a_{i}=\quad \begin{array}{l}
\text { stock asset of ith company } \\
A=\quad \text { total asset or market capitalization of all securities } \\
N=\quad \text { total number of companies listed }
\end{array}
\end{aligned}
$$

17. Turnover in stocks (as \% of Market Capitalization)

18. Turnover in Bonds (as \% Market Capitalization)

a. Volume of Government Bonds Traded

b. Volume of Corporate Bonds Traded

19. Turnover in Mutual Funds (as \% Market Capitalization)

20. Foreign investment in stock by sector

\section{Business Survey Data (Manufacturing, Construction, Trade, Services)}

21. Production/Turnover (Present tendency)

22. Production/Turnover (Expected Tendency)

23. Capacity Utilization (Present Situation)

24. Credit Demand by Sector (only for Survey in Financial Sector)

\section{Supervisory Surveys}

25. Lending and Credit Standards of Financial Institutions

\section{Additional Topics from IMF Indicator List}

(For definition No. 20-38 see IMF Questionnaire)

26. Number of applications for protection from creditors

27. Corporate debt-equity ratio

28. Ratio of Corporate Post-Tax Profits to Equity

29. Ratio of Corporate Debt Service Costs to Gross Corporate Income

30. Corporate Net Foreign Currency Exposure

31. Ratio of Household Total Debt to GDP

32. Ratio of Household Mortgage Debt to GDP 
33. Household Debt Owed to Depository Corporations

34. Ratio of Household Debt Service Costs to Household Gross Income

35. Rate of Growth in Number of New Depository Corporations

36. Proportion of Institutions Having License Withdrawn

37. Spreads Between Reference Lending Rates and Reference Borrowing Rates

38. Spreads Between Depository Corporations' Securities and the Rate of Comparable Treasury Securities

39. Spreads Between Depository Corporations' Subordinated Debt Securities and the Rate for Comparable Treasury Securities

40. Distribution of 3-Month Local Currency Interbank Rates for Different Depository Corporations

41. Average Interbank Bid-Ask Spread for 3-Month Local Currency Deposits

42. Average Maturity of Assets

\section{Others}

\section{Real Estate Price Index and Its Growth Rate}

\section{identification of Core Set of Leading Indicators}

Bhattacharyay and Nerb (2002) identified a core set of leading indicators that could give early warning signals of vulnerability of financial markets, based on trend analysis of the series of 67 commonly agreed MPIs compiled by selected Asian countries under the above ADB project. Those indicators which exhibited conspicuous behavior prior to 1997 Asian financial crisis are selected.

One of the main objectives of this exercise is to identify indicators which appear to be particularly promising for financial and economic monitoring and which therefore should be included in a core list of harmonized indicators at ADB. Although a broad and exhaustive set of indicators could potentially give a more complete assessment of the soundness of financial systems, they can be costly to compile and unwieldy to maintain for the purpose of periodic monitoring. Hence, the workshops recommended that a separate core set of MPIs of manageable size be kept and updated regularly. Apart from this core set of indicators, there will be a number or series of special importance in some countries but not in all.

As indicated earlier, one criterion for inclusion in the core set of MPIs is early warning capacity. Hence, the MPI should be a leading indicator or at the very least, a coincident one. For a short-term monitoring system, however, only indicators which are available at least on a quarterly basis (even better on a monthly one) can be useful. However, this requirement is not always fulfilled by many Asia-Pacific countries.

As the data series provided by the countries participating in RETA 5869 are not very long (available only from 1995 onwards or even later) and are not always complete over the whole time span, it may not be appropriate at this stage to apply formal statistical methods like regression or factor analysis to identify the best candidates for a harmonized set of core MPIs but to use in this first round graphical inspection of the series. In a later stage, more formal statistical methods should be applied to identify the exact informational content of those series and to use multivariate analysis to estimate the joint impact of different subsets of indicators for explaining and forecasting banking and currency crises. 
In choosing the core set of MPIs, the study applied trend analysis on the set of indicators earlier identified to see how they were behaving prior to the 1997 Asian financial crisis. According to this pragmatic approach, the following series have been selected for the core set of ADB MPIs. In cases where a clear lead could not be detected, this is labeled with coincident/leading. It appears at this stage that it is not possible to give a range of the lead in months or weeks. For this purpose, observations over a longer time span and the construction of a synthetic curve acting as reference series to measure the lead against would be necessary. Table 6 presents the core set of leading MPIs which are selected on the basis of trend analysis of commonly agreed indicators.

Table 6: The Core Set of Leading MPIs

\begin{tabular}{|c|c|c|}
\hline Type of Indicator & Title & racteristics \\
\hline \multicolumn{3}{|l|}{ Money and Credit } \\
\hline $\begin{array}{l}7 . \\
8 . \\
4 . \text { (additional) } \\
15 . \\
16 . \\
17 . \\
19 .\end{array}$ & $\begin{array}{l}\text { M1 Growth (in \%) } \\
\text { M2 Growth (in \%) } \\
\text { M3 Growth (in \%) } \\
\text { Central Bank Credit To Banking System } \\
\text { Domestic Credit Growth (in \%) } \\
\text { Domestic Credit Growth (in \% of GDP) } \\
\text { Credit to Private Sector (in \% of GDP) }\end{array}$ & $\begin{array}{l}\text { leading } \\
\text { leading } \\
\text { leading } \\
\text { coincident/leading } \\
\text { coincident/leading } \\
\text { coincident/leading } \\
\text { coincident/leading }\end{array}$ \\
\hline \multicolumn{3}{|l|}{ Banking } \\
\hline $\begin{array}{l}26 . \\
31 . \\
33 . \\
6 . \text { (additional) }\end{array}$ & $\begin{array}{l}\text { Net Bank Profits (in \% of Total Assets) } \\
\text { Total Bank Loans (in \% of Total Deposits) } \\
\text { International Borrowings with Maturities } \\
\quad \text { one year and less (Mn. US\$) } \\
\text { Real Estate Loans }\end{array}$ & $\begin{array}{l}\text { leading } \\
\text { leading } \\
\text { leading } \\
\text { leading }\end{array}$ \\
\hline \multicolumn{3}{|l|}{ Interest Rates } \\
\hline 36. & Money Market Rate/Interbank Rate & leading \\
\hline \multicolumn{3}{|c|}{ Stock Markets and Bonds } \\
\hline $\begin{array}{l}44 . \\
47 . \\
48 .\end{array}$ & $\begin{array}{l}\text { Composite Stock Price Index } \\
\text { Market Capitalization (in \% of GDP) } \\
\text { Stock Price Earning Ratio }\end{array}$ & $\begin{array}{l}\text { leading } \\
\text { leading } \\
\text { leading }\end{array}$ \\
\hline \multicolumn{3}{|c|}{ Trade Exchange and International Reserves } \\
\hline $\begin{array}{l}55 . \\
56 .\end{array}$ & $\begin{array}{l}\text { Real Effective Exchange Rate } \\
\text { International Reserves }\end{array}$ & $\begin{array}{l}\text { coincident/leading } \\
\text { leading }\end{array}$ \\
\hline
\end{tabular}


Business Survey Results

59.

60.

62.

65.

66.
Current Business Situation

Expected Business Situation

(next 6 months)

Stocks of Finished Products

Employment (Present Situation)

Financial Situation (Present Situation) coincident/leading

coincident/leading

coincident/leading

coincident/leading

coincident/leading

According to business cycle and economic indicator research, reliable indicators (both coincident and leading) should not only have a sound statistical basis (e.g. broad coverage, representative, no missing data), short delay in publication, limited ex-post revisions, a good track record in the reference period, and importantly, a solid theoretical foundation. Otherwise, there exists the problem of measurement without theory ("fishing in the data").

\section{Evaluation: Illustrative Analysis of Interpreting Leading Indicators for Financial Vulnerability}

Any monitoring process, like the MPI analysis, has two main parts-one is objective and the other, subjective. The objective element includes identification and collection of the indicators while the subjective element comprises their interpretation. Economic theory, along with empirical evidence of indicators anticipating crises drives the process of identification of the indicators. The interpretation or analysis, on the other hand, is conducted based on a framework derived from the literature on economic crises and financial markets. In addition, quantitative analysis can be complemented by qualitative assessments or value judgments. The task of developing MPIs and interpreting them present considerable challenges especially to policy makers. For policy makers in developing countries, this challenge is all the more daunting because of the relatively novel application of MPIs in developing country settings, more generally.

There are numerous ways of interpreting MPIs and as yet, there is no consensus as to what constitutes an "optimal" system. The analysis or interpretation of MPIs could be undertaken using methods of considerable complexity such as the VaR models. Bernhill, Pappanagiotou, and Schumaker (2000) used VaR framework to measure banks' integrated market and credit risks. Alternatively, it is possible to use simple rules of thumb (such as "safe" or prudent current account deficits or "reserves equivalent to months of import cover") as benchmarks for assessing the vulnerability of economic and financial systems. The choice of the analytical method will depend on the particular objective of the process and the cost involved. Obviously, systems which try to track the probability of a crisis tend to be more complex (and costly) than those that merely signal indications of possible vulnerabilities. At present, no universal model exist which can produce accurate probability of a crisis for any country.

Benchmark and norms play an important role in guiding interpretations of leading MPIs. A benchmark can be constructed in various ways. Commonly used methods include: (i) historical average of the MPIs (ii) use benchmark of other countries at similar levels of financial and economic development (iii) cross country comparisons (iv) benchmark constructed from econometric or statistical studies, and (iv) prudential limit 
stipulated by financial institutions or markets supervisory authorities at the aggregated levels.

A natural starting point for interpreting MPIs is to construct simple benchmarks, which signify the critical levels of vulnerabilities in the financial and economic systems. In principle, once MPIs cross the benchmark, a signal is emitted that alerts policymakers to look more closely or to investigate possible stresses in the financial or economic systems. Again, the choice or level of benchmark is determined by the objective of the model used as well as the availability of good quality data. For example, early warning systems that use composite indicators (Kaminsky, 1998, for example) tend to use more sophisticated methods of computing for the benchmarks. On the other hand, simpler models such as Salvatore (1999) employ conventional standards or "rules of thumb" as benchmarks.

Determining the appropriate benchmark or critical factor is very much a matter of policy judgment considering that policy makers have to weigh the tradeoffs involved. To illustrate, a lax benchmark permits stresses to develop to unsustainable levels before policy makers are made aware of the need to implement crisis-preventive measures. Too tight benchmarks, on the other hand, may lead the monitoring system to emit too many false signals that do not really warrant attention and perhaps erode faith in the usefulness of warning indicators. In the final analysis, the choice of the benchmark will depend on the degree of accuracy that the users expect from the monitoring system.

An attempt will be made in this section to illustrate the use of simple benchmarks in interpreting the MPIs for selected countries that participated in ADB's project: RETA 5869. The objective of the exercise is to use the MPI system in detecting indications (not probabilities) of vulnerabilities in the economic and financial systems. Hence, The ADB MPI analysis does not make claims on crisis prediction. The objective is to give a "first pass" alert signal to the respective authorities when MPIs deviate from what is considered "normal" levels. Neither is the ADB MPI analysis geared to generate composite indicators or a single "vulnerability" or "crisis" index. Because the ADB MPI analysis is aimed to give a general indication rather than a strict probability of crisis, as a first approximation the benchmarks employed are determined as simple averages of the MPIs available during the pre-crisis period. On occasion, this procedure generates "benchmark" levels that appear extreme or "imprudent". These cases are noted in the text, and some a priori more prudent levels are suggested. Besides, the analysis should not be determined solely by the application of MPI, but has to be complemented by qualitative assessments.

The most significant limitation in interpreting the ADB MPIs is the short data span-which covers only the period 1994 to 1999, and includes the structurally different pre-crisis, crisis, and post-crisis periods. The second limitation pertains to the frequency of the MPI, as only annual data are readily available from some of the participating RETA countries. Hence, the benchmarks constructed are rather simple and merely illustrative.

In identifying the benchmarks of the ADB MPIs, recourse has been made on known information on episodes of crisis. In this illustrative case, the five-year range is divided into three segments: (i) the pre-crisis period (1994-1995), (ii) the crisis period (1996-1997), and (iii) the post-crisis period (1998-1999). Alternatively, a ceiling can be calculated as the average of the values of the MPIs over the three periods. As the data 
series provided by the countries participating in RETA 5869 are not very long and are not always complete over the whole time span, it is not appropriate at this stage to apply formal statistical methods like regression or factor analysis to identify the best candidates for a harmonized set of core MPIs but to use in this first round graphical inspection of the series.

The Bhattacharyay and Nerb (2002) identified 22 MPIs that appear to be suitable leading indicators. The analysis of this set of 22 core leading indicators is presented in the following sections. Due to the lack of required data, the analysis on Viet Nam is not included.

\section{Illustrative Interpretation}

\section{Money and Credit}

It is observed that a rapid growth of money and credit usually precede financial and currency crises. One view is that too rapid a growth in money and credit may lead to uncontrollable inflation, loss of international reserves, and ultimately, the demise of the currency regime (Krugman, 1979). Another view is that excessive money and credit growth, in light of an underdeveloped banking system, may easily lead to speculative and unproductive investments-such as real estate ventures in Thailand-that could eventually strain the financial sector of an economy (Moreno, 1998). The next section attempts to illustrate the behavior of the MPIs reflecting money and growth with the crisis episode. The objective is to analyze the movement of the monetary and credit MPIs prior to the crisis in order to get a rough indication of whether the specified indicators are indeed leading.

\section{M1 Growth}

Figure 1 plots M1 annual growth rates across five member countries, namely, Fiji, Indonesia, Philippines, Taipei, China and Thailand. A visual inspection of the graph indicates that the behavior of M1 growth prior to crisis appear to conform to theory for Thailand and the Philippines. Prior to the outbreak of the crisis, there is some indication that M1 growth rates in both the Philippines and Thailand were relatively high. However, these growth rates were followed by the sudden increase in M1 growth after the crisis. Of course, this behavior may simply be due to the up-tick of consumer spending following the low consumption levels during the crisis years, or a scale effect. The behavior of M1 growth rate for Indonesia, however, does not seem to fit with the patterns observed with the Philippines and Thailand.

M1 surged on two occasions, during the pre-crisis period and during the postcrisis period. A correction was made during the crisis period. Hence, based on the patterns of M1 growth for the participating countries, it is not easy to determine the benchmarks of critical levels. 
Table 7: M1 Growth Across Countries (year-on-year)

\begin{tabular}{lrrrrrrr}
\hline \multicolumn{1}{c}{ Country } & $\mathbf{1 9 9 4}$ & $\mathbf{1 9 9 5}$ & $\mathbf{1 9 9 6}$ & $\mathbf{1 9 9 7}$ & $\mathbf{1 9 9 8}$ & $\mathbf{1 9 9 9}$ & $\mathbf{2 0 0 0}$ \\
\hline Fiji & -4.78 & 12.25 & 10.61 & -2.41 & 10.92 & 40.60 & -14.50 \\
Indonesia & & & 21.66 & 22.24 & 29.17 & 23.16 & 30.13 \\
Philippines & 13.50 & 21.70 & 20.02 & 16.38 & 8.98 & 40.00 & \\
Taipei, China & & 0.74 & 8.24 & 11.37 & 2.87 & 14.08 & \\
Thailand & & 12.10 & 9.10 & 1.20 & 3.00 & 30.10 & -8.60 \\
\hline
\end{tabular}

Sources: Country Metadata and ADB Website

\section{M2 Growth}

The analysis for M2 follows closely that of M1. For the Philippines and Thailand, there is an indication of relatively high M2 growth rate prior to the crisis of 1997 albeit not as conspicuous as theoretically expected. Indonesia's M2 growth rate showed a marked increase in 1998, seemingly at odds with the theory that money supply usually peaks prior to a crisis. Hence, M2 may not be a suitable leading indicator for financial vulnerability in Indonesia as it is for the Philippines and Thailand.

It may be possible to adopt a crude benchmark for M2 growth for both the Philippines and Thailand by using the average growth rates of M2 in the period prior to the crisis. For the Philippines and Thailand, the ceilings are 20.54 percent and 14.80 percent (Table 8), respectively, which seems imprudently high. If M2 growth rates reach these levels, there is a need to look closer into the extent of vulnerability of the real and the financial systems.

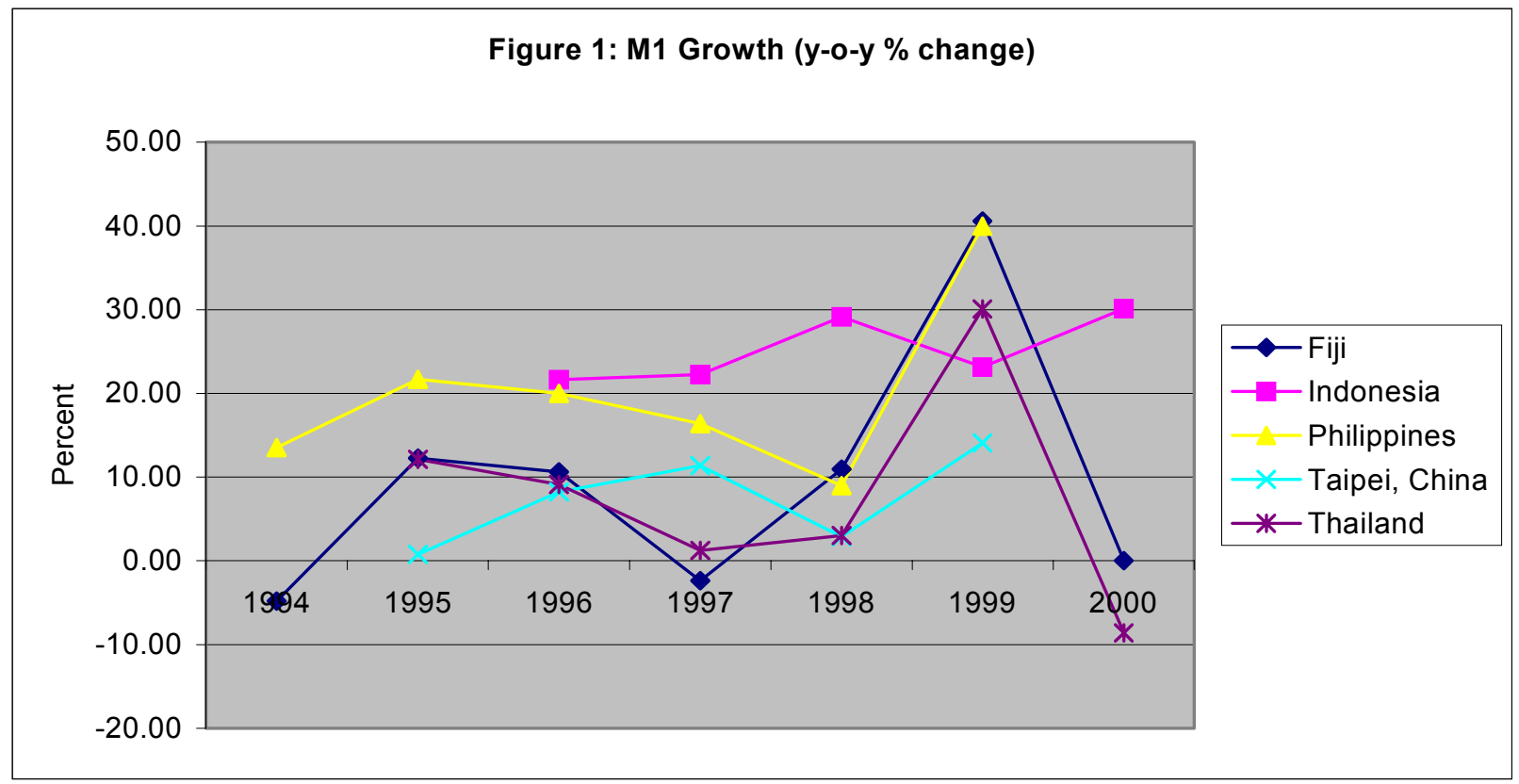


Figure 2: M2 Growth (y-o-y \% change)

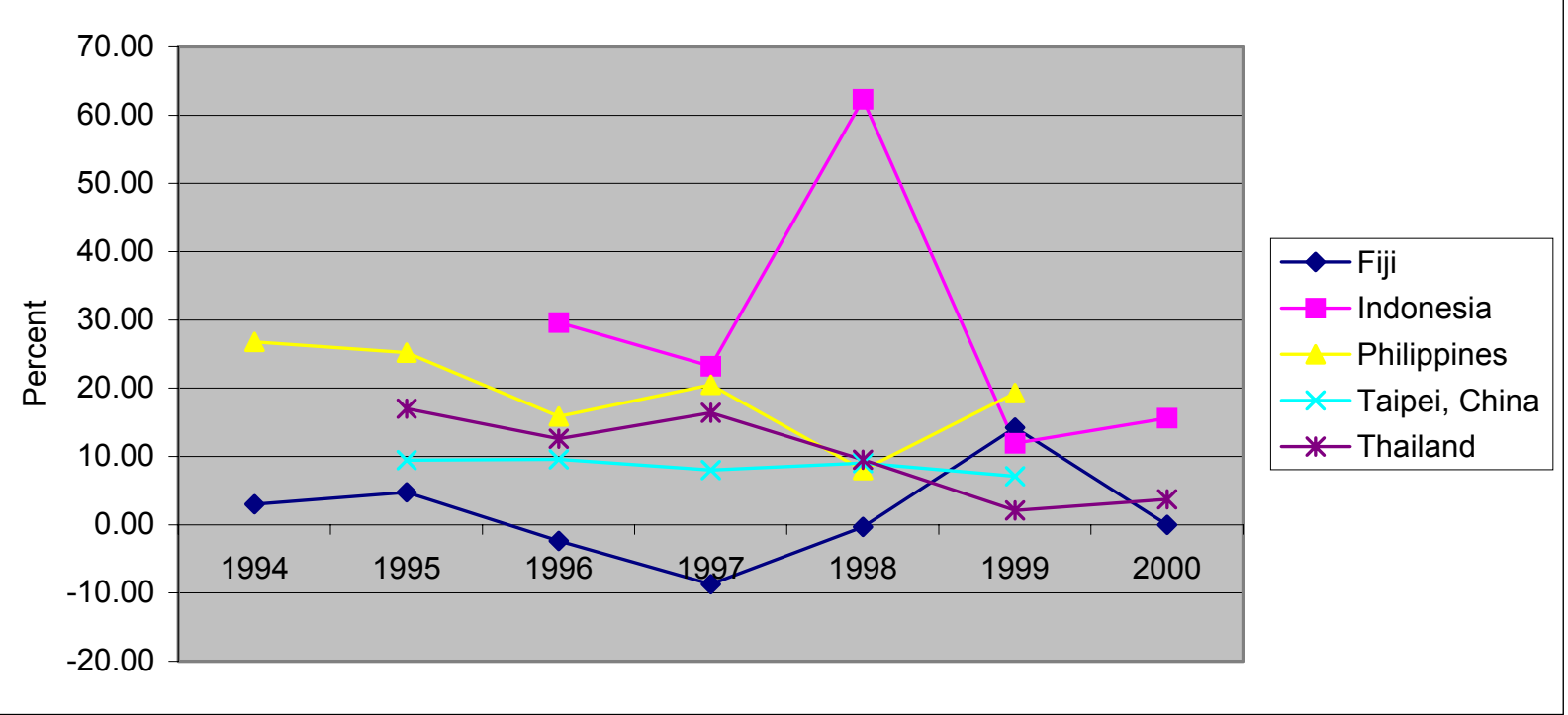

Table 8: M2 Growth Across Countries (year-on-year)

\begin{tabular}{lrrrrrrr}
\hline \multicolumn{1}{c}{ Country } & $\mathbf{1 9 9 4}$ & $\mathbf{1 9 9 5}$ & $\mathbf{1 9 9 6}$ & $\mathbf{1 9 9 7}$ & $\mathbf{1 9 9 8}$ & $\mathbf{1 9 9 9}$ & $\mathbf{2 0 0 0}$ \\
\hline Fiji & 2.97 & 4.73 & -2.36 & -8.72 & -0.35 & 14.20 & -2.09 \\
Indonesia & & & 29.64 & 23.22 & 62.35 & 11.92 & 15.60 \\
Philippines & 26.76 & 25.24 & 15.83 & 20.48 & 8.02 & 19.28 & \\
Taipei, China & & 9.45 & 9.55 & 8.03 & 9.04 & 7.08 & \\
Thailand & & 17.00 & 12.60 & 16.40 & 9.50 & 2.10 & 3.70 \\
\hline
\end{tabular}

Sources: Country Metadata and ADB Website

\section{M3 Growth}

Consistent with the above findings, the behavior of M3 in the Philippines and Thailand generally conforms to expected behavior (see Figure 3). M3 growth rates in both economies were conspicuously high prior to the episode of 1997-1998. Again, following earlier procedures, the illustrative country-specific pre-crisis growth rates for M3 growth in the Philippines and Thailand are 20.54 percent and 15.90 percent (see Table 9), respectively. 
Figure 3: M3 Growth (y-o-y \% change)

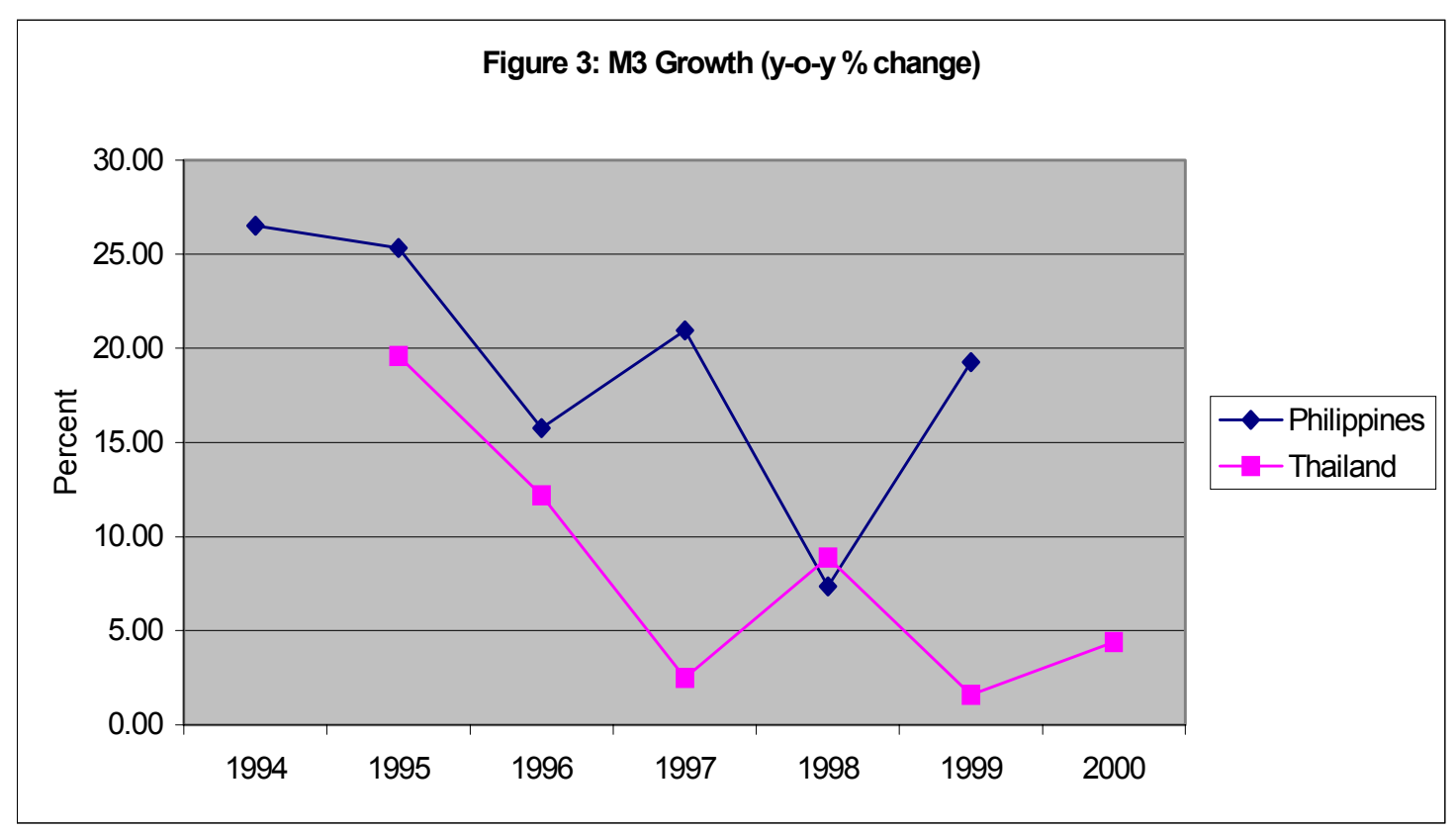

Table 9: M3 Growth (year-on-year percent growth)

\begin{tabular}{|c|c|c|c|c|c|c|c|c|}
\hline Country & 1994 & 1995 & 1996 & 1997 & 1998 & 1999 & 2000 & $\begin{array}{c}\text { Average for } \\
1994-1995\end{array}$ \\
\hline Philippines & 26.50 & 25.31 & 15.76 & 20.95 & 7.37 & 19.27 & & 20.54 \\
\hline \multicolumn{9}{|l|}{ Taipei, China } \\
\hline Thailand & & 19.60 & 12.20 & 2.50 & 8.90 & 1.60 & 4.40 & 15.90 \\
\hline
\end{tabular}

\section{Central Bank Credit to Banking System}

A large increase in central bank credit to banks and other Fls often reflects an attempt by the authorities to address severe illiquidity in the banking system. If the condition of illiquidity ceases to be isolated to a particular bank but has become systemic, it is possible for the illiquidity condition to deteriorate into a solvency issue. Thus, this indicator should, as empirical evidence has proved, be viewed as a short leading or coincident indicator. The following figures are the graphs of central bank credit to banking system across Fiji, Indonesia, Philippines, Taipei, China and Thailand. For the affected economies, the variable is in accord with theory. However, based on the given data, it is not possible to establish a common benchmark since this indicator is expressed in different units for each economy. Alternative specifications may include central bank credit to banking sector as a percentage of GDP to reflect the relative magnitude or scale of credit. Nevertheless, an analysis of the behavior of central bank credit across time could be useful. 
Assuming that the pre-crisis period average of this variable is the norm, it is reasonable to use this as a benchmark. If central bank credit to the banking system is a short leading/coincident indicator in which the behavior of this variable is expected to be abnormal only within a short period prior that represents the run up to the period of extreme vulnerability.
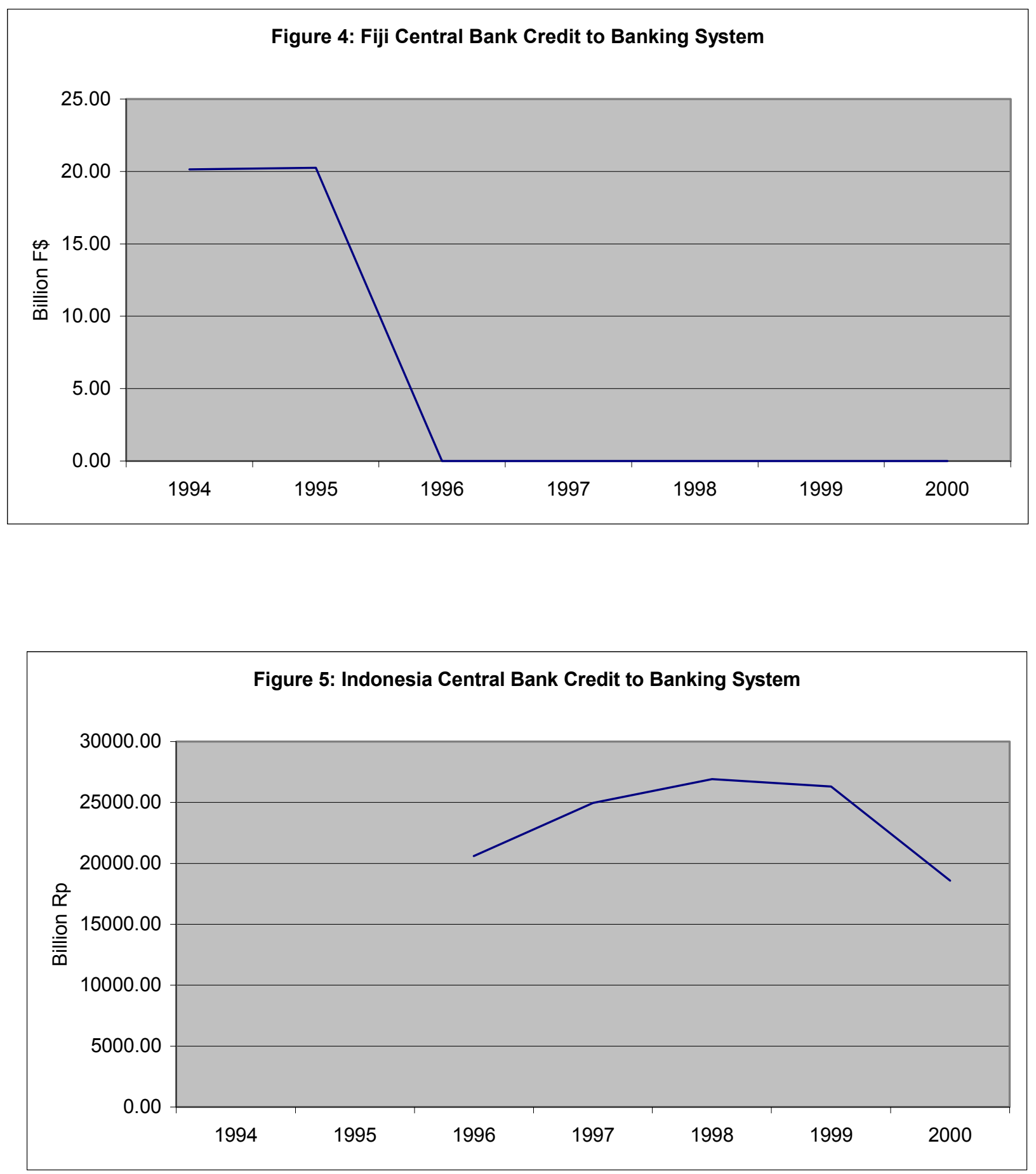

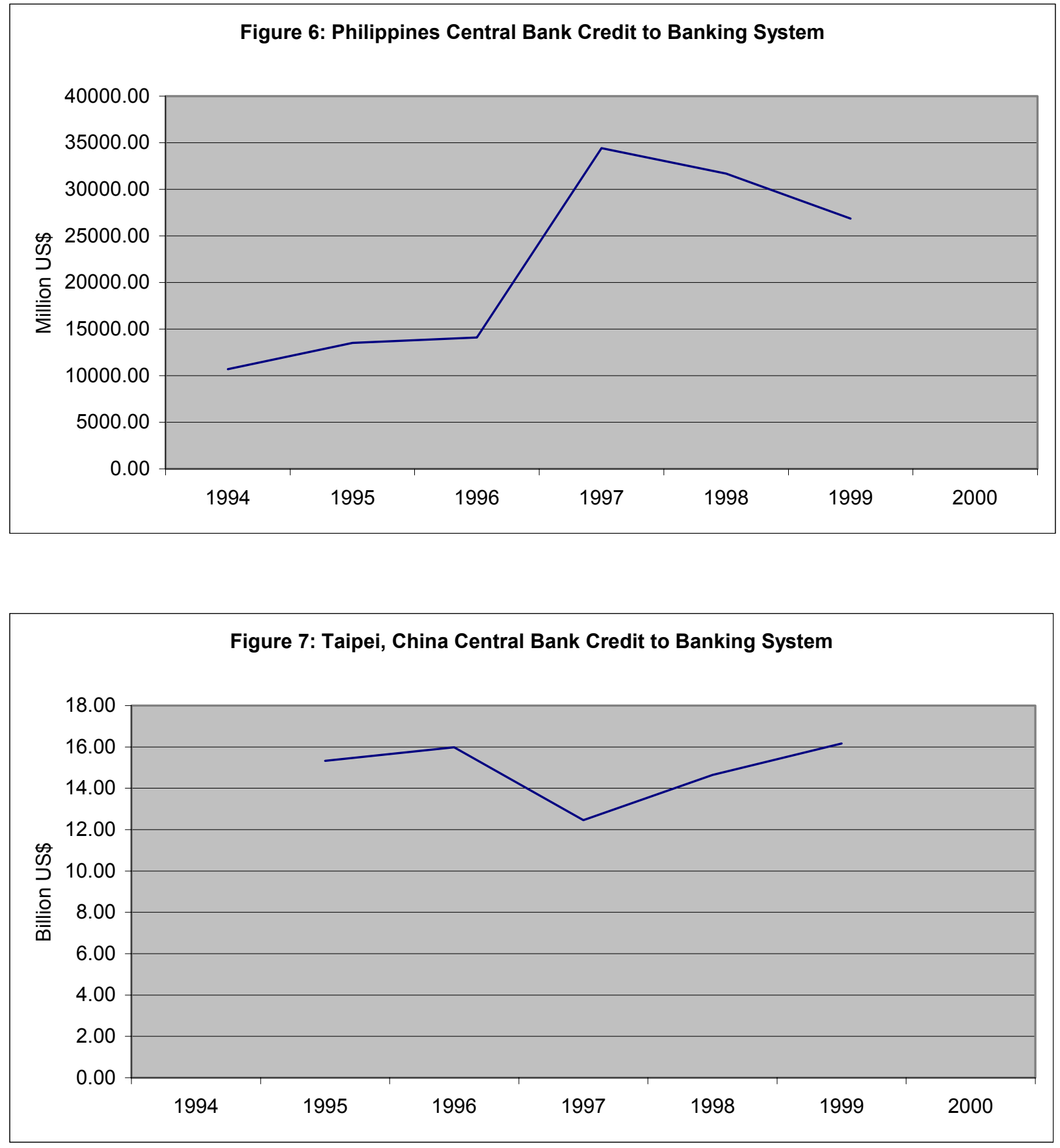
Table 10: M2 Growth Across Countries (year-on-year)

\begin{tabular}{|c|c|c|c|c|c|c|c|}
\hline Country & 1994 & 1995 & 1996 & 1997 & 1998 & 1999 & 2000 \\
\hline $\begin{array}{l}\text { Fiji (B Fiji \$) } \\
\text { Indonesia }\end{array}$ & 20.15 & 20.25 & 0.00 & 0.00 & 0.00 & 0.00 & 0.00 \\
\hline $\begin{array}{l}\text { B Rupiah) } \\
\text { Philippines }\end{array}$ & & & 20600.00 & 24957.00 & 26912.00 & 26308.00 & 18576.00 \\
\hline $\begin{array}{l}\text { (M US\$) } \\
\text { Taipei, China }\end{array}$ & 10691.10 & 13511.00 & 14104.30 & 34430.40 & 31691.80 & 26859.00 & \\
\hline $\begin{array}{l}\text { B US\$) } \\
\text { Thailand }\end{array}$ & & 15.33 & 15.98 & 12.46 & 14.65 & 16.16 & \\
\hline (B Baht) & & 31.50 & 26.50 & 276.30 & 139.60 & 78.90 & 122.30 \\
\hline
\end{tabular}

Sources: Country Metadata and ADB Website

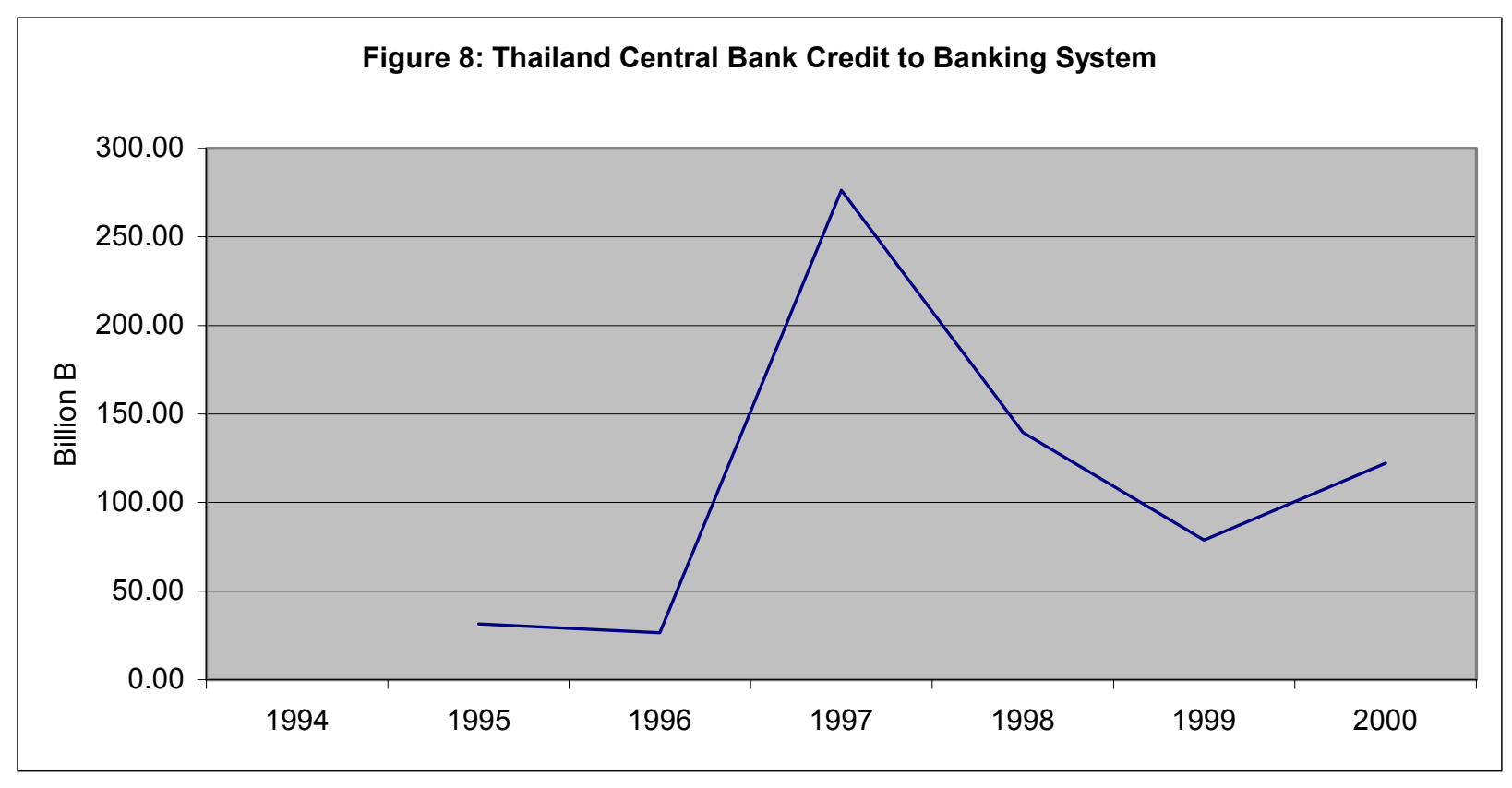

\section{Domestic Credit Growth}

It is observed that crises are often preceded by high domestic credit growth. This behavior is graphically evident for Indonesia, the Philippines and Thailand (see Figure 9). For this reason, domestic credit growth may be a useful indicator in picking up points of increasing vulnerability. Again, as with the monetary aggregates, the pre-crisis period average can serve as a ceiling or threshold. Following this procedure yields the illustrative thresholds for Indonesia, the Philippines and Thailand as, $23 \%, 35 \%$ and $18 \%$, respectively, all of which seem excessively high to serve as warning levels. In contrast, the unaffected economies in the sample-Fiji and Taipei, China-did not experience domestic credit growth as rapid as the affected economies. 
Table 11: Domestic Credit Growth (\%)

\begin{tabular}{lrrrrrrr}
\hline \multicolumn{1}{c}{ Country } & $\mathbf{1 9 9 4}$ & $\mathbf{1 9 9 5}$ & $\mathbf{1 9 9 6}$ & $\mathbf{1 9 9 7}$ & $\mathbf{1 9 9 8}$ & $\mathbf{1 9 9 9}$ & $\mathbf{2 0 0 0}$ \\
Fiji & 4.05 & 1.17 & 3.93 & -10.12 & 3.76 & 4.29 & 5.74 \\
Indonesia & & & 23.01 & 42.05 & 28.71 & 23.96 & 25.45 \\
Philippines & 20.45 & 31.95 & 39.09 & 27.53 & -2.73 & 2.83 & \\
Taipei, China & & 10.45 & 7.86 & 8.53 & 7.86 & 3.40 & \\
Thailand & & 23.53 & 13.74 & 30.10 & -3.30 & -4.02 & -7.40 \\
\hline
\end{tabular}

Sources: Country Metadata and Authors' Calculations

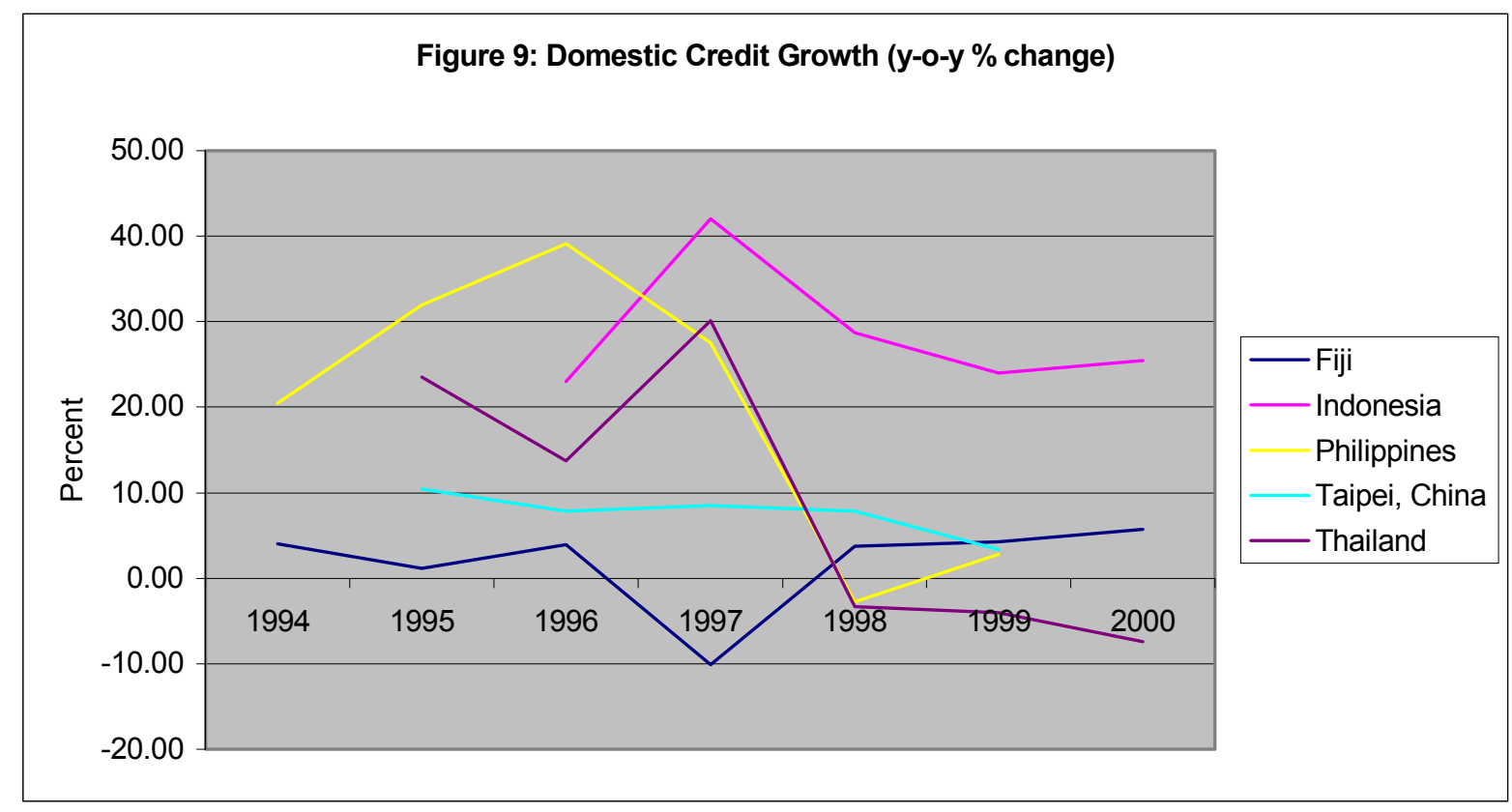

\section{Domestic Credit (\% of GDP)}

This variable is a variation of the preceding section. Because this MPI is expressed as a ratio, it gives an indication of the relative magnitude or scale of the increase in domestic credit in relation to the size of the economy.

A visual inspection of the behavior of this particular variable for the three affected economies reveals that the MPI reflecting domestic credit in percent of GDP tends to be a short leading or coincident indicator of periods of economic and financial vulnerability. 


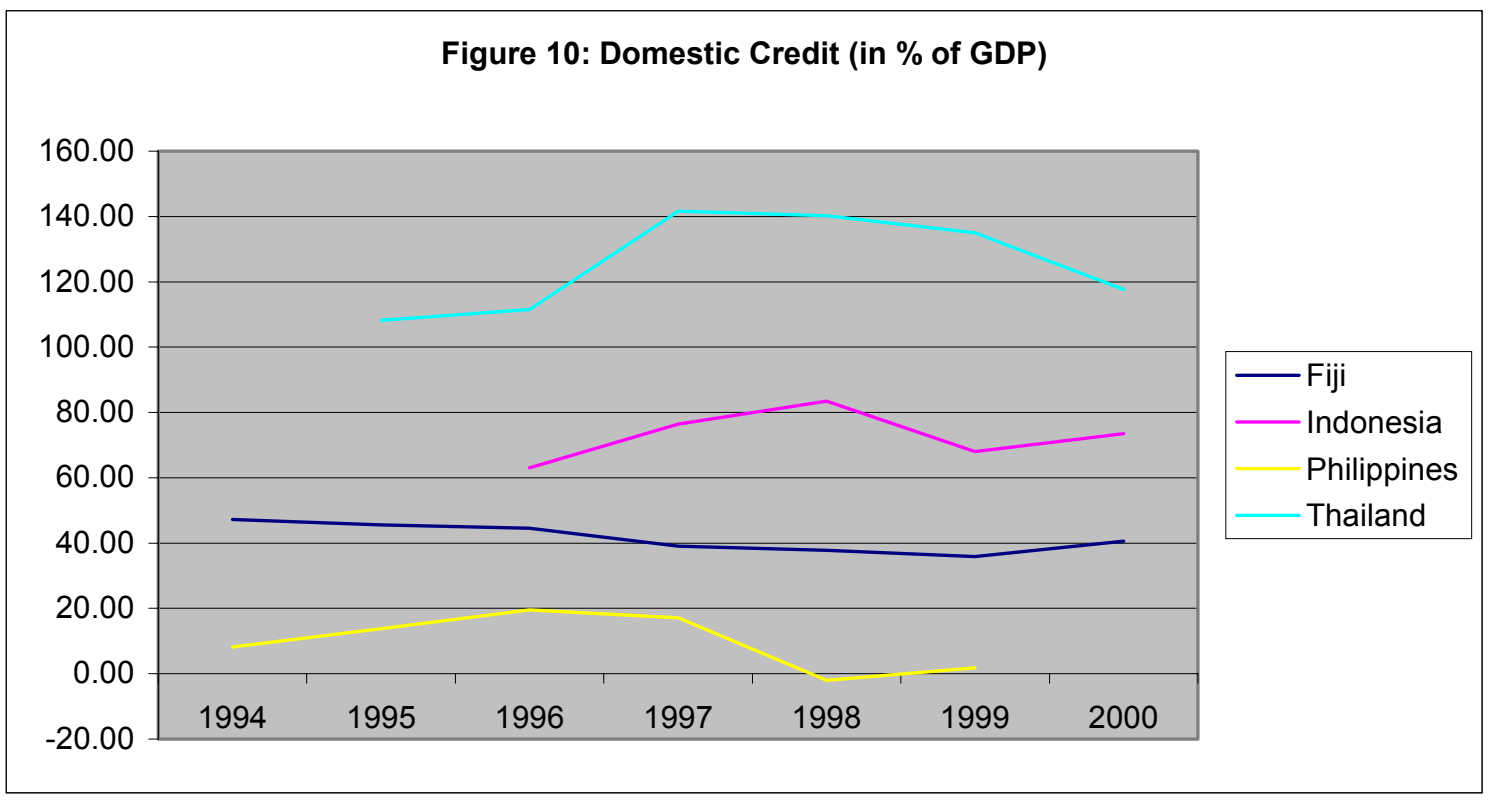

Table 13: Domestic Credit Growth (\% of GDP)

\begin{tabular}{lcrrrrrrr}
\hline Country & $\mathbf{1 9 9 4}$ & $\mathbf{1 9 9 5}$ & $\mathbf{1 9 9 6}$ & $\mathbf{1 9 9 7}$ & $\mathbf{1 9 9 8}$ & $\mathbf{1 9 9 9}$ & $\mathbf{2 0 0 0}$ & Benchmark \\
\hline Fiji & 47.19 & 45.58 & 44.57 & 39.09 & 37.82 & 35.82 & 40.64 & \\
Indonesia & & & 63.08 & 76.48 & 83.52 & 67.99 & 73.45 & 80.00 \\
Philippines & 8.24 & 13.77 & 19.51 & 17.11 & -1.96 & 1.77 & & 18.31 \\
$\begin{array}{l}\text { Taipei, China } \\
\text { Thailand }\end{array}$ & & & & & & & & \\
\hline
\end{tabular}

Sources: Country Metadata and ADB Website

As hindsight would suggest, domestic credit growth in percent of GDP reaching the average magnitudes of the period just before and during the Asian crisis of 1997-98 signal financial sector weakness in the affected economies of Indonesia, the Philippines and Thailand. For Indonesia, domestic credit as a percentage of GDP reached an average of about 80 percent in 1997 and 1998. Thailand, on the other hand, experienced an average figure of 140 percent during the same period. The corresponding Philippine figures were more moderate at 18 percent. One way of interpreting these figures is to consider them as the limits, as determined historically, beyond which the vulnerability degenerates rapidly into a possible crisis.

\section{Credit to Private Sector (\% of GDP)}

One feature of the recent Asian crisis was that the excessive money and credit expansion was directed mainly towards private sector borrowing (or borrowing) instead of financing public deficits. As a consequence, credit to private sector in percent of GDP should also be monitored. As a graphical analysis shows, this variable moves in tandem with domestic credit in percent of GDP. 
This variable in the pre-crisis period was at average levels of $70 \%, 15 \%$, and $133 \%$ for Indonesia, the Philippines and Thailand, respectively. Again, in contrast, the magnitude of this MPI in Fiji, an unaffected country, is very moderate compared to the aforementioned benchmarks.

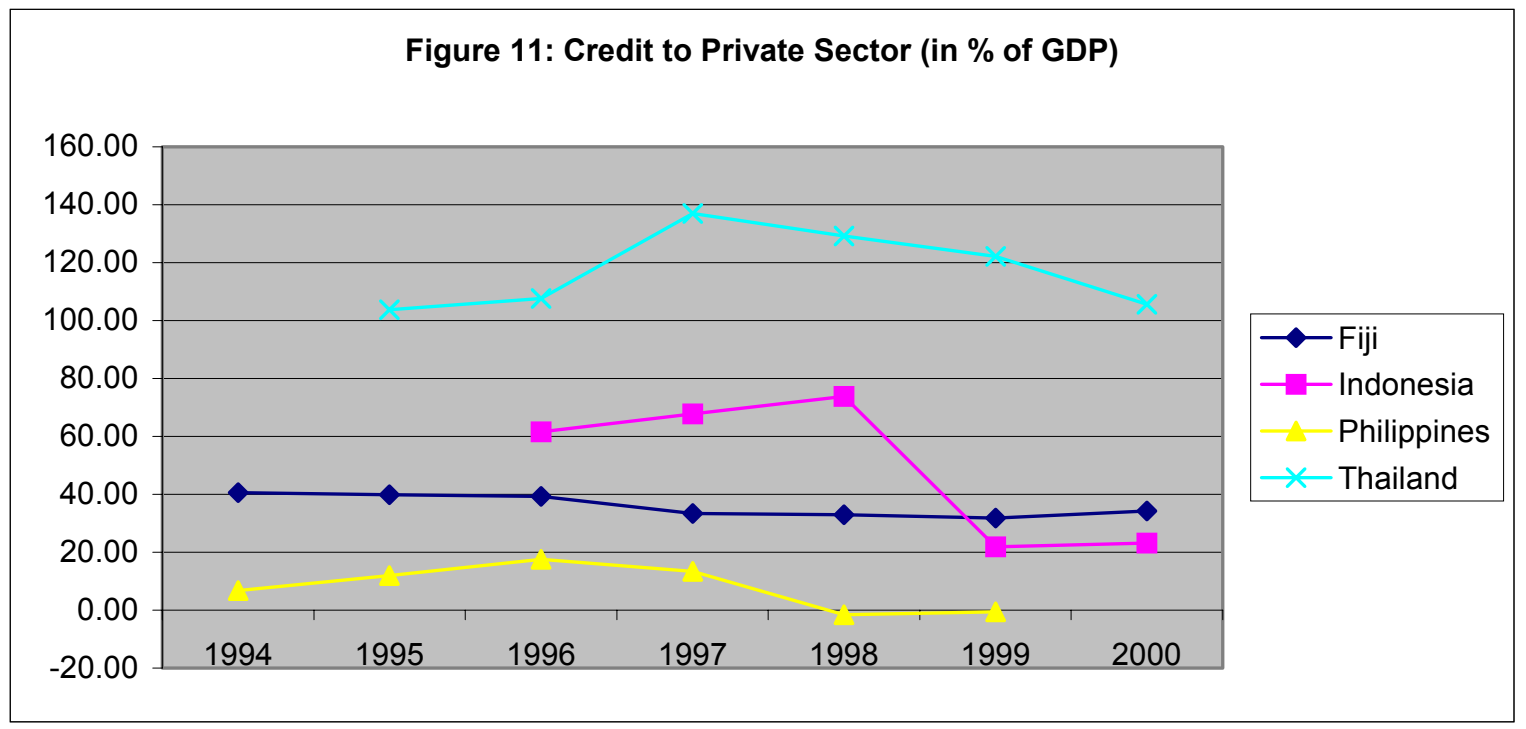

Table 14: Credit To Private Sector (\% of GDP)

\begin{tabular}{lcrrrrrr}
\hline Country & $\mathbf{1 9 9 4}$ & $\mathbf{1 9 9 5}$ & $\mathbf{1 9 9 6}$ & $\mathbf{1 9 9 7}$ & $\mathbf{1 9 9 8}$ & $\mathbf{1 9 9 9}$ & $\mathbf{2 0 0 0}$ \\
\hline Fiji & 40.59 & 39.87 & 39.30 & 33.37 & 32.91 & 31.87 & 34.27 \\
Indonesia & & & 61.60 & 67.78 & 73.86 & 21.92 & 23.21 \\
Philippines & 6.72 & 11.91 & 17.58 & 13.36 & -1.64 & -0.54 & \\
Taipei, China & & & & & & & \\
Thailand & & 103.71 & 107.60 & 136.97 & 129.22 & 122.22 & 105.60 \\
\hline
\end{tabular}

Sources: Country Metadata and ADB Website

\section{Banking}

The Asian crisis unmasked weaknesses in the banking systems in many of the affected Asian economies. In combination with increasing money and credit, a weak and poorly regulated banking system can easily lead to deterioration in the quality of credit. A condition of over investment in unproductive sectors of the economy can be the outcome of poor credit quality. Often times, the symptoms of a very liquid banking sector can be excessively high net bank profits, loans, international borrowings and real estate loans. 


\section{Net Bank Profits}

Since Fiji, Indonesia and Thailand express net bank profits as a percent of average assets as opposed to the Philippines where it is expressed as a ratio to total assets, analysis will then be made separately. Drawing the relationship between net bank profits and the extent of vulnerability of a financial system is not straightforward. On one hand, since declining bank profits may compromise the viability of a bank, it can be indicative of vulnerability. Thailand saw a deterioration of net bank profits as a percent of average assets prior to the onset of the crisis in 1997. The plunge in profits for the Indonesian banking system is a direct consequence of the widespread bank failures owing to the currency crisis. On the other hand, for the Philippines, net bank profits came from a high level prior to the crisis, and plunged down in the succeeding years.

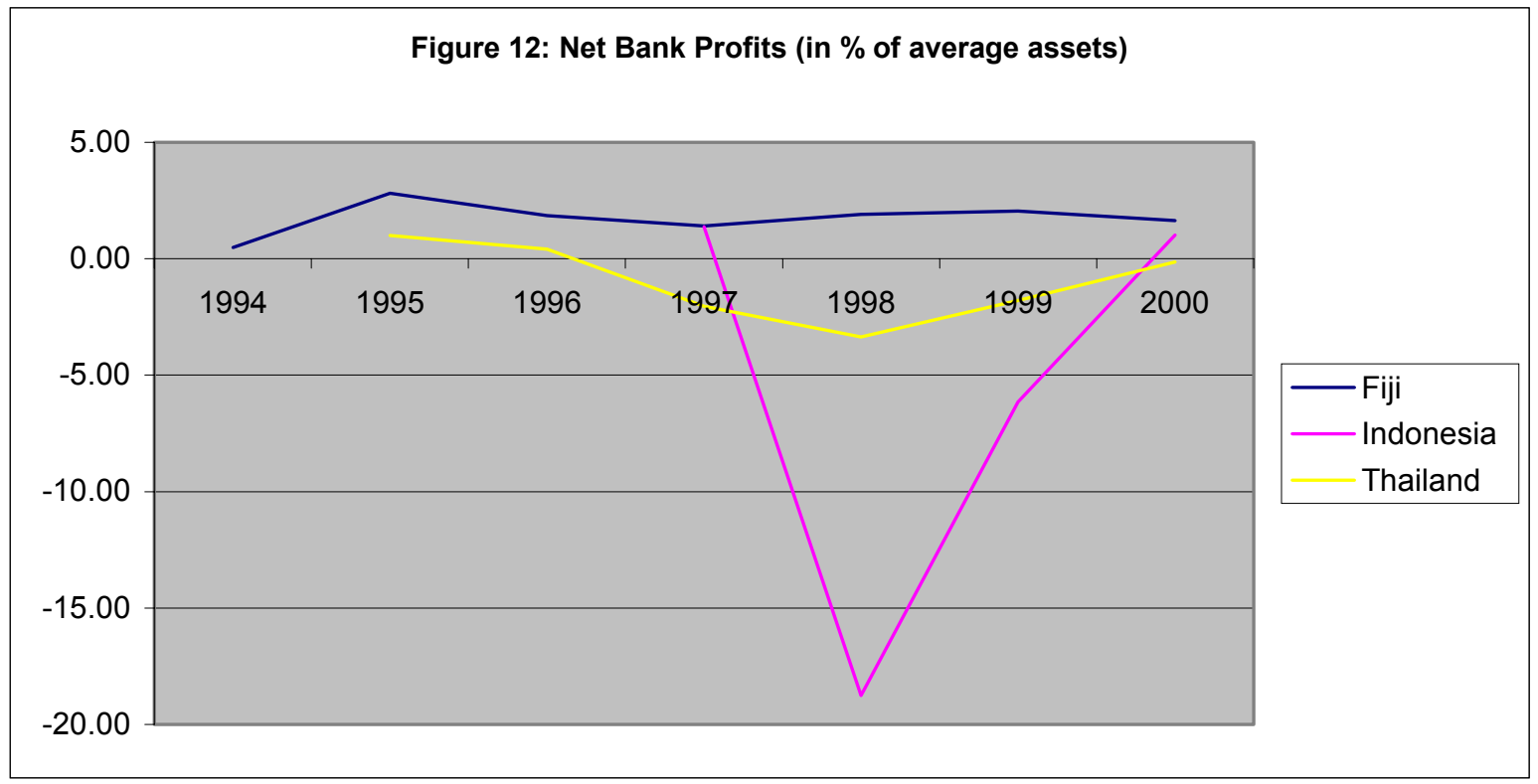




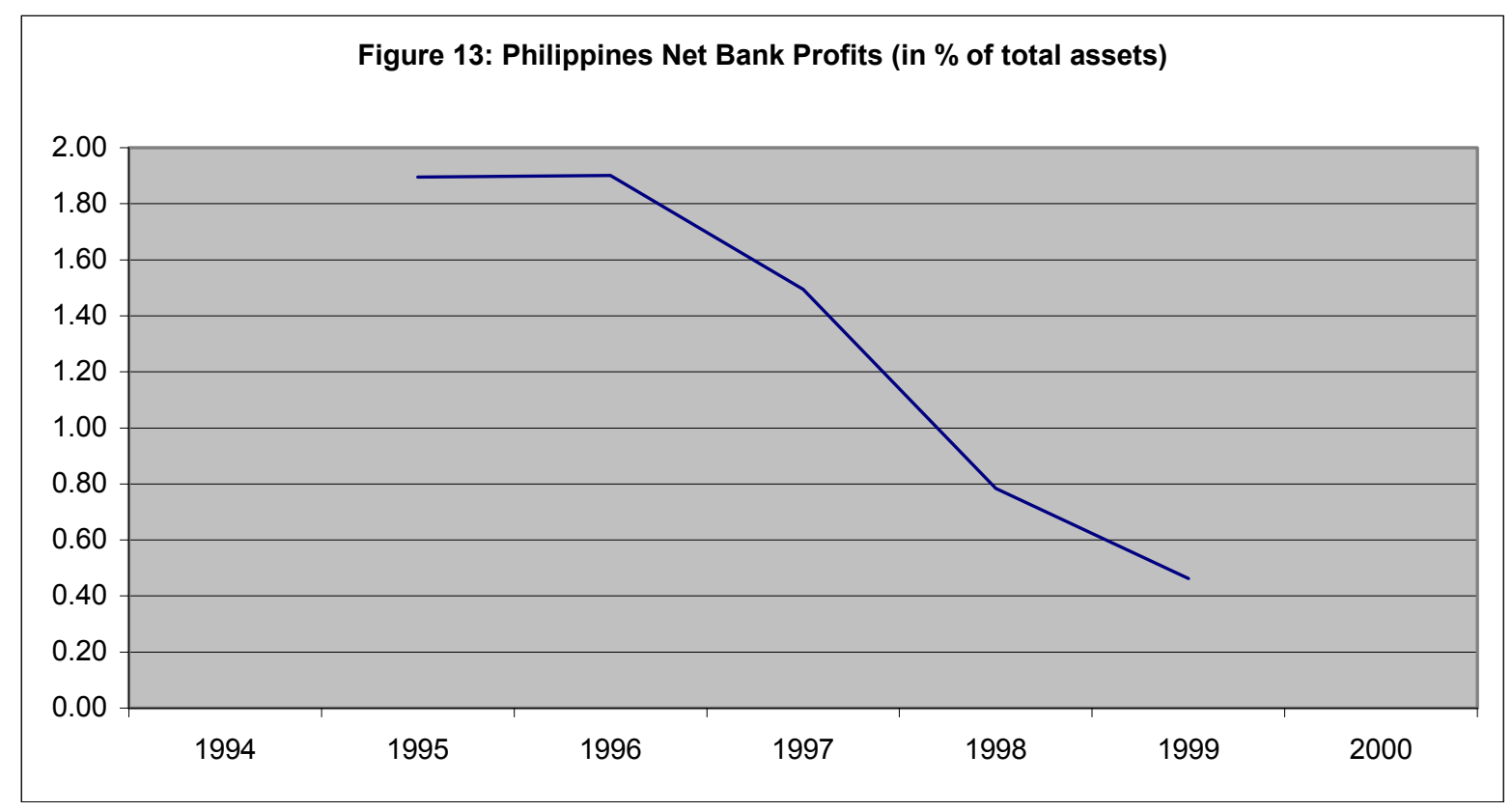

Table 14: Net Bank Profits

\begin{tabular}{lrrrrrrr}
\hline Country & $\mathbf{1 9 9 4}$ & $\mathbf{1 9 9 5}$ & $\mathbf{1 9 9 6}$ & $\mathbf{1 9 9 7}$ & $\mathbf{1 9 9 8}$ & $\mathbf{1 9 9 9}$ & $\mathbf{2 0 0 0}$ \\
\hline Fiji & 0.48 & 2.82 & 1.86 & 1.40 & 1.90 & 2.05 & 1.64 \\
Indonesia & & & & 1.37 & -18.76 & -6.14 & 1.01 \\
Philippines & & 1.90 & 1.90 & 1.49 & 0.78 & 0.46 & \\
Taipei & & & & & & & \\
Thailand & & 1.00 & 0.42 & -2.05 & -3.35 & -1.80 & -0.14 \\
\hline
\end{tabular}

Sources: Country Metadata and ADB Website

\section{Total Bank Loans (\% of Total Deposits)}

Across all the affected economies among the RETA participating countries, there is the observation that the extent of net bank loans was probably excessive prior to the outbreak of the crisis. Hence, this variable may prove to be a useful leading indicator of financial and currency vulnerability. Indonesia's total bank loans as percent of total deposits was conspicuously higher during the pre-crisis years; the Philippines, although to a lesser magnitude, shows the same trend.

It is logical to relate the positive relationship between total bank loans (as percentage of total deposits) and extent of vulnerability of the financial system. The historical record bears the fact that Indonesia could not sustain the pre-crisis average of 78 percent total bank loans to deposits. The corresponding levels for the Philippines and Thailand were $105 \%$ t and $131 \%$, respectively. 


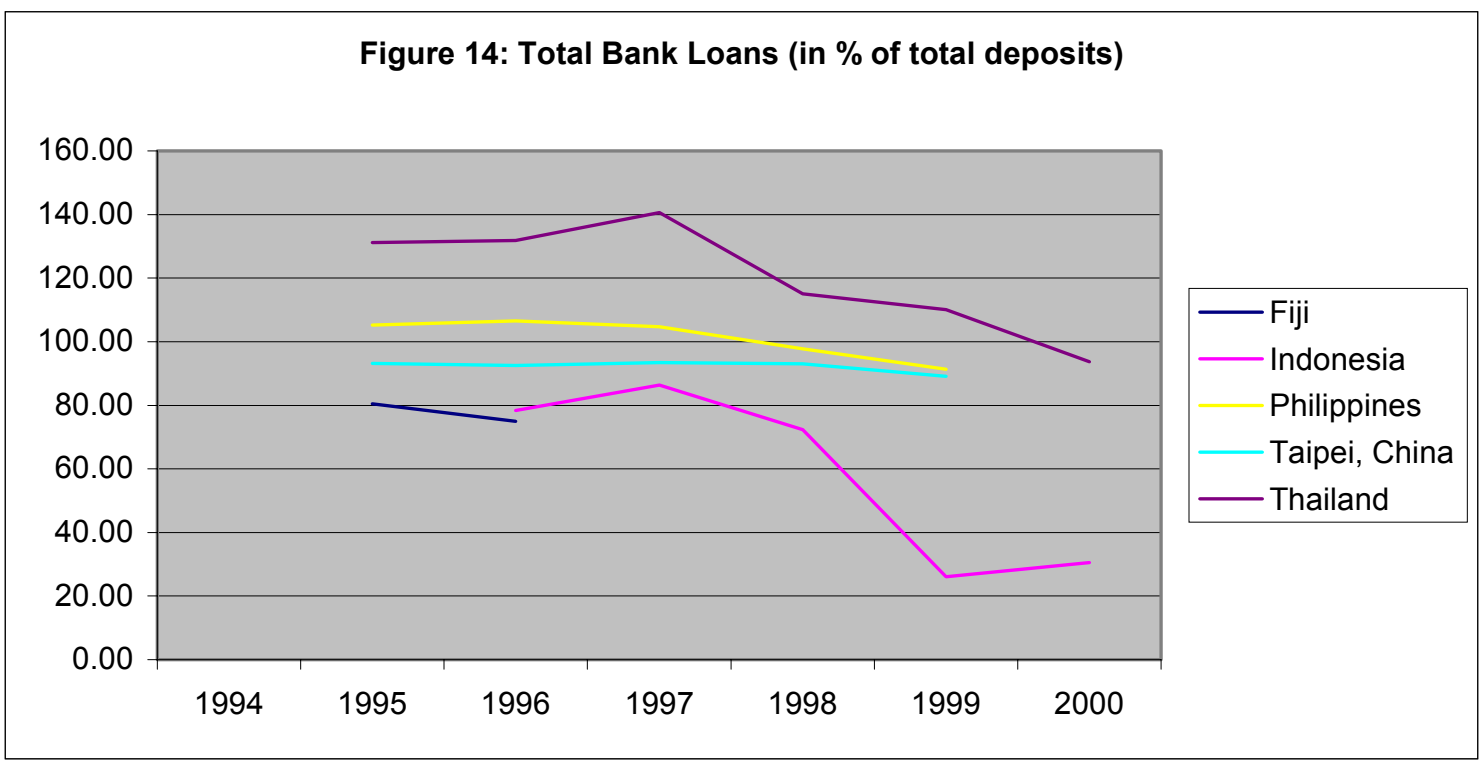

Table 15: Total Bank Loans (in \% of total deposits)

\begin{tabular}{|c|c|c|c|c|c|c|c|}
\hline Country & 1994 & 1995 & 1996 & 1997 & 1998 & 1999 & 2000 \\
\hline Fiji & & 80.52 & 74.91 & & & & \\
\hline Indonesia & & & 78.31 & 86.38 & 72.39 & 26.03 & 30.52 \\
\hline Philippines & & 105.24 & 106.49 & 104.73 & 97.75 & 91.30 & \\
\hline Taipei, China & & 93.17 & 92.51 & 93.44 & 93.02 & 89.11 & \\
\hline Thailand & & 131.23 & 131.76 & 140.62 & 115.04 & 110.08 & 93.71 \\
\hline
\end{tabular}

Sources: Country Metadata and ADB Website

\section{International Borrowings with Maturities One Year and Less}

Because of the different sizes of the economies in the sample, this variable, as measured in absolute levels, cannot be compared across different economies. Economies have different production capacities, financial sector development, and hence, may differ in their demand for foreign borrowing. It necessarily follows that this variable has to be analyzed on a country-specific basis.

For Indonesia and Thailand, international borrowings with maturities one year and less were definitely at a high point prior to the 1997 crisis. In 1997, Indonesia's foreign borrowing was more than US\$8.0 billion. The magnitude for Thailand is even more dramatic; in 1995 its foreign borrowings was close to US\$16.0 billion. With the benefit of hindsight, short-term international borrowings (with maturities one year and less) reaching these high levels may be a cause for alarm.

For the Philippines, the behavior of the variable is not as clear-cut compared to the other economies. There appears to be little difference in the magnitudes of the shortterm international borrowings between the pre- and post-crisis periods. 

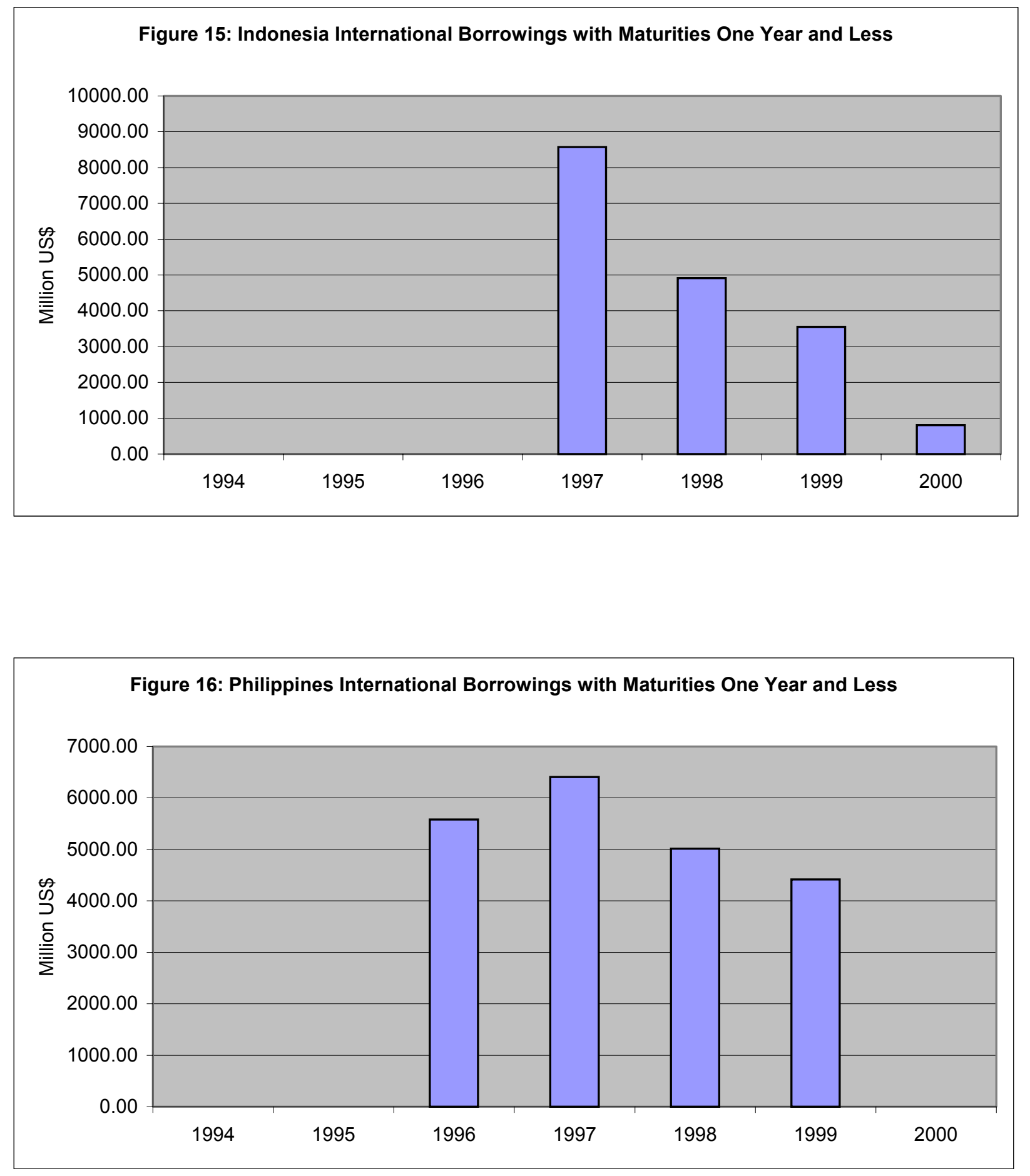

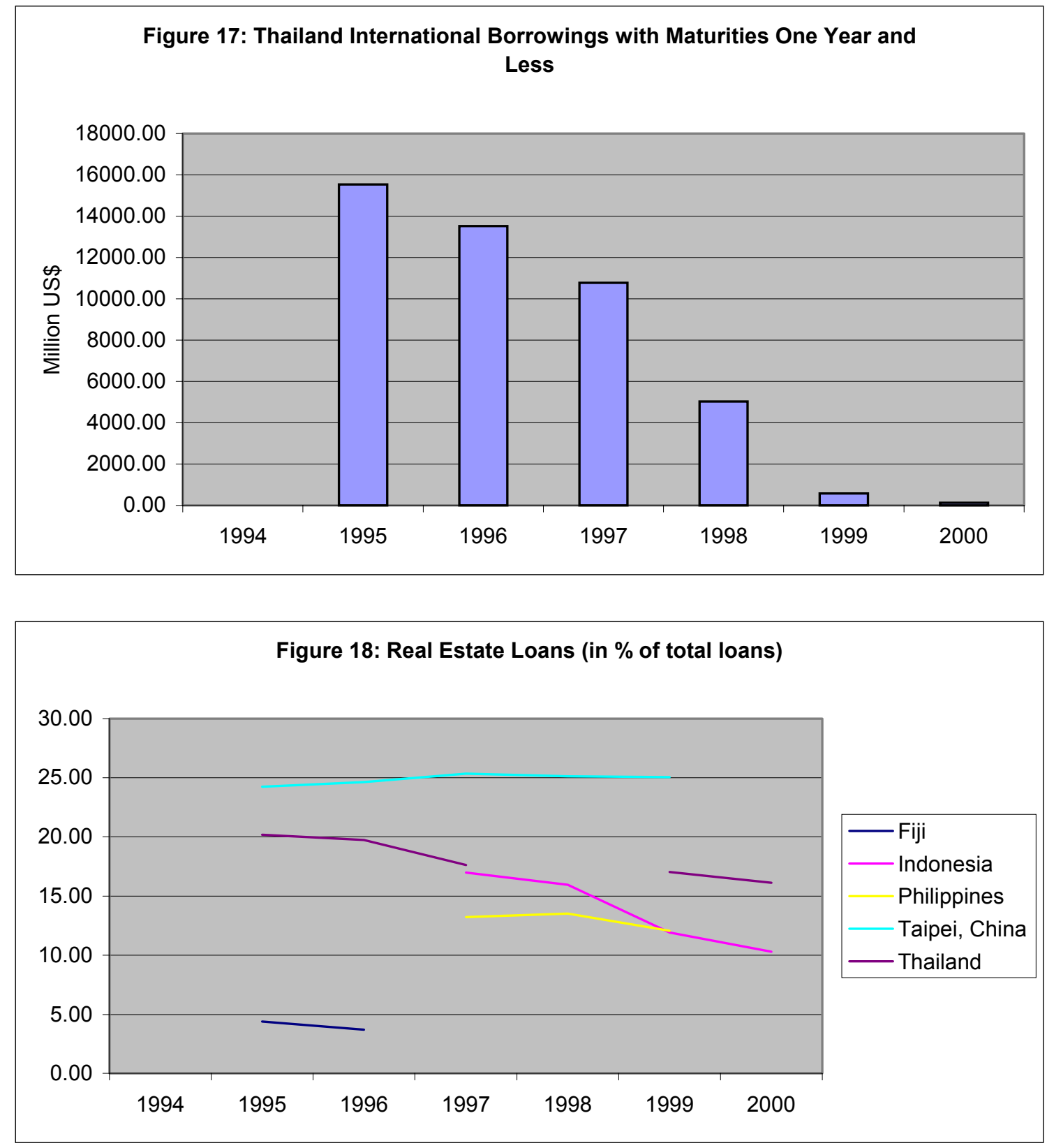

Table 16: International Borrowings with Maturities One Year and Less (Mn US\$)

\begin{tabular}{|c|c|c|c|c|c|c|c|}
\hline Country & 1994 & 1995 & 1996 & 1997 & 1998 & 1999 & 2000 \\
\hline \multicolumn{8}{|l|}{ Fiji } \\
\hline Indonesia & & & & 8573.42 & 4909.90 & 3553.77 & 805.64 \\
\hline Philippines & & & 5584.00 & 6406.00 & 5016.00 & 4418.00 & \\
\hline \multicolumn{8}{|l|}{ Taipei, China } \\
\hline Thailand & & 15541.46 & 13525.24 & 10776.80 & 5028.79 & 576.28 & 132.17 \\
\hline
\end{tabular}

Sources: Country Metadata and ADB Website 


\section{Real Estate Loans (\% of Total Loans)}

The banking sectors of the affected economies exhibited high levels of exposure to real estate loans prior to the crisis. Peak magnitudes of real estate loans were 1997 for Indonesia and the Philippines and 1996 for Thailand.

Table 17: Real Estate Loans (\% of Total Loans)

\begin{tabular}{|c|c|c|c|c|c|c|c|}
\hline Country & 1994 & 1995 & 1996 & 1997 & 1998 & 1999 & 2000 \\
\hline Fiji & & 4.38 & 3.69 & & & & \\
\hline Indonesia & & & & 16.97 & 15.94 & 11.91 & 10.30 \\
\hline Philippines & & & & 13.22 & 13.51 & 12.05 & \\
\hline Taipei, China & & 24.23 & 24.62 & 25.32 & 25.11 & 25.04 & \\
\hline Thailand & & 20.17 & 19.72 & 17.62 & & 17.03 & 16.11 \\
\hline
\end{tabular}

Sources: Country Metadata and ADB Website

\section{Interest Rates}

\section{Money Market Rate/Interbank Rate (Average of Period)}

A sharp increase in this rate signals tight liquidity in the banking system, which can worsen the incidence of Non Performing Loans (NPLs). In that sense, this indicator can be said to be a leading indicator or possess an early warning characteristic particularly for banking problems. Threshold levels for these values should be on a country-specific basis as the magnitudes for interest rates show large variances across economies.

With the exception of the Philippines, this variable or indicator is in accord with theory, albeit with the indicator showing more of a coincident nature rather than leading. Hence, monitoring this variable is useful in assessing the over-all health of the economy, especially for Indonesia and Thailand.

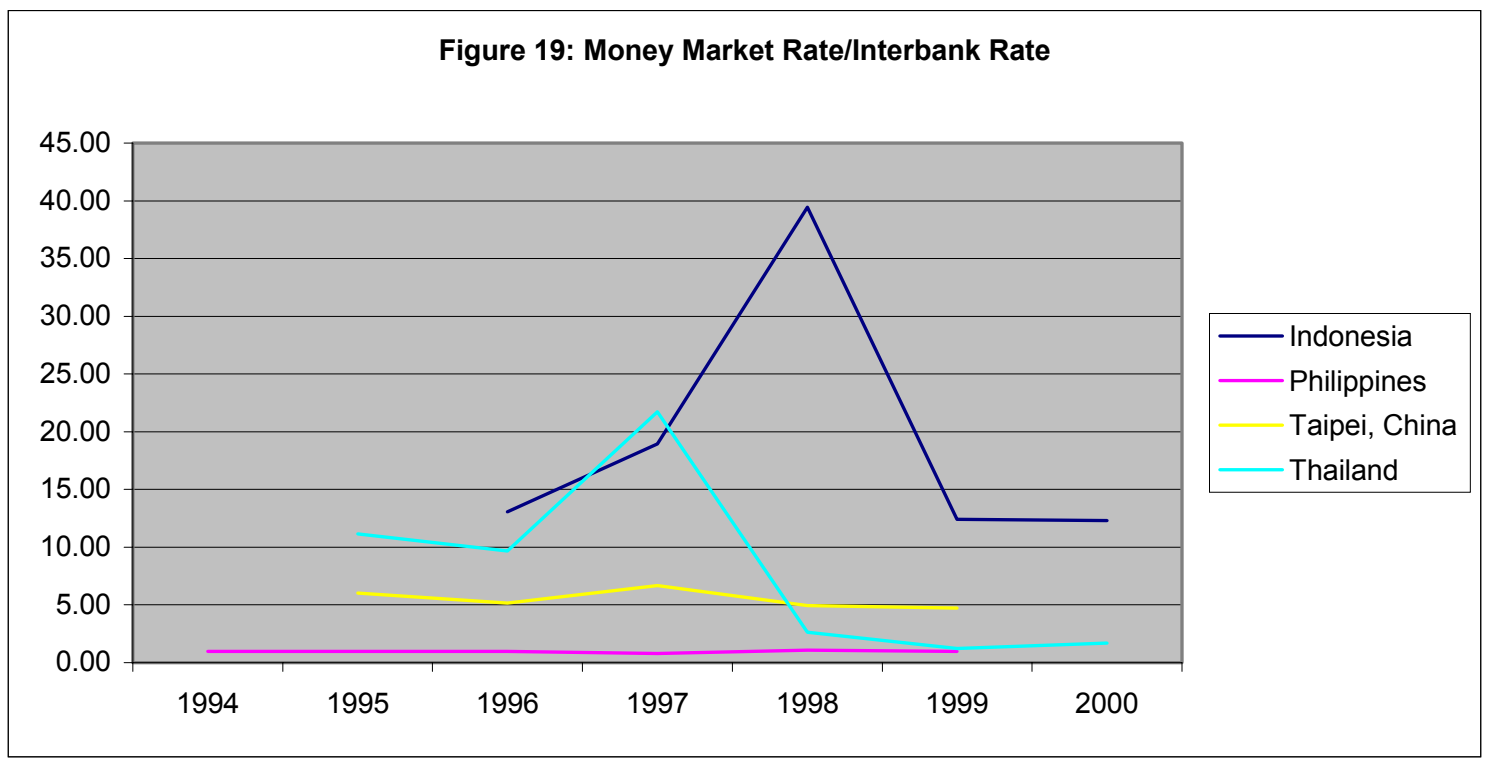


Table 18: Money Market Rate/Interbank Rate (Average of Period)

\begin{tabular}{|c|c|c|c|c|c|c|c|}
\hline Country & 1994 & 1995 & 1996 & 1997 & 1998 & 1999 & 2000 \\
\hline \multicolumn{8}{|l|}{ Fiji } \\
\hline Indonesia & & & 13.05 & 18.94 & 39.45 & 12.40 & 12.30 \\
\hline Philippines & 0.96 & 0.96 & 0.99 & 0.81 & 1.08 & 0.99 & \\
\hline Taipei, China & & 6.04 & 5.15 & 6.67 & 4.95 & 4.73 & \\
\hline Thailand & & 11.15 & 9.66 & 21.73 & 2.63 & 1.23 & 1.70 \\
\hline
\end{tabular}

Sources: Country Metadata and ADB Website

\section{Stock Market and Bonds}

Stock market developments signal changes in market perceptions of capital investors. A steep decline in stock prices-which as a rule is also combined with a sharp drop of market capitalization (\% of GDP)—signals weakness in the capital markets which may spread sooner or later to the real sector of the economy, thus posing the danger to set in force a cumulative downward spiral. Indicators such as the composite stock price index and the market capitalization as a percentage of GDP are generally accepted leading indicators for financial markets. The same can be said for the Stock PER. If this indicator is already high and increases further, this may signal an increasing stock asset inflation, which may lead to an asset bubble. On the other hand, if the stock market index is on the decline, this may consider as a harbinger of lower growth or recessionary pressures.

\section{Composite Stock Price Index (Capital City, National Currency Unit)}

Looking at the composite stock price index data of Indonesia, the shock waves emanating form the 1997 debacle are evident. The index fell sharply from 1996 to 1997. The movement of the composite stock price index in the Philippines is consistent with a bubble (in hindsight). An unusually high index preceded the currency crisis of 1997 . In Thailand, the index was at its peak in 1995, declining significantly in 1996 and on the crisis year itself.

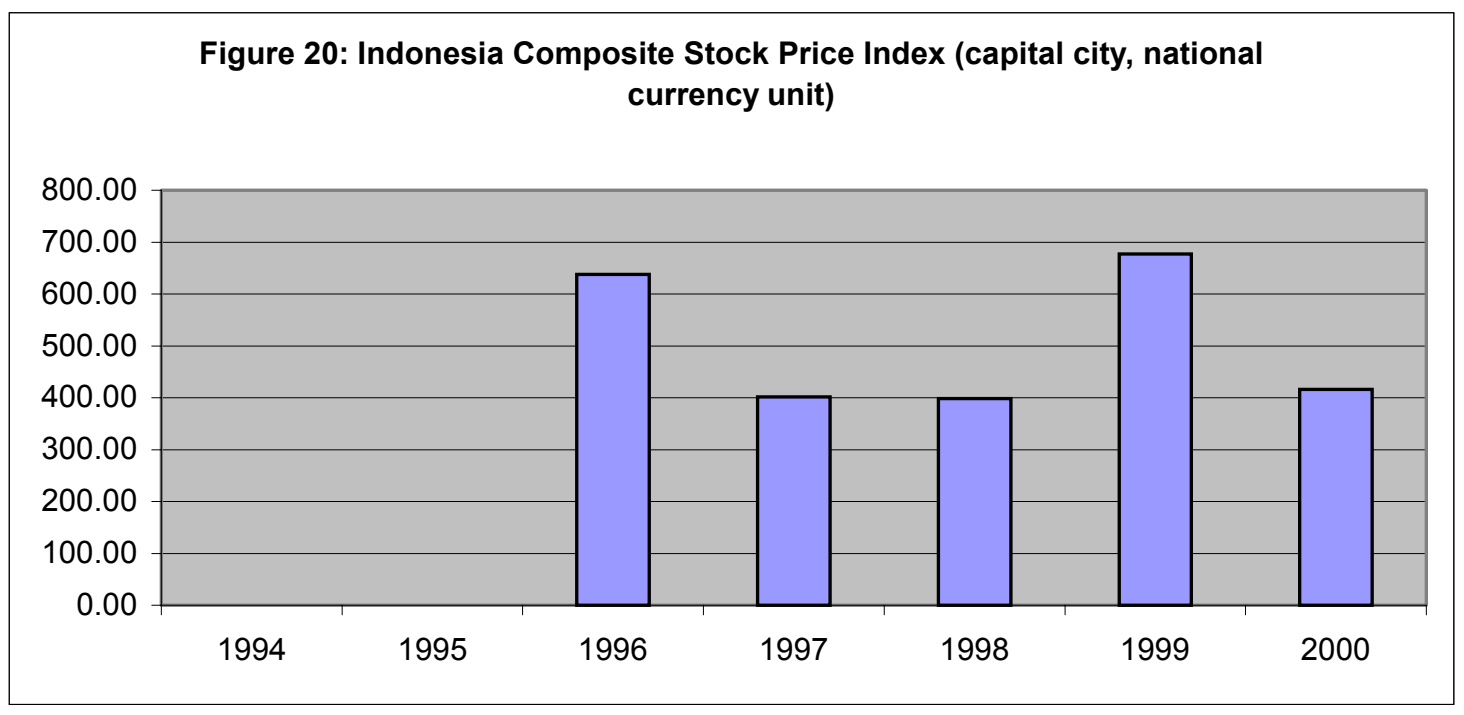




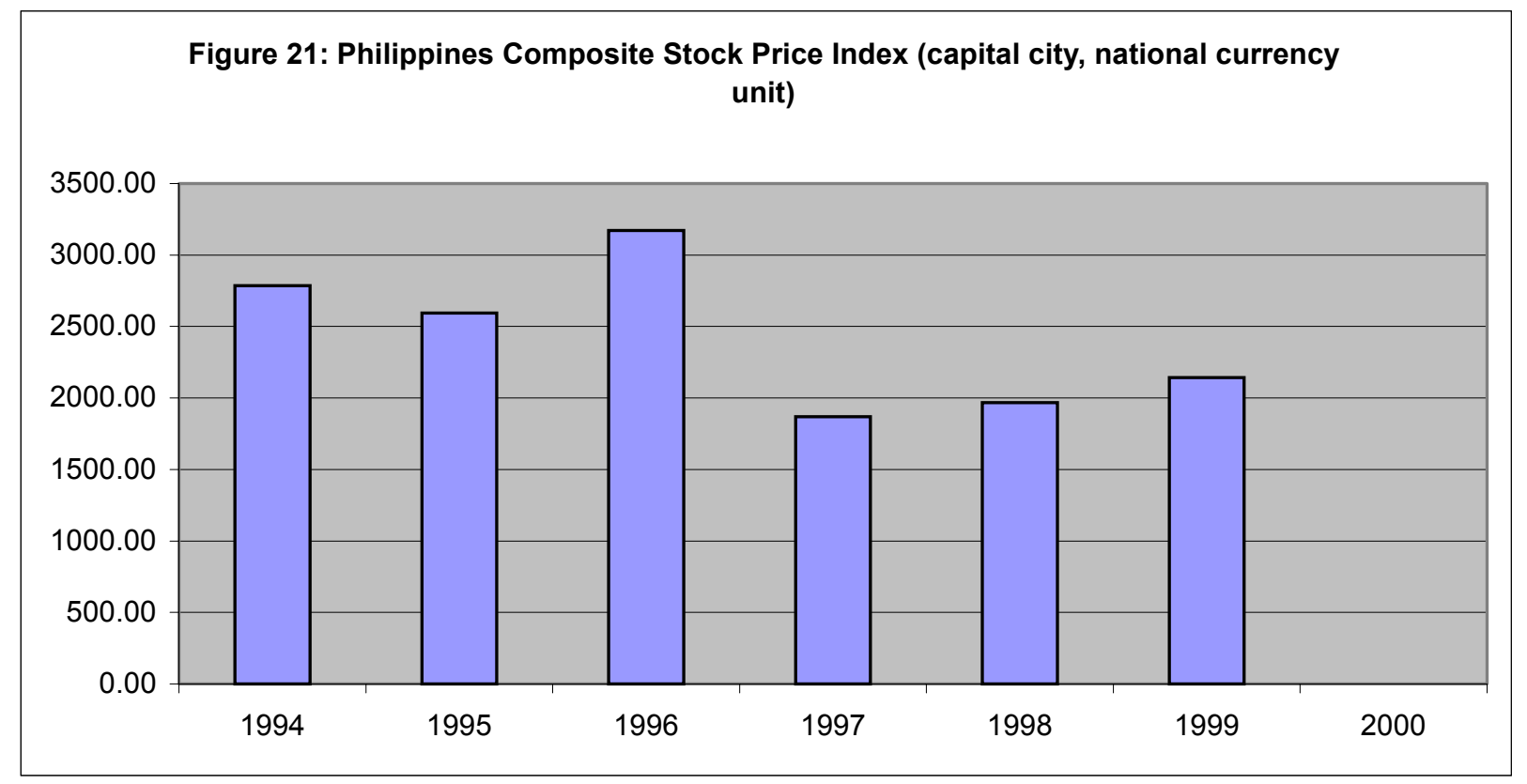

Figure 22: Taipei, China Composite Stock Price Index (capital city, national currency unit)

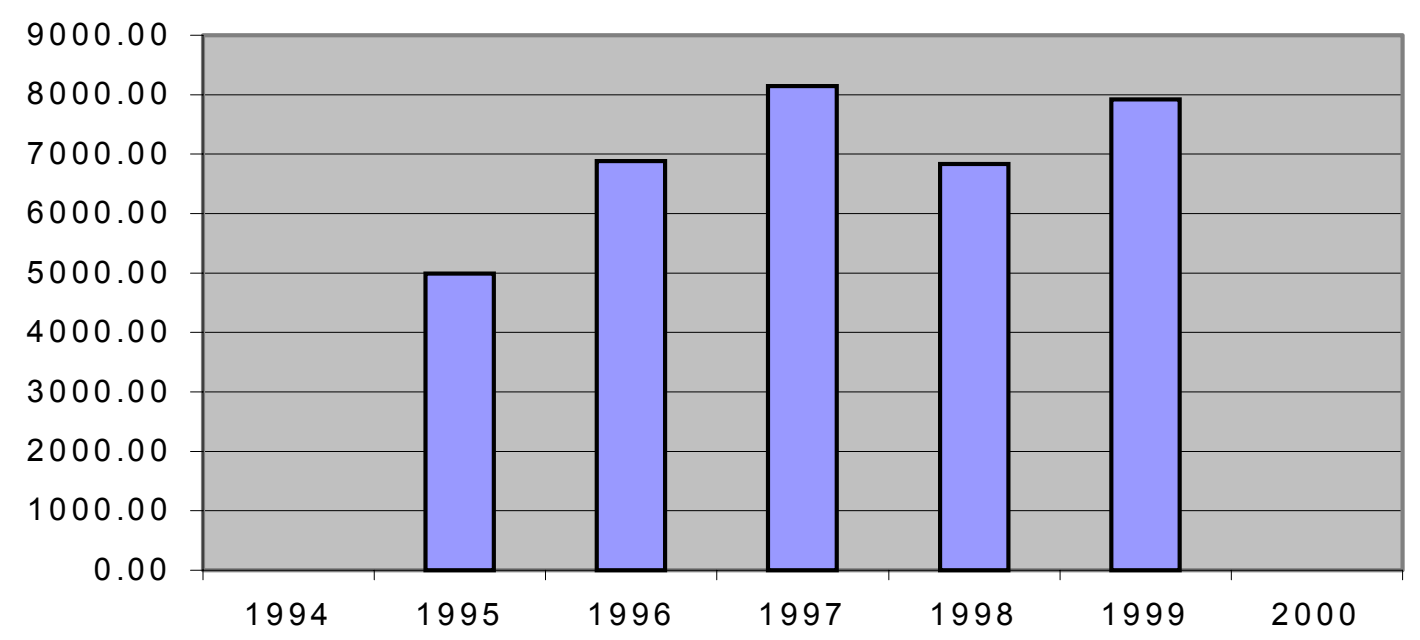




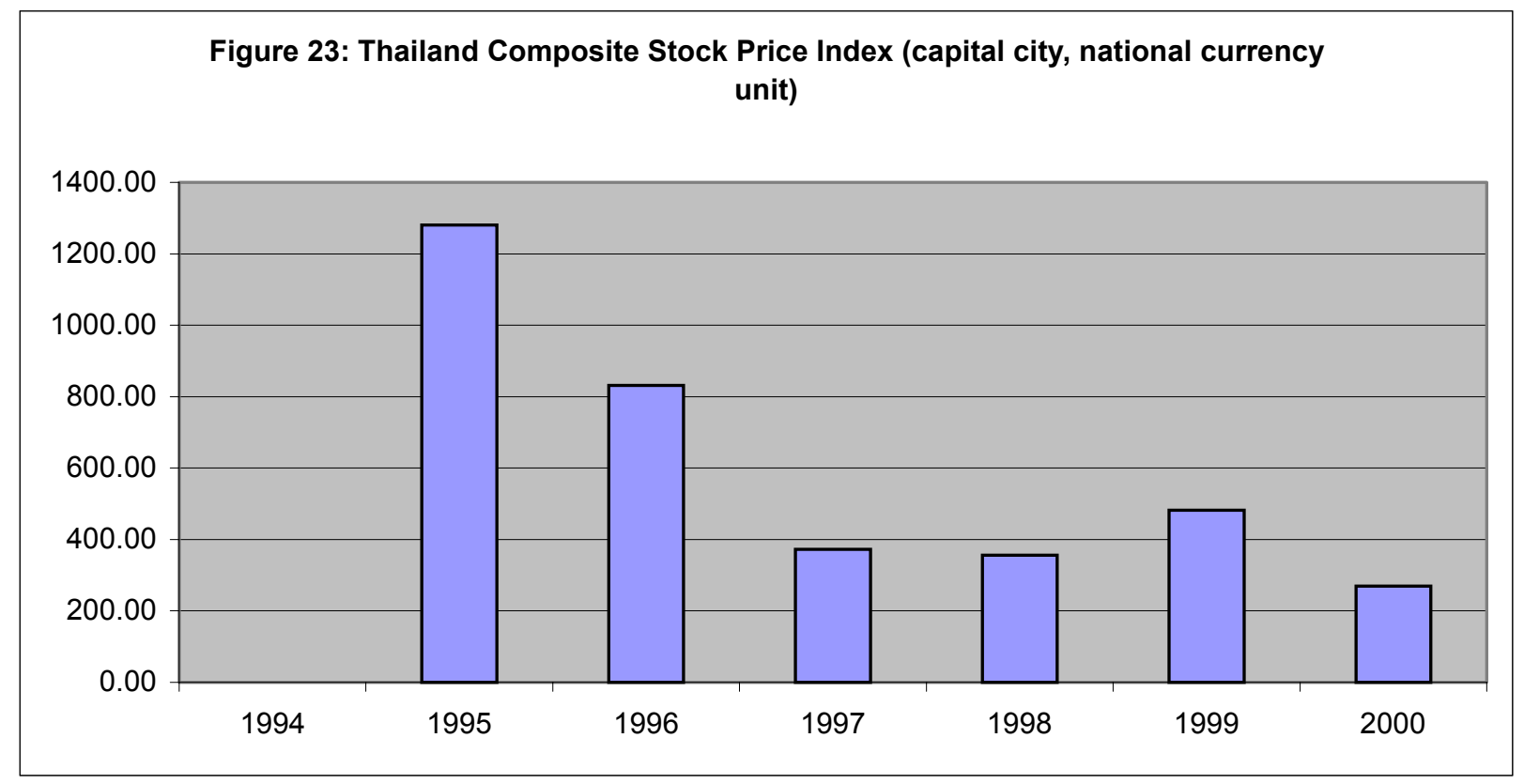

Table 19: Composite Stock Price Index (Capital City, National Currency Unit)

\begin{tabular}{|c|c|c|c|c|c|c|c|}
\hline Country & 1994 & 1995 & 1996 & 1997 & 1998 & 1999 & 2000 \\
\hline \multicolumn{8}{|l|}{$\overline{F i j i}$} \\
\hline Indonesia & & & 637.43 & 401.71 & 398.03 & 676.92 & 416.32 \\
\hline Philippines & 2785.81 & 2594.18 & 3170.56 & 1869.20 & 1968.80 & 2142.97 & \\
\hline Taipei, China & & 4988.83 & 6881.57 & 8147.84 & 6832.09 & 7918.93 & \\
\hline Thailand & & 1280.81 & 831.57 & 372.69 & 355.81 & 481.92 & 269.19 \\
\hline
\end{tabular}

Sources: Country Metadata and ADB Website

\section{Market Capitalization (\% of GDP)}

Of the crisis-hit economies, only the Philippines and Thailand have data on this indicator. As mentioned previously, movements in the composite stock price index and market capitalization move in tandem. Hence, as the composite stock price index goes down, it expected that market capitalization would also go down, and vice versa.

In both the Philippines and Thailand, the indicator is relatively high prior to the crash, indicating that the market capitalization rate might be taken as a signal of an asset bubble. It should be noted that identifying the presence of a bubble is quite difficult. Again, in hindsight, the rapidly increasing capitalization of the stock markets appears to be a result of asset inflation rather than simply robust growth of the stock markets. 


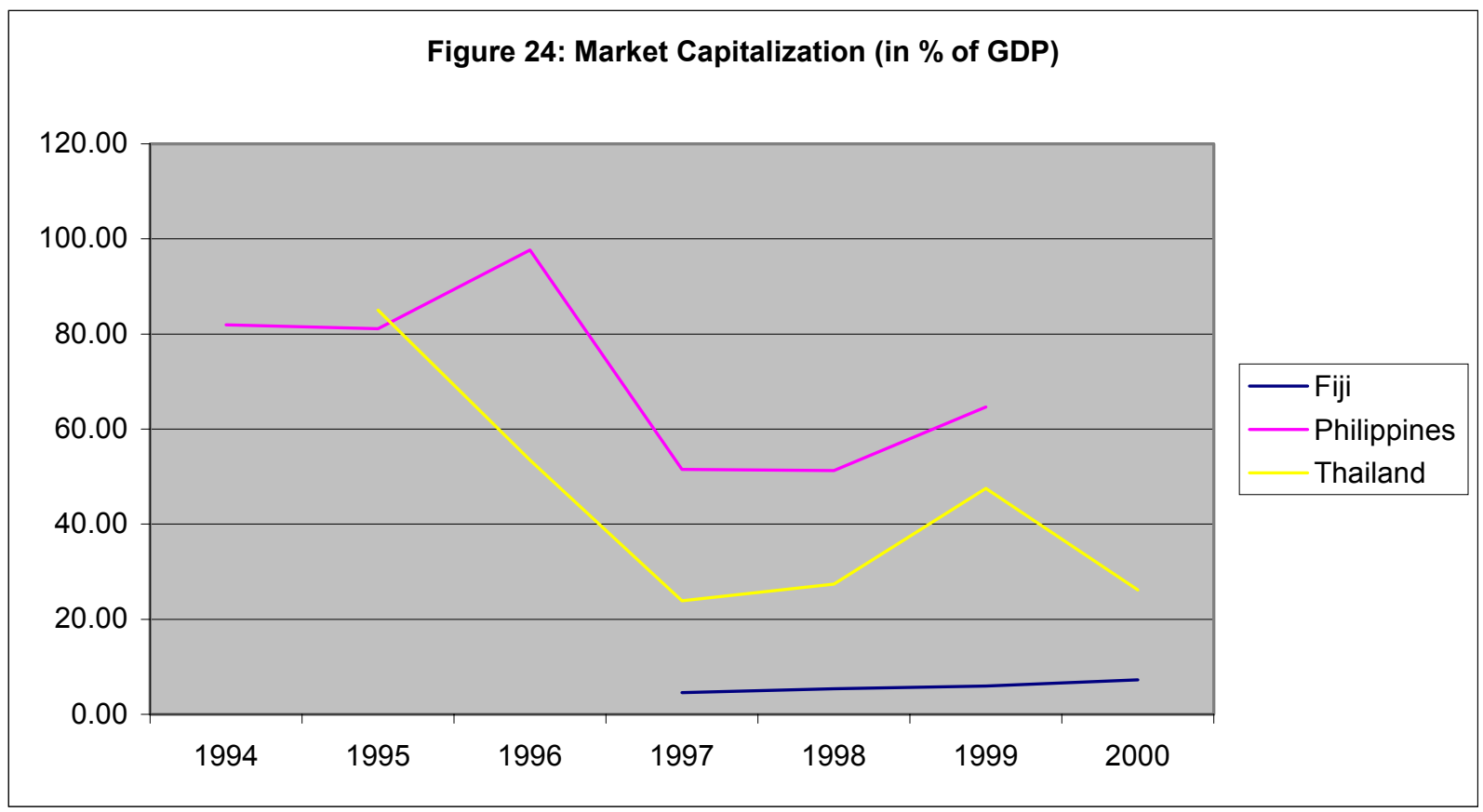

Table 20: Market Capitalization (\% of GDP)

\begin{tabular}{lcrrrrrr}
\hline Country & 1994 & $\mathbf{1 9 9 5}$ & $\mathbf{1 9 9 6}$ & $\mathbf{1 9 9 7}$ & $\mathbf{1 9 9 8}$ & $\mathbf{1 9 9 9}$ & $\mathbf{2 0 0 0}$ \\
\hline $\begin{array}{l}\text { Fiji } \\
\text { Indonesia }\end{array}$ & & & & 4.54 & 5.37 & 5.96 & 7.26 \\
$\begin{array}{l}\text { Philippines } \\
\begin{array}{l}\text { Taipei, China } \\
\text { Thailand }\end{array}\end{array}$ & 81.90 & 81.10 & 97.66 & 51.56 & 51.29 & 64.67 & \\
\hline
\end{tabular}

Sources: Country Metadata and ADB Website

\section{Stock Price Earning Ratio}

Theoretically, this indicator also follows the dynamics of the previous two indicators. A very high Price Earning Ratio (PER) may suggest that the stock is overvalued or that there may be rampant speculation in the market. The stock price earning ratios for Indonesia and Thailand, respectively, are 15.69 and 19.75, which, however, are not exceptionally high compared to other markets. 
Figure 25: Stock Price Earning Ratio

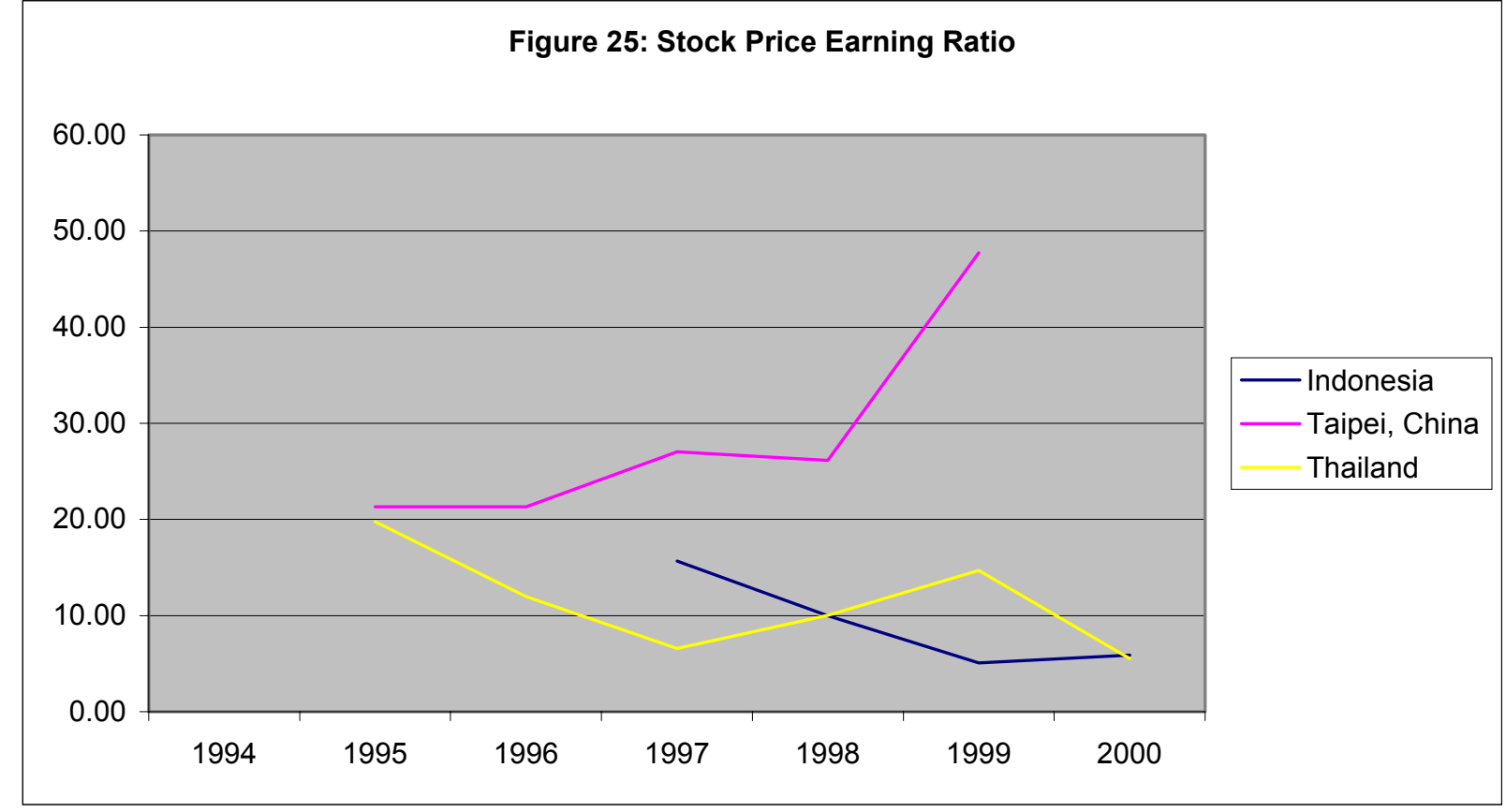

\section{Trade Exchange and International Reserves}

If real appreciation of a currency is not backed by corresponding productivity gains in the real economy, the economy could suffer from a loss of international competitiveness, rendering it increasingly vulnerable to external shocks.

On the other hand, a low and further declining amount of international reserves (central bank and the financial sector as a whole) signals possible problems of a country to meet international payments requirements, specifically import and debt payments. It is an indicator of current liquidity. Thus, this series is monitored closely by capital market investors as one of the most important early warning indicators of financial vulnerability.

\section{Real Effective Exchange Rate (REER)}

As mentioned earlier, very high REER can indicate that a country may not be as competitive relative to other countries. With a graphical inspection of the movement of this MPI for Fiji, the Philippines, Thailand and Viet Nam show high magnitudes of this indicator just prior to the crisis of 1997-1998. The loss in competitiveness would render the economies more vulnerable to shocks.

Being a leading indicator, the pre-crisis period averages might be used as benchmarks for each of the countries. It is impossible to set a regional benchmark for this variable due to differences in initial conditions per country; hence, a country-specific benchmark should instead be presented.

For Fiji, the Philippines, and Thailand, the average pre-crisis levels are 114, 87, and 104, respectively. Among these, only the rapid rise in the rate in the Philippines provides any sort of clear signal. 
Table 21: Real Effective Exchange Rate

\begin{tabular}{lrrrrrrr}
\hline \multicolumn{1}{c}{ Country } & $\mathbf{1 9 9 4}$ & $\mathbf{1 9 9 5}$ & $\mathbf{1 9 9 6}$ & $\mathbf{1 9 9 7}$ & $\mathbf{1 9 9 8}$ & $\mathbf{1 9 9 9}$ & $\mathbf{2 0 0 0}$ \\
\hline $\begin{array}{l}\text { Fiji } \\
\text { Indonesia }\end{array}$ & 115.05 & 114.76 & 114.17 & 115.62 & 99.02 & 97.60 & 97.36 \\
$\begin{array}{l}\text { Philippines } \\
\text { Taipei, China }\end{array}$ & 79.57 & 84.30 & 91.54 & 88.08 & 69.51 & 74.50 & \\
$\begin{array}{l}\text { Thailand } \\
\text { Viet Nam }\end{array}$ & & & & & & & \\
\hline
\end{tabular}

Sources: Country Metadata and ADB Website
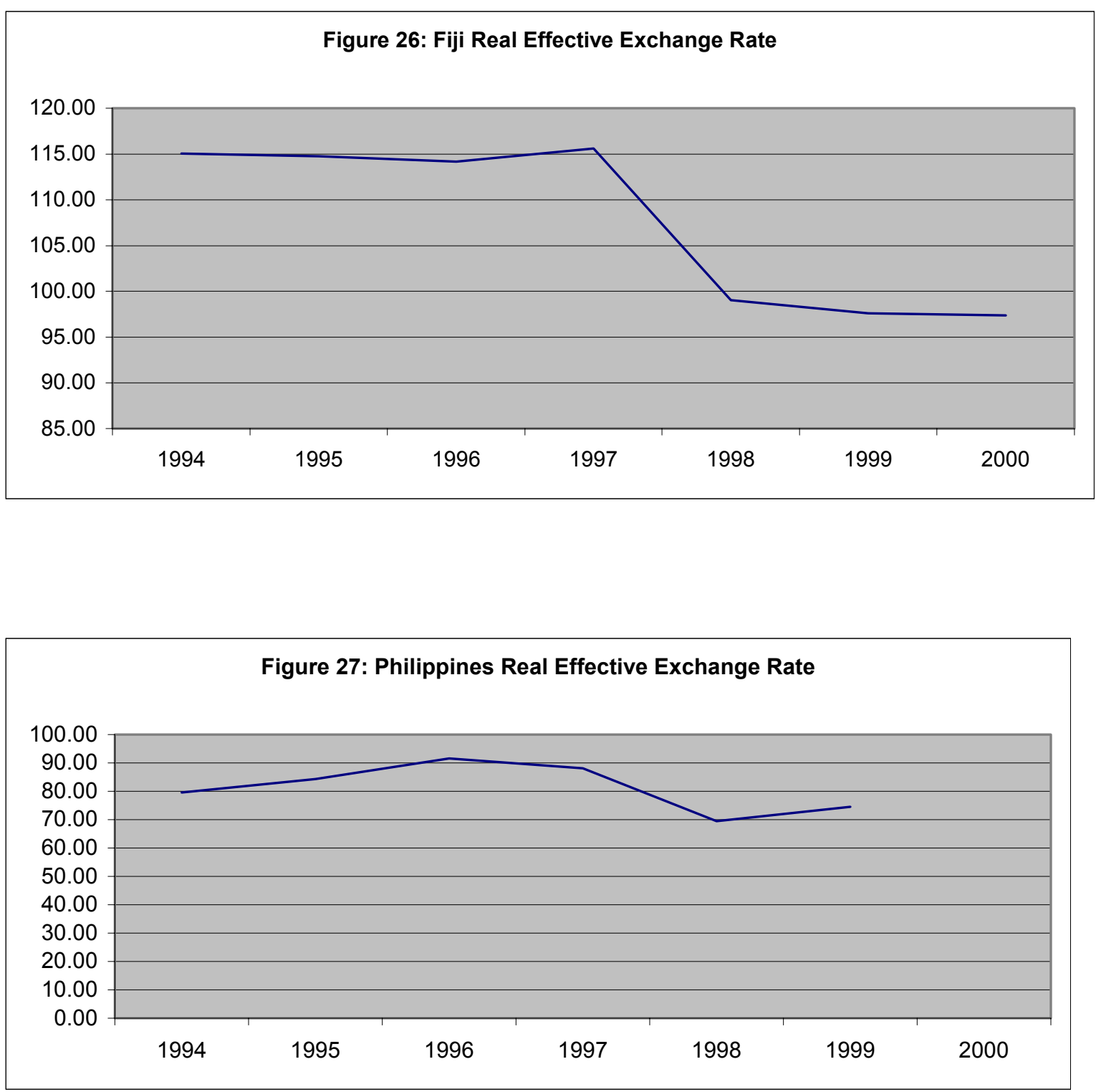

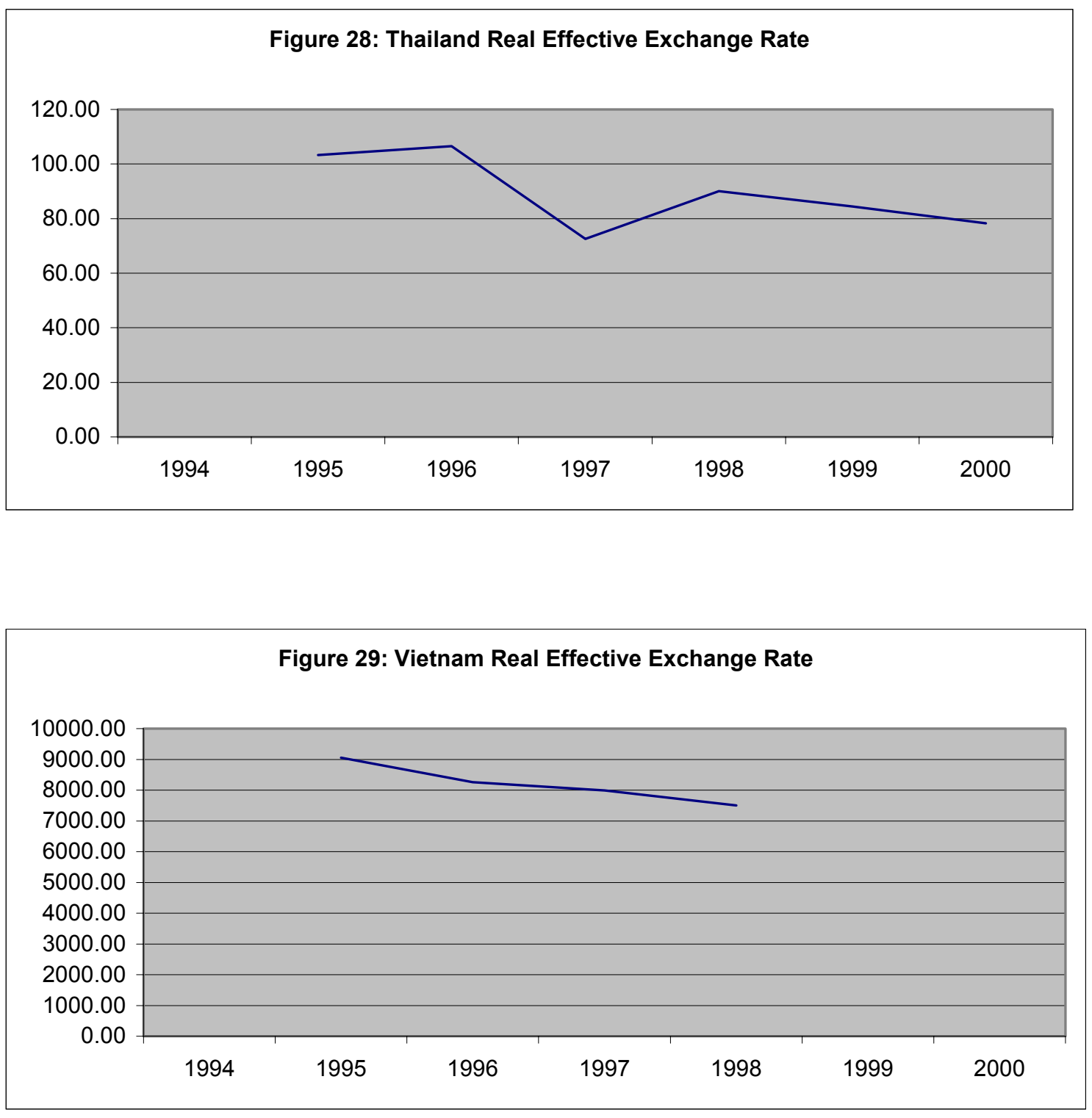

\section{International Reserves}

Financial and currency crises are often associated with heavy speculation and declining international reserves in the course of the defense of the exchange rates by authorities.

Of course, several useful indicators may be constructed from international reserves data. For instance, reserves as function of import cover or short-term liabilities over reserves could also be possible indicators. 
Table 21: International Reserves (Mn US\$)

\begin{tabular}{lrrrrrrr}
\hline \multicolumn{1}{c}{ Country } & $\mathbf{1 9 9 4}$ & $\mathbf{1 9 9 5}$ & $\mathbf{1 9 9 6}$ & $\mathbf{1 9 9 7}$ & $\mathbf{1 9 9 8}$ & $\mathbf{1 9 9 9}$ & $\mathbf{2 0 0 0}$ \\
\hline Fiji & 273.11 & 348.65 & 426.74 & 360.12 & 385.03 & 420.70 & 410.90 \\
Indonesia & & & 19125.00 & 17427.20 & 23761.90 & 27053.60 & 29393.70 \\
Philippines & & & 11745.08 & 8767.69 & 10806.24 & 15023.98 & \\
Taipei, China & 7121.78 & 7762.17 & & & & & \\
Thailand (minus gold) & & 95911.00 & 93594.00 & 88186.00 & 95084.00 & 111061.00 & \\
Viet Nam & & 36063.80 & 37810.20 & 26254.40 & 28824.70 & 34062.50 & 32016.10 \\
& & 1375.00 & 1797.00 & 2085.00 & 2097.00 & 3421.00 & 3562.00 \\
\hline
\end{tabular}

Source: Country Metadata and ADD Website

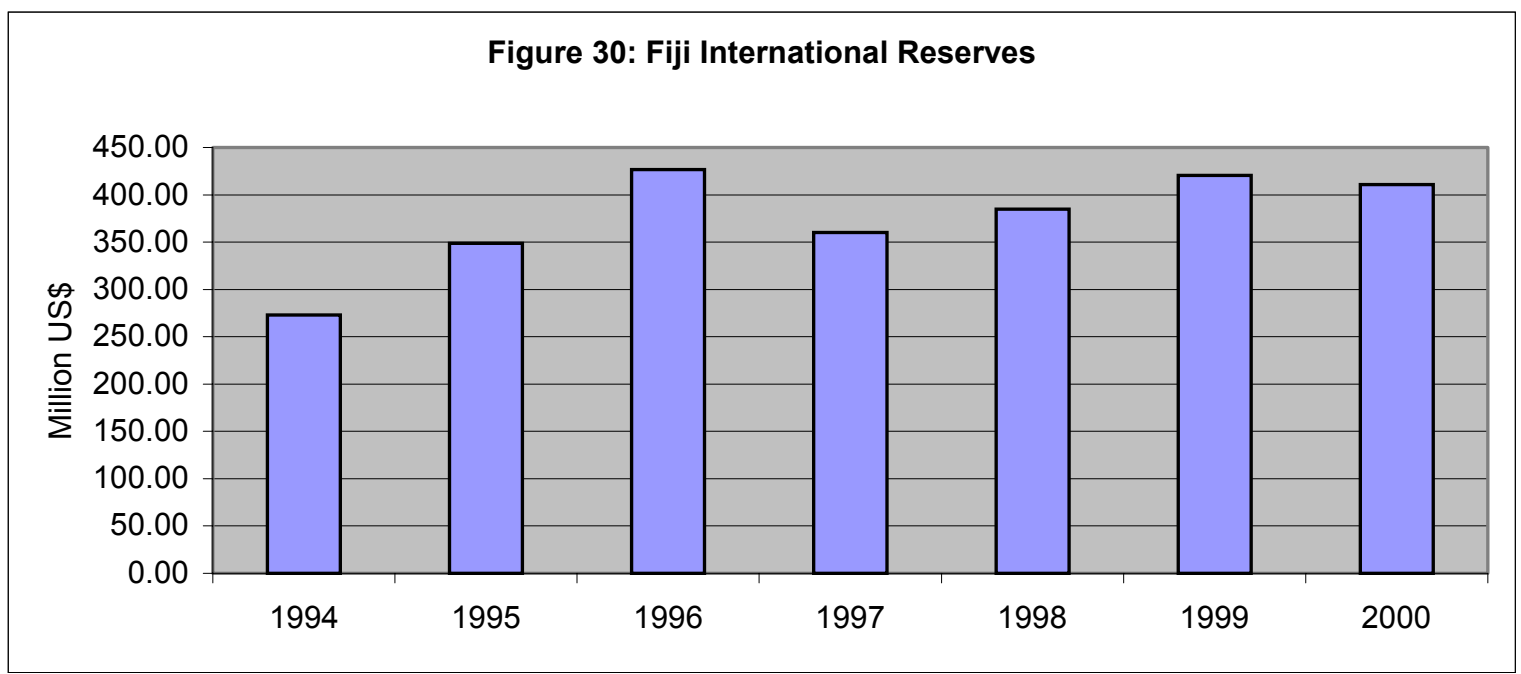



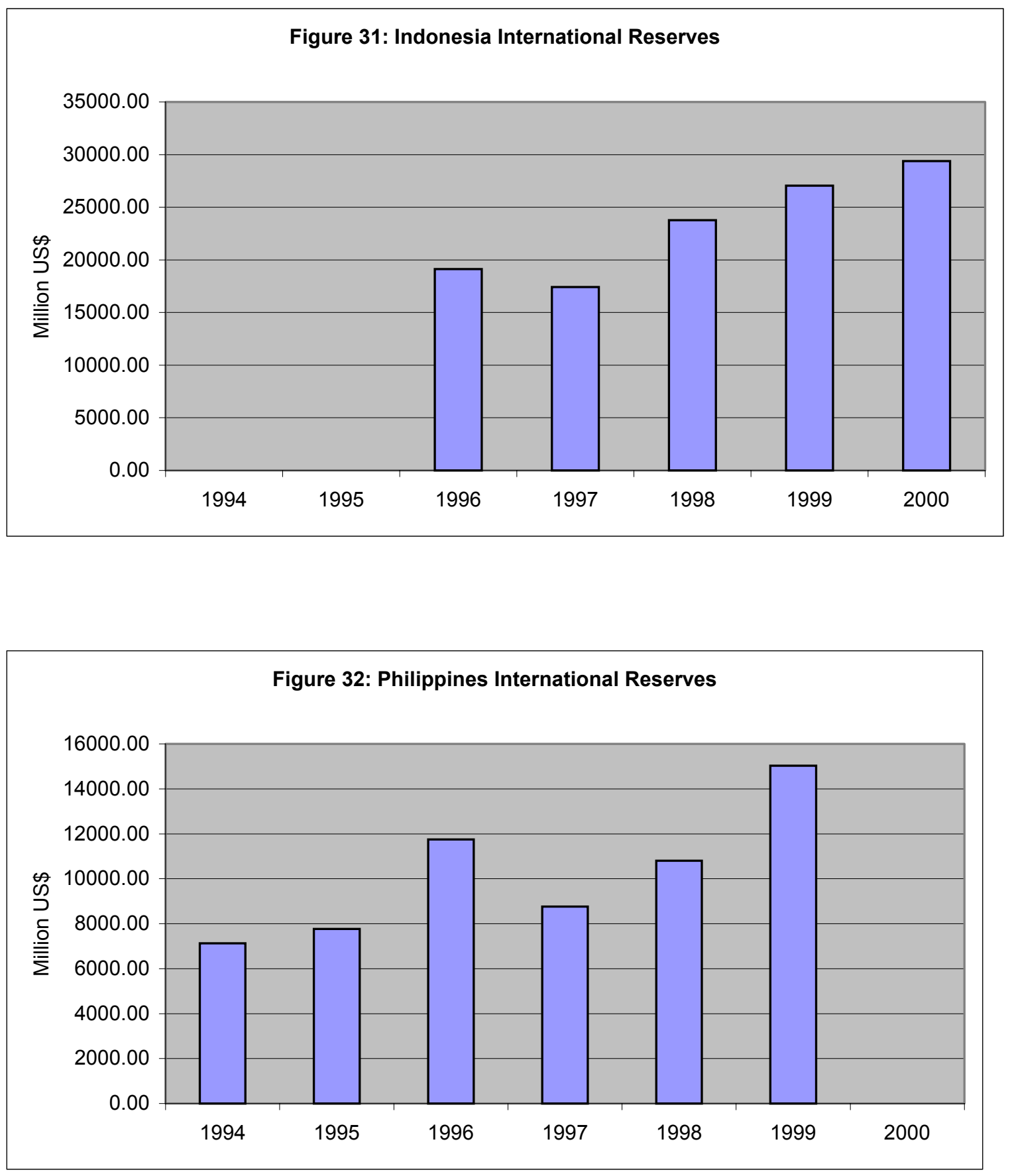


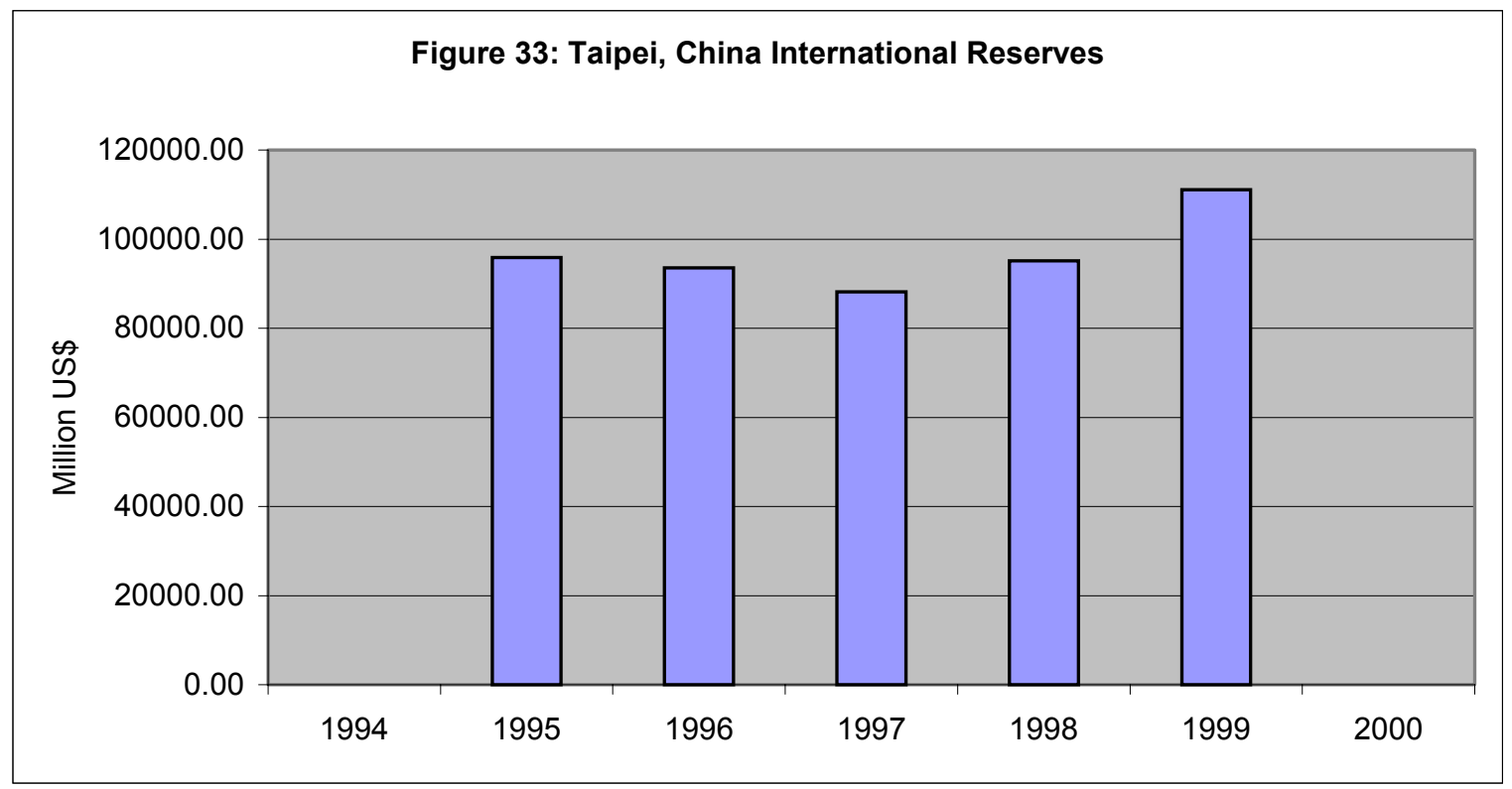

Figure 34: Thailand International Reserves (minus gold)

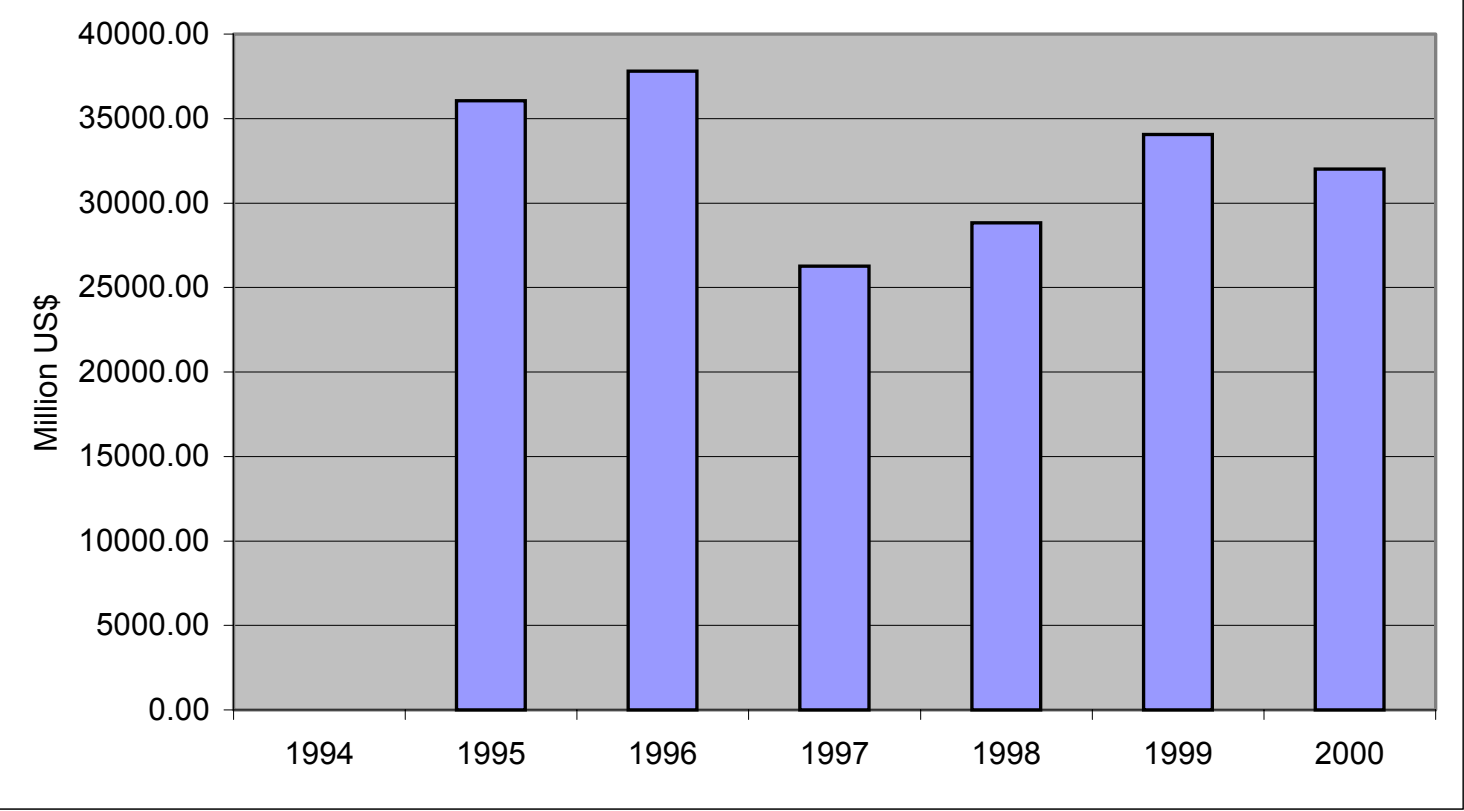




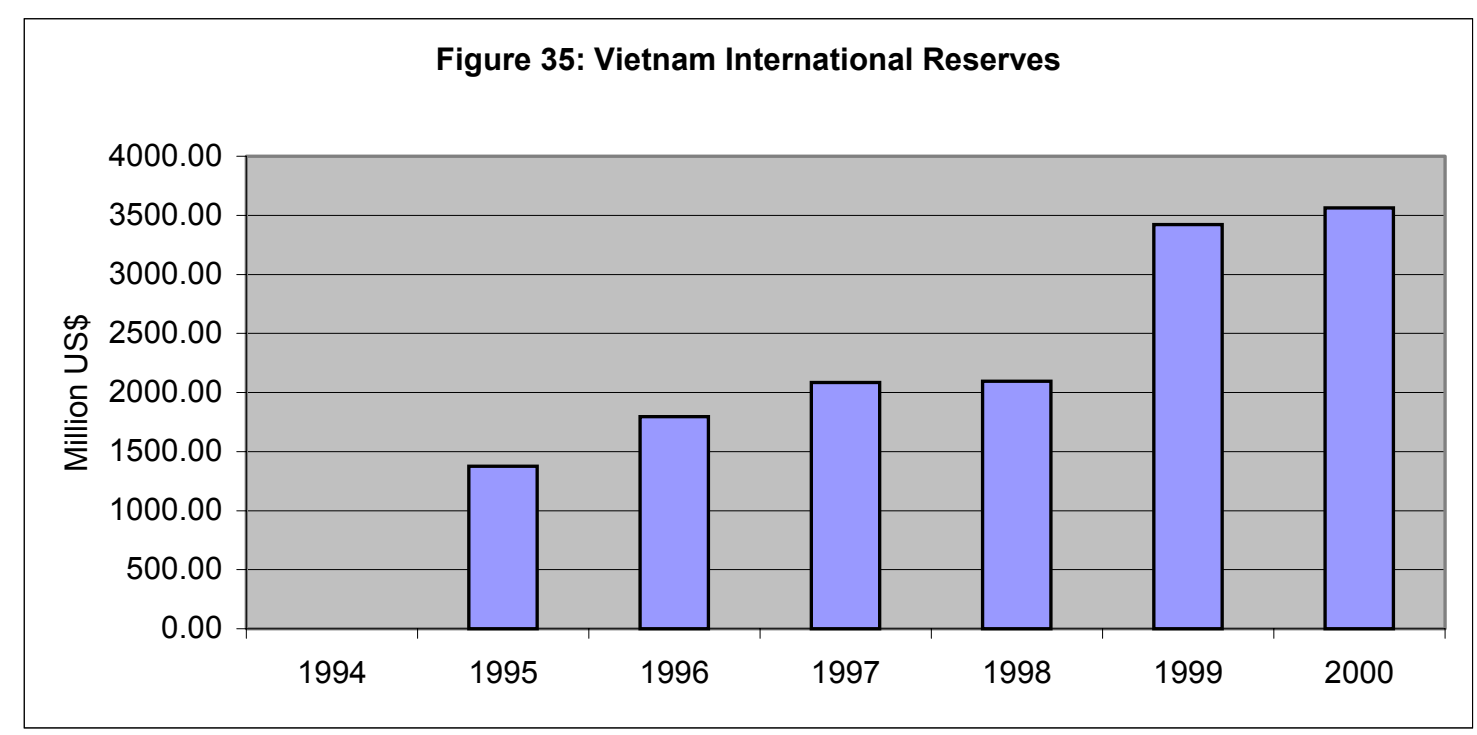

\section{Time-series Analysis on Thailand's Quarterly and Annual Leading MPIs}

In this section, a time series analysis, namely, correlation, mean and standard deviation analysis of the core set of leading indicators of Thailand will be performed to study the relationship among these indicators and their statistical behavior. Under ADB's technical assistance project, RETA 5869, monthly, quarterly and annual data for selected countries are posted in ADB website as supplied by central banks. As Bank of Thailand is regularly sending quarterly data to ADB's website, a time-series analysis on annual and quarterly data of Thailand's core MPIs will be performed for the period 19942002. This analysis may help in further streamlining the core set of indicators and to explore an approach for constructing composite indicators and threshold values or benchmark for individual series which can be used to obtain early warning signal of vulnerabilty.

Pair-wise correlation is taken on the core set of MPIs to determine which among these indicators show significant link with each other. This will exhibit the direction of movements of these indicators. Any correlation coefficient greater that 0.6 is considered significant and inclusion of both in the set may not be necessary since they give the same signal. The choice of, which among the correlated MPIs will be included in the final list, may depend on which has stronger correlation with recorded financial instability. The financial structure of the economies may also be considered, the indicators which play a more significant role in the financial system should be chosen, Data availability, including timeliness and accuracy, is also a factor.

Table 22 presents a correlation analysis of core set of MPIs of Thailand based on annual data for the period 1994-2002.

Narrow money supply M1 has a positive correlation (0.52) with stock price earning ratio only. Broad money supply has significant relationship with, in order of magnitude, International Borrowings (0.95), Credit to public sector $(-0.94)$, Total loans (0.89), Growth of domestic credit (0.84), real estate loan (0.81), M3 Growth (0.08), composite stock price index (0.64) and foreign share in trading (0.54). 
On the other hand, broad money supply $\mathrm{M} 3$ has strong relationship with composite stock price index (0.88), market capitalization of stock market (0.79), international borrowings $(0.78)$, stock price earning ratio $(0.69)$, credit to public sector $(-0.61)$, and real effective exchange rate $(0.57)$.

In terms of banking indicators, growth of domestic credit has exhibited strong relationship with credit to private sector $(0.97)$, credit to public sector $(-0.84)$, real effective exchange rate, International borrowing (0.81), total loans (0.78), real estate loans (0.66) and composite stock price index (0.55). On the other hand, credit to public sector has witnessed a significant negative relationship with International borrowings ($0.96)$, total loans $(-0.94)$, real effective exchange rate $(-0.94)$, real estate loans and composite stock price index $(-0.66)$. Credit to private sector has exhibited strong relationship with foreign share in trading (0.85), net profits of banking sector $(-0.82)$, international reserves $(-0.73)$, total loans $(0.64)$.

Table 23 shows the correlation of the core set of MPIs using quarterly data. M2 growth shows significant correlation with M3 growth (0.66), growth of domestic credit (0.54), real estate loans (0.71), total loans (0.54), and international borrowings (0.65). It is negatively correlated with public sector credit $(-0.65)$. M3 growth has shown significant correlation with real estate loans $(0.61)$ and composite stock price index (0.54).

Looking at banking indicators, we find real estate loans to be significantly correlated with $\mathrm{M} 2$ and $\mathrm{M} 3$ growth, $(0.71$ and 0.61 , respectively), growth of domestic credit (0.65), total loans $(0.91)$, international borrowings $(0.92)$, foreign share in trading (0.53), composite stock price index (0.89), market capitalization (0.82), stock price earnings ratio $(0.86)$ and real effective exchange rate $(0.86)$. It is negatively correlated with credit to the public sector $(-0.9)$

Comparing the quarterly results with annual results, we find that the correlated variables are almost the same for annual and quarterly data, the results affirm the relation between the indicators.

The core set of leading indicators can be further streamlined by removing a few variables which are highly correlated with some important MPIs. In terms of forming a composite indicator, some of the important MPIs which are not highly correlated (less than 0.60 ) with each others can be used to form a composite indicator. The geometric mean or arithmetic mean of selected indicators with equal or unequal weights can be used for constructing an appropriate composite indicator. Each country needs to perform required simulation analysis to arrive at the most appropriate composite indicator.

A volatility analysis in terms of mean, standard deviation, and coefficient of variation analysis was also conducted for both annual and quarterly data from Thailand. In constructing early warning system, the mean and standard deviation can be used to set up thresholds or benchmarks that will determine whether indicators are signaling or not. If no statistical model is implemented, one can use the standard deviation and coefficient of variation to look at the volatility of the indicators. Apart from looking applying a trend analysis, we may look at whether the current trend being exhibited has added volatility to the series and therefore may be considered a warning. 


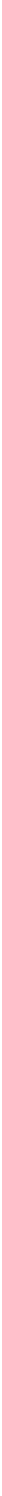


Table23. Correlation

Analysis of Leading

Indicators of

Thailand(Quarterly Data)
Central Credit Credit :Credit

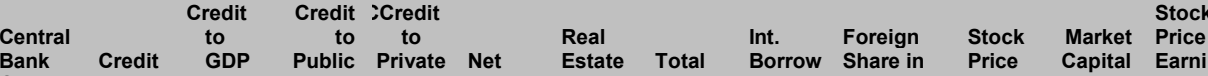

Loans Loans ing Trading Index ization g Ratio Rachange Int.

Money and Credit

M1 Growth (\% Difference From previous period)

Mrowth (\% Difference From previous period

M3 Growth (\% Difference From previous period

Central Bank Credit to the Banking System (Bn Nat. Currency Unit)

Growth of Domestic Credit (\% Difference From previous period) Domestic Credit (\% of Nominal

Credit to Public Sector (\% Nominal GDP) Credit to Private Sector (\% of Nominal GDP

\begin{tabular}{|c|c|c|c|c|c|c|c|c|c|c|c|c|c|c|c|c|c|}
\hline 1,00 & 0,21 & 0,26 & 0,09 & $-0,04$ & $-0,02$ & 0,15 & $-0,06$ & $-0,16$ & $-0,11$ & $-0,10$ & $-0,12$ & $-0,29$ & 0,00 & 0,04 & 0,04 & $-0,13$ & 0,17 \\
\hline 0,21 & 1,00 & 0,66 & $-0,12$ & 0,54 & $-0,10$ & $-0,65$ & 0,10 & 0,28 & 0,71 & 0,54 & 0,65 & 0,24 & 0,46 & 0,35 & 0,39 & 0,40 & 0,03 \\
\hline 0,26 & 0,66 & 1,00 & $-0,08$ & 0,14 & $-0,27$ & $-0,43$ & $-0,14$ & 0,19 & 0,61 & 0,36 & 0,46 & $-0,11$ & 0,54 & 0,50 & 0,50 & 0,24 & 0,12 \\
\hline 0,09 & $-0,12$ & $-0,08$ & 1,00 & $-0,18$ & 0,64 & 0,07 & 0,60 & $-0,52$ & $-0,08$ & 0,12 & $-0,15$ & 0,30 & $-0,39$ & $-0,45$ & $-0,24$ & $-0,43$ & $-0,53$ \\
\hline$-0,04$ & 0,54 & 0,14 & $-0,18$ & 1,00 & $-0,21$ & $-0,61$ & $-0,02$ & 0,14 & 0,65 & 0,57 & 0,67 & 0,29 & 0,53 & 0,45 & 0,39 & 0,55 & 0,19 \\
\hline$-0,02$ & $-0,10$ & $-0,27$ & 0,64 & $-0,21$ & 1,00 & 0,02 & 0,95 & $-0,83$ & 0,01 & 0,23 & $-0,15$ & 0,48 & $-0,51$ & $-0,56$ & $-0,26$ & $-0,30$ & $-0,70$ \\
\hline 0,15 & $-0,65$ & $-0,43$ & 0,07 & $-0,61$ & 0,02 & 1,00 & $-0,28$ & $-0,08$ & $-0,90$ & $-0,94$ & $-0,95$ & $-0,62$ & $-0,68$ & $-0,53$ & $-0,65$ & $-0,69$ & $-0,04$ \\
\hline$-0,06$ & 0,10 & $-0,14$ & 0,60 & $-0,02$ & 0,95 & $-0,28$ & 1,00 & $-0,76$ & 0,33 & 0,50 & 0,14 & 0,65 & $-0,28$ & $-0,38$ & $-0,06$ & $-0,08$ & $-0,66$ \\
\hline$-0,16$ & 0,28 & 0,19 & $-0,52$ & 0,14 & $-0,83$ & $-0,08$ & $-0,76$ & 1,00 & 0,25 & $-0,20$ & 0,13 & $-0,19$ & 0,37 & 0,38 & 0,02 & 0,25 & 0,62 \\
\hline$-0,11$ & 0,71 & 0,61 & $-0,08$ & 0,65 & 0,01 & $-0,90$ & 0,33 & 0,25 & 1,00 & 0,91 & 0,92 & 0,53 & 0,89 & 0,82 & 0,86 & 0,86 & 0,25 \\
\hline$-0,10$ & 0,54 & 0,36 & 0,12 & 0,57 & 0,23 & $-0,94$ & 0,50 & $-0,20$ & 0,91 & 1,00 & 0,90 & 0,68 & 0,62 & 0,49 & 0,67 & 0,64 & $-0,09$ \\
\hline$-0,12$ & 0,65 & 0,46 & $-0,15$ & 0,67 & $-0,15$ & $-0,95$ & 0,14 & 0,13 & 0,92 & 0,90 & 1,00 & 0,50 & 0,81 & 0,68 & 0,74 & 0,79 & 0,21 \\
\hline$-0,29$ & 0,24 & $-0,11$ & 0,30 & 0,29 & 0,48 & $-0,62$ & 0,65 & $-0,19$ & 0,53 & 0,68 & 0,50 & 1,00 & 0,04 & $-0,10$ & 0,12 & 0,35 & $-0,27$ \\
\hline 0,00 & 0,46 & 0,54 & $-0,39$ & 0,53 & $-0,51$ & $-0,68$ & $-0,28$ & 0,37 & 0,89 & 0,62 & 0,81 & 0,04 & 1,00 & 0,98 & 0,91 & 0,76 & 0,51 \\
\hline 0,04 & 0,35 & 0,50 & $-0,45$ & 0,45 & $-0,56$ & $-0,53$ & $-0,38$ & 0,38 & 0,82 & 0,49 & 0,68 & $-0,10$ & 0,98 & 1,00 & 0,90 & 0,70 & 0,57 \\
\hline 0,04 & 0,39 & 0,50 & $-0,24$ & 0,39 & $-0,26$ & $-0,65$ & $-0,06$ & 0,02 & 0,86 & 0,67 & 0,74 & 0,12 & 0,91 & 0,90 & 1,00 & 0,64 & 0,33 \\
\hline$-0,13$ & 0,40 & 0,24 & $-0,43$ & 0,55 & $-0,30$ & $-0,69$ & $-0,08$ & 0,25 & 0,86 & 0,64 & 0,79 & 0,35 & 0,76 & 0,70 & 0,64 & 1,00 & 0,49 \\
\hline 0,17 & 0,03 & 0,12 & $-0,53$ & 0,19 & $-0,70$ & $-0,04$ & $-0,66$ & 0,62 & 0,25 & $-0,09$ & 0,21 & $-0,27$ & 0,51 & 0,57 & 0,33 & 0,49 & 1,00 \\
\hline
\end{tabular}

Banking

Net Profits (as \% of Average

Real Estate Loans (\% of Tota

Total Loans (\% of Total Deposits) International Borrowings with

Maturities, One Year and Less (Mn US\$)

Stock Markets and Bonds

Foreign Share in Trading (\% of

Total Volume of Trading)

(Capital City; in National Currency

Unit)

Market Capitalization (\% of

Nominal GDP)

Stock Price Earning Ratio

Trade Exchange and

International Reserves

Real Effective Exchange Rate

International Reserves (Mn US\$),

Minus Gold

$0,17 \quad 0,03 \quad 0,12 \quad-0,53$

Based on Time-series data 1994-2002, Bank of Thailand 
Table 24 reports the mean, standard deviation, and coefficient of variation of the core indicators. The mean and standard deviation analysis of quarterly data shows that the volatility of the core indicators over the period $1994-2002$ vary from $0.3 \%(0.8 \%$ for annual data) for M1 Growth to $9.0 \%$ (8.9\% for annual data) for real estate loans. The same for annual data shows the volatility of core indicators vary from $-0.5 \%$ for net profit (as \% of average assets) to $9.5 \%$ for real effective exchange rate. The volatility of an indicator does change significantly from quarterly to annual data.

Table 24. Mean, Standard Deviation and Coefficient Of Variation for Thailand MPIs

\begin{tabular}{|c|c|c|c|c|c|c|}
\hline \multirow[b]{2}{*}{ Leading Indicators } & \multicolumn{3}{|c|}{ Annual } & \multicolumn{3}{|c|}{ Quarterly } \\
\hline & Mean & $\begin{array}{l}\text { Standard } \\
\text { Deviation }\end{array}$ & $\begin{array}{r}\text { Coefficient of } \\
\text { Variation }\end{array}$ & Mean & $\begin{array}{l}\text { Standard } \\
\text { Deviation }\end{array}$ & $\begin{array}{r}\text { Coefficient of } \\
\text { Variation }\end{array}$ \\
\hline
\end{tabular}

B. Money and Credit

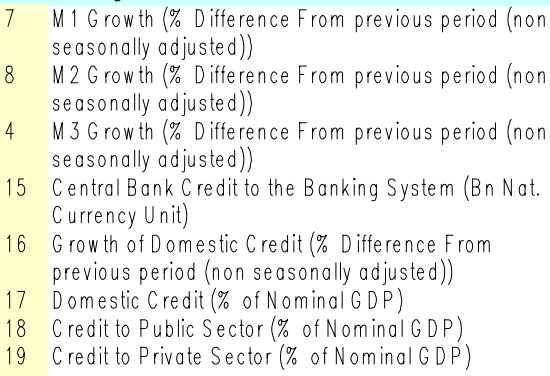


For annual data we find real effective exchange rate(9.5\%), real estate loans as $\%$ to total $(8.9 \%)$, international reserves $(7.9 \%)$, domestic credit as $\%$ of $\operatorname{GDP}(7.9 \%)$, credit to private sector as \% of GDP(7.0\%), and total loans as \% of total deposits(5.2\%), in order of magnitude, to be volatile. These results are affirmed using quarterly data. One can then expect these indicators to show more departures from the mean compared to the others but these departures may not be alarming unless it becomes more persistent and more pronounced. Volatility from mean ( coefficient of variation) can be used to construct appropriate benchmarks for giving early warnings based on individual series.

\section{Concluding Remarks}

The 1997 Asian financial crisis has revealed the limitations of the current state of monetary and financial monitoring system in most Asian countries in comprehensively addressing financial and monetary problems and issues. There is a need for better tools to monitor financial risks and vulnerabilities to prevent financial turmoil in international financial markets.

The literature survey of studies on leading indicators and various efforts by international organizations, particularly IMF carried out in this paper will be useful for the appropriate monitoring authorities of Asia-Pacific countries to build a comparable set of leading indicators for monitoring purpose.

The illustrative and simple framework for analysis and interpretation carried out in this paper highlight the usefulness of the MPIs as a tool for monitoring the vulnerabilities of financial and economic systems. However, the analysis carried out is rather limited in as much as it uses only a limited number of observation points on an annual basis. In a number of cases, it is clearly premature to attribute strong indicator properties to the series. Nevertheless, the set of 22 leading indicators, as identified by Bhattacharyay and Nerb (2002) is a good leading indicators framework for ministry of finance and central banks (or the appropriate monitoring authorities) to monitor the financial and asset markets. Of course, the development and analysis of MPI should be subject to regular review and development.

In order to improve monitoring, the timeliness of the data availability should be enhanced and monthly quarterly data would help pinpoint turning points. The timely provision of high quality data could help policymakers react to the MPI analysis in a more meaningful way. An early dissemination of crucial indicators by electronic means will help both international and domestic investors in planning and executing investments.

The most difficult part of monitoring is to analyze, interpret and translate the information contained in these indicators into something that can be construed as EWS that could help direct policy makers and decision makers to appropriate policy action. The interpretations discussed in this chapter are meant to be starting points for national authorities to develop more countryspecific monitoring schemes that take into account their specific needs and circumstances.

The interpretation of the leading MPIs is an attempt to illustrate some simple ways of analyzing the MPIs. As the data series provided by the countries participating in ADB's technical assistance project, namely RETA 5869 are not very long and are not always complete over the whole time span, it may not be appropriate at this stage to apply formal statistical methods like regression or factor analysis to identify the best candidates for a harmonized set of core MPI's. Rather, a graphical inspection of the series was chosen as a good starting point in the initial round of analysis. In the future, however, more work will have to be done in refining the MPI, specifically the core set of MPIs, and designing a more definitive framework for interpreting the MPIs. 
Further work in the interpretation of MPIs, specifically in the area of applying more formal econometric/statistical methods to identify the exact informational content of the data series can be done. In addition, at some later stage, perhaps multivariate analysis can be used to estimate the joint impact of different subsets of indicators for explaining and forecasting banking and currency crises. Another important task is to provide the analytical groundwork in devising the appropriate benchmarks or critical values for higher frequency data.

Further work on understanding the intrinsic financial structure of individual country financial systems can be undertaken. As yet, it is not advisable to compare the performance of countries solely based on MPIs. The definitions of some MPIs may vary from one country to another. At the same time, each country has its own set of frameworks, standards and regulations. Thus, the interpretation and analysis of MPIs should take into account the specific characteristics of the financial market of the concerned country. An understanding of the intrinsic and changing financial nature/structure of each country, therefore, will contribute to better assessments of the situation of a country. One important use of MPIs is to use warning signals provided by MPIs to direct focused attention to particular issues or problems and to determine whether the signal is unwarranted, stems from institutional or structural changes, or is a cause for concern.

Efforts can direct towards enhancing the early warning capabilities of the MPIs. Recall that the effectiveness of MPIs in predicting events and taking corrective measures relies heavily on the quality and timeliness of data. Hence, countries need to ensure that data satisfy set standards. Countries should also undertake extensive analysis of available qualitative and quantitative data to enable them to assess the capability and strength of the indicators in providing early signs of weakness. The indicators could be classified into leading, coincident and lagging indicators based on the results of time series analysis. There is, however, a wide scope for refining the tests for the leading, coincident and lagging indicators.

One of the distinguishing features of the leading ADB MPIs, as discussed in this paper, is the inclusion of information gleaned from Business Tendency Surveys( BTS). The use of BTS within the framework of MPI is quite unique in the literature on MPIs. The main reason for incorporating BTS information as part of the MPIs is due to the ability of BTS to capture current and future profitability trends in the corporate sector. Precisely because expectations can play an important role in the business cycle, it can have a significant influence on investments, output and employment. In as much as the health of the financial sector is tied up with developments in the real sector, e.g., the effect of the profitability in the corporate sector on the loan portfolios of banks. More importantly, since BTS are by nature forward looking, the information they convey can augment the early warning capabilities of the conventional quantitative MPIs.

The volatility analysis in terms of coefficient of variation quarterly and annual data on Thailand's core set of leading MPIs shows that real effective exchange rate, real estate loans as $\%$ to total, international reserves, domestic credit as \% of GDP, credit to private sector as \% of GDP, and total loans as \% of total deposits, in order of magnitude, to be volatile. These results are affirmed using quarterly data. One can then expect these indicators to show more departures from the mean compared to the others but these departures may not be alarming unless it becomes more persistent and more pronounced. Volatility from mean (coefficient of variation) can be used to construct appropriate benchmarks for giving early warnings based on individual series. 
The correlation analysis on quarterly and annual data on Thailand's core set of leading MPIs for the period 1994-2002 shows that the core set can be further streamlined by removing a few MPIs which are highly correlated with some key indicators. In terms of forming a composite indicator, some of the important MPIs which are not highly correlated to each others can be used to form an appropriate composite indicator. The geometric mean or arithmetic mean of selected indicators with equal or unequal weights can be used for constructing an appropriate composite indicator. Each country needs to perform required simulation analysis to arrive at the most appropriate composite indicator.

In order to develop a composite indicator, countries need to explore the compilation of a composite indicators based on a set of core leading indicators. However, caution has to be exercised so that possible misleading results are avoided. After having gained more experience with these indicators, a thorough revision should take place which might lead to some modifications of the set of core indicators. This evaluation process must also draw on the experiences with indicators and EWSs developed by the IMF, ADB, European Central Bank, BIS, and other authorities.

Another further step that can be taken is to expand the sample size of the study and compare the performance of the MPIs during other periods of financial instability. The core set of indicators may be revised accordingly to include only those which show the most consistent performance.

Finally, the scope of capacity building in monitoring is still wide among Asia-Pacifc developing countries. Technical training should be provided to Ministry of Finance, Central Banks and other relevant supervisory authorities personnel to enable them to perform meaningful interpretation and analysis of MPIs. Effective monitoring calls for a high degree of experience in analyzing the quantitative MPIs coupled with informed judgment on the adequacy of the institutional and regulatory framework of the concerned country. This will have a catalytic role in focusing attention of the relevant agencies among the Asia-Pacific countries on the role of MPIs in fostering solid, stable and efficient financial and economic systems. 


\section{References:}

Berg, A. and Pattillo, C., 1999b, "Predicting Currency Crises: The Indicators Approach and an Alternative", Journal of International Money and Finance; 18(4), August 1999, pp. 561-86.

Berg, A. and Pattillo, C., 1999a, "Are Currency Crises Predictable? A Test", IMF Staff Papers; 46(2), June 1999, pp. 107-38.

Barnhill, T. M., Pappanagiotou, P., and Schumaker, L, "Measuring Integrated Market and Credit Risks in Bank Portfolio: An Application to a Set of Hypothetical Banks Operating in South Africa, " IMF Working Paper 00/212, Washington D. C., International Monetary Fund 2000.

Bhattacharyay, B., 2001,"Strengthening and Harmonization of MPIs for monitoring financial asset markets in Asia and Pacific", presented at the concluding workshop of Regional Technical Assistance 5869, Manila, Asian Development Bank,16-18 May 2001.

Bhattacharyay, B., Nerb, G., "Leading Indicators for Monitoring the Stability of Asset and Financial Markets in the Asia and Pacific", Asia Pacific Development Journal, Vol. 9, No. 2, UN ESCAP, Bangkok, December, 2002.

Bussiere, M. and Fratzscher, M., "Towards a New Early Warning System of Financial Crises", Working Paper No. 145, European Central Bank, May 2002.

Crockett, A. "Strengthening International Economic Co-operation: The Role of Indicators in Multilateral Surveillance". IMF Working Papers No. 76, International Monetary Fund, 1987.

Corsetti, G., Pesenti, P. and Roubini N. (1999) "What Caused the Asian Currency and Financial Crisis?" Japan and the World Economy, September 1999.

Davis, E. Phillip, "Financial data needs for macroprudential surveillance - What are the key indicators of risks to domestic financial stability?", Centre for Central Banking Studies, Bank of England, 1999.

Eichengreen, B., Rose, A., and Wyplosz, C. 1995, "Exchange Market Mayhem: The Antecedents and Aftermaths of Speculative Attacks", Economic Policy, 21, pp. 249-312.

Evans, O., Leone, A., Gill, M. and Hilbers, P., "Macroprudential Indicators of Financial System Soundness", IMF Occasional Paper, 192, IMF, 2000.

Frankel, J. and Rose, A., 1996, "Currency Crashes in emerging Markets: an Empirical Treatment", Journal of International Economics, 41, pp. 351-66.

Goldstein, M., Kaminsky, G. and Reinhart, C., Assessing Financial Vulnerability, An Early Warning System for Emerging Markets, June 2000, Institute for International Economics. 
Hardy, Ddaniel, C., Pazarbasiouglu, Ceyla, "Leading Indicators of Banking Crisis: Was Asia Different?", IMF Working Paper 98/91, IMF, Washington D. C., 1998

IMF, World Economic Outlook, May, 1998

IMF . Macroprudential Analysis: Selected Aspects Background Paper. June 7, 2001.

IMF, "Financial Sector Assessment Program (FSAP): A Review : Lessons from the Pilot and Issues Going Forward, Available via the internet http:// www. Imf.org/np/fsap/2001/review.htm, IMF, Washington, D. C., 2001b.

Kaminsky, G. and Reinhart, C., The Twin Crises: Causes of Banking and Balance -ofPayments- Problems, mimeo, Board of Governors of the Federal Reserve, Washington, D. C., September 1996.

Kaminsky, G. and Reinhart, C., "Financial Crises in Asia and Latin America: Then and Now", American Economic Review, Papers and Proceedings; 88(2), May 1998, pp. 44448, 1998.

Kaminsky, G. and Reinhart, C., "The Twin Crises: The Causes of Banking and Balanceof-Payments Problems", American Economic Review; 89(3), , pp. 473-500, June 1999.

Kaminsky, G. and Reinhart, C. 2000, "On Crises, Contagion, and Confusion"; Journal of International Economics; 51(1), pp. 145-68, June 2000.

Kaminsky, G., Lizondo, S. and Reinhart, C., "Leading Indicators of Currency Crises", IMF Staff Papers, 45, No. 1, pp. 1-48, 1998.

Krugman, P. "A Model of Balance of Payments Crises". Journal of Money Credit and Banking, 11: 311-28, 1979.

Mishkin, F., "Understanding Financial Crises: A Developing Country Perspective, Annual World Bank Conference on Development Economics", 1997.

Moreno, R. "Dealing with Currency Speculation in the Asian Pacific Basin". FRBSF Economic Letter No. 97-10, 1997.

Fama, E., "Stock Returns, Real Activity, Inflation and Money," American Economic Review, 71(4) 545-565, 1981.

Sachs, J. Tornelli, A. and Velasco, A., "Financial Crisis in Emerging Markets"' NBER Working Paper No. W5576, 1995.

Salvatore, D. "Could the Financial Crisis in East Asia Have Been Predicted?". Journal of Policy Modeling 21, no. 3: 341-47, 1999.

Schantz, B., Macroeconomic Determinants of Currency Turbulences in Emerging Markets, Deutsche Bundesbank Discussion Paer No. 3/98, Frankfurt and Main, 1998.

Schantz, B.,, The sudden Freeze of the Asian Miracle: The Role of Macroeconomic Fundamentals, Asian-Pacific Journal of Finance, (Forthcoming), 1999. 
Sundararajan, V., et. al.,"Financial Soundness Indicators: Analytical Aspects and Country Practices", IMF Occasional Paper No. 212, 2002.

United Nations Economic and Social Commission for Asia and the Pacific (UN ESCAP). Economic and Social Survey of Asia and the Pacific. New York, 2000. 


\section{CESifo Working Paper Series}

(for full list see www.cesifo.de)

950 Thomas Eichner and Rüdiger Pethig, A Microfoundation of Predator-Prey Dynamics, May 2003

951 Burkhard Heer and Bernd Süssmuth, Cold Progression and its Effects on Income Distribution, May 2003

952 Yu-Fu Chen and Michael Funke, Labour Demand in Germany: An Assessment of NonWage Labour Costs, May 2003

953 Hans Gersbach and Hans Haller, Competitive Markets, Collective Decisions and Group Formation, May 2003

954 Armin Falk, Urs Fischbacher, and Simon Gächter, Living in Two Neighborhoods Social Interactions in the LAB, May 2003

955 Margarita Katsimi, Training, Job Security and Incentive Wages, May 2003

956 Clemens Fuest, Bernd Huber, and Jack Mintz, Capital Mobility and Tax Competition: A Survey, May 2003

957 Edward Castronova, The Price of 'Man' and 'Woman': A Hedonic Pricing Model of Avatar Attributes in a Synthetic World, June 2003

958 Laura Bottazzi and Marco Da Rin, Financing Entrepreneurial Firms in Europe: Facts, Issues, and Research Agenda, June 2003

959 Bruno S. Frey and Matthias Benz, Being Independent is a Great Thing: Subjective Evaluations of Self-Employment and Hierarchy, June 2003

960 Aaron Tornell and Frank Westermann, Credit Market Imperfections in Middle Income Countries, June 2003

961 Hans-Werner Sinn and Wolfgang Ochel, Social Union, Convergence and Migration, June 2003

962 Michael P. Devereux, Measuring Taxes on Income from Capital, June 2003

963 Jakob de Haan, Jan-Egbert Sturm and Bjørn Volkerink, How to Measure the Tax Burden on Labour at the Macro-Level?, June 2003

964 Harry Grubert, The Tax Burden on Cross-Border Investment: Company Strategies and Country Responses, June 2003 
965 Kirk A. Collins and James B. Davies, Measuring Effective Tax Rates on Human Capital: Methodology and an Application to Canada, June 2003

966 W. Steven Clark, Using Micro-Data to Assess Average Tax Rates, June 2003

967 Christopher Heady, The 'Taxing Wages' Approach to Measuring the Tax Burden on Labour, June 2003

968 Michael P. Devereux and Alexander Klemm, Measuring Taxes on Income from Capital: Evidence from the UK, June 2003

969 Bernhard Eckwert and Itzhak Zilcha, The Effect of Better Information on Income Inequality, June 2003

970 Hartmut Egger and Josef Falkinger, The Role of Public Infrastructure for Firm Location and International Outsourcing, June 2003

971 Dag Morten Dalen and Trond E. Olsen, Regulatory Competition and Multi-national Banking, June 2003

972 Matthias Wrede, Tax Deductibility of Commuting Expenses and Residential Land Use with more than one Center, June 2003

973 Alessandro Cigno and Annalisa Luporini, Scholarships or Student Loans? Subsidizing Higher Education in the Presence of Moral Hazard, June 2003

974 Chang Woon Nam, Andrea Gebauer and Rüdiger Parsche, Is the Completion of EU Single Market Hindered by VAT Evasion?, June 2003

975 Michael Braulke and Giacomo Corneo, Capital Taxation May Survive in Open Economies, July 2003

976 Assar Lindbeck, An Essay on Welfare State Dynamics, July 2003

977 Henrik Jordahl and Luca Micheletto, Optimal Utilitarian Taxation and Horizontal Equity, July 2003

978 Martin D. D. Evans and Richard K. Lyons, Are Different-Currency Assets Imperfect Substitutes?, July 2003

979 Thorsten Bayindir-Upmann and Frank Stähler, Market Entry Regulation and International Competition, July 2003

980 Vivek Ghosal, Firm and Establishment Volatility: The Role of Sunk Costs, Profit Uncertainty and Technological Change, July 2003

981 Christopher A. Pissarides, Unemployment in Britain: A European Success Story, July 2003

982 Wolfgang Buchholz, Richard Cornes, and Wolfgang Peters, On the Frequency of Interior Cournot-Nash Equilibria in a Public Good Economy, July 2003 
983 Syed M. Ahsan and Panagiotis Tsigaris, Choice of Tax Base Revisited: Cash Flow vs. Prepayment Approaches to Consumption Taxation, July 2003

984 Campbell Leith and Jim Malley, A Sectoral Analysis of Price-Setting Behavior in US Manufacturing Industries, July 2003

985 Hyun Park and Apostolis Philippopoulos, Choosing Club Membership under Tax Competition and Free Riding, July 2003

986 Federico Etro, Globalization and Political Geography, July 2003

987 Dan Ariely, Axel Ockenfels and Alvin E. Roth, An Experimental Analysis of Ending Rules in Internet Auctions, July 2003

988 Paola Conconi and Carlo Perroni, Self-Enforcing International Agreements and Domestic Policy Credibility, July 2003

989 Charles B. Blankart and Christian Kirchner, The Deadlock of the EU Budget: An Economic Analysis of Ways In and Ways Out, July 2003

990 M. Hasham Pesaran and Allan Timmermann, Small Sample Properties of Forecasts from Autoregressive Models under Structural Breaks, July 2003

991 Hyun Park, Apostolis Philippopoulos and Vangelis Vassilatos, On the Optimal Size of Public Sector under Rent-Seeking competition from State Coffers, July 2003

992 Axel Ockenfels and Alvin E. Roth, Late and Multiple Bidding in Second Price Internet Auctions: Theory and Evidence Concerning Different Rules for Ending an Auction, July 2003

993 Pierre Salmon, The Assignment of Powers in an Open-ended European Union, July 2003

994 Louis N. Christofides and Chen Peng, Contract Duration and Indexation in a Period of Real and Nominal Uncertainty, July 2003

995 M. Hashem Pesaran, Til Schuermann, Björn-Jakob Treutler, and Scott M. Weiner, Macroeconomic Dynamics and Credit Risk: A Global Perspective, July 2003

996 Massimo Bordignon and Sandro Brusco, On Enhanced Cooperation, July 2003

997 David F. Bradford, Addressing the Transfer-Pricing Problem in an Origin-Basis X Tax, July 2003

998 Daniel Gros, Who Needs Foreign Banks?, July 2003

999 Wolfram Merzyn and Heinrich W. Ursprung, Voter Support for Privatizing Education: Evidence on Self-Interest and Ideology, July 2003

1000 Jo Thori Lind, Fractionalization and the Size of Government, July 2003 
1001 Daniel Friedman and Donald Wittman, Litigation with Symmetric Bargaining and TwoSided Incomplete Information, July 2003

1002 Matthew Clarke and Sardar M. N. Islam, Health Adjusted GDP (HAGDP) Measures of the Relationship Between Economic Growth, Health Outcomes and Social Welfare, July 2003

1003 Volker Grossmann, Contest for Attention in a Quality-Ladder Model of Endogenous Growth, August 2003

1004 Marcel Gérard and Joan Martens Weiner, Cross-Border Loss Offset and Formulary Apportionment: How do they affect multijurisdictional firm investment spending and interjurisdictional tax competition?, August 2003

1005 Burkhard Heer, Nonsuperneutrality of Money in the Sidrauski Model with Heterogeous Agents, August 2003

1006 V. Anton Muscatelli, Piergiovanna Natale, and Patrizio Tirelli, A Simple and Flexible Alternative to the Stability and Growth Pact Deficit Ceilings. Is it at hand?, August 2003

1007 Reto Foellmi and Josef Zweimüller, Inequality and Economic Growth: European Versus U.S. Experiences, August 2003

1008 James S. Costain and Michael Reiter, Business Cycles, Unemployment Insurance, and the Calibration of Matching Models, August 2003

1009 Marco Runkel, Optimal Contest Design when the Designer's Payoff Depends on Competitive Balance, August 2003

1010 Donald O. Parsons, Torben Tranaes and Helene Bie Lilleør, Voluntary Public Unemployment Insurance, August 2003

1011 Rüdiger Pethig and Andreas Wagener, Profit Tax Competition and Formula Apportionment, August 2003

1012 Johan Willner, Privatisation and Public Ownership in Finland, August 2003

1013 Seppo Kari and Jouko Ylä-Liedenpohja, Taxation and Valuation of International Real Investments, August 2003

1014 James Heckman, Rosa Matzkin and Lars Nesheim, Simulation and Estimation of Hedonic Models, August 2003

1015 Biswa N. Bhattacharyay, Towards a Macro-Prudential Leading Indicators Framework for Monitoring Financial Vulnerability, August 2003 